\title{
Modification of the mandibular split based on a physical model
}

\author{
Citation for published version (APA):
}

Böckmann, R. A. (2017). Modification of the mandibular split based on a physical model: experimental animal and clinical studies. [Doctoral Thesis, Maastricht University]. Datawyse / Universitaire Pers Maastricht. https://doi.org/10.26481/dis.20171207rb

Document status and date:

Published: 01/01/2017

DOI:

10.26481/dis.20171207rb

Document Version:

Publisher's PDF, also known as Version of record

\section{Please check the document version of this publication:}

- A submitted manuscript is the version of the article upon submission and before peer-review. There can be important differences between the submitted version and the official published version of record.

People interested in the research are advised to contact the author for the final version of the publication, or visit the DOI to the publisher's website.

- The final author version and the galley proof are versions of the publication after peer review.

- The final published version features the final layout of the paper including the volume, issue and page numbers.

Link to publication

\footnotetext{
General rights rights.

- You may freely distribute the URL identifying the publication in the public portal. please follow below link for the End User Agreement:

www.umlib.nl/taverne-license

Take down policy

If you believe that this document breaches copyright please contact us at:

repository@maastrichtuniversity.nl

providing details and we will investigate your claim.
}

Copyright and moral rights for the publications made accessible in the public portal are retained by the authors and/or other copyright owners and it is a condition of accessing publications that users recognise and abide by the legal requirements associated with these

- Users may download and print one copy of any publication from the public portal for the purpose of private study or research.

- You may not further distribute the material or use it for any profit-making activity or commercial gain

If the publication is distributed under the terms of Article $25 \mathrm{fa}$ of the Dutch Copyright Act, indicated by the "Taverne" license above, 


\section{Modification of the mandibular}

split based on a physical model Experimental animal and clinical studies

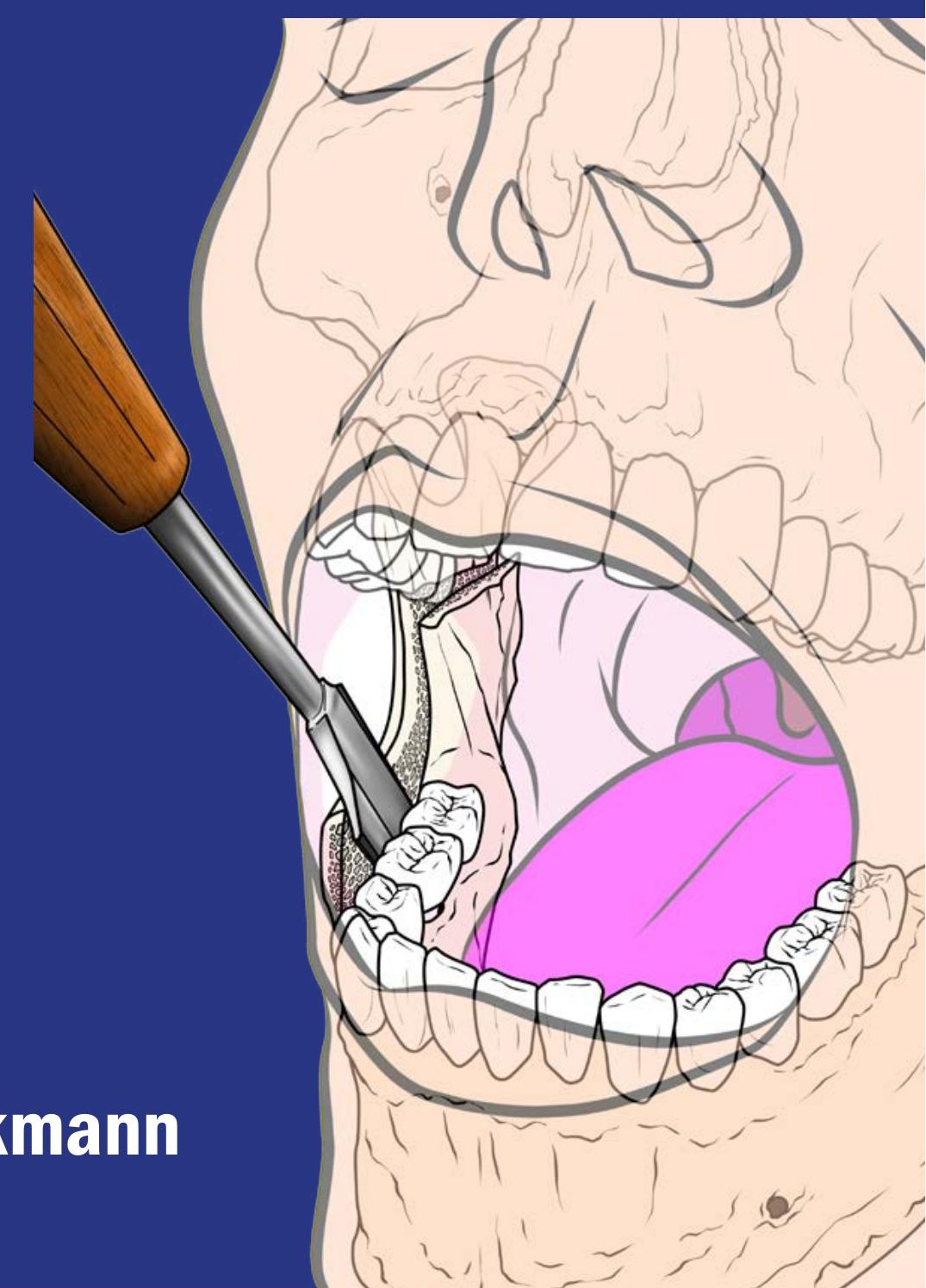


Layout: Datawyse

Cover design: Keisuke Koyama

(C) Copyright Roland Böckmann, Maastricht 2017

Production: Datawyse | Universitaire Pers Maastricht

ISBN 9789461597717

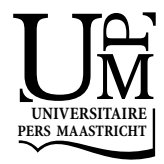




\section{Modification of the mandibular split based on a physical model}

\section{Experimental animal and clinical studies}

Proefschrift

ter verkrijging van de graad van doctor aan de Universiteit Maastricht, op gezag van de Rector Magnificus, Prof. dr. Rianne M. Letschert volgens het besluit van het College van Decanen, in het openbaar te verdedigen op donderdag 7 december 2017 om 12.00 uur

door

Roland August Böckmann 


\section{Promotor}

Prof. dr. dr. P.A.W.H. Kessler

\section{Co-promotores}

Prof. dr. dr. S. Bergé (Radboud Universiteit Nijmegen)

Prof. dr. dr. K.-D. Wolff (Technische Universität München, Germany)

\section{Beoordelingscommissie}

Prof. dr. L.W. van Rhijn (voorzitter)

Prof. dr. A.G. Becking (Universiteit van Amsterdam)

Prof. dr. A. Herrler

Prof. dr. dr. G. Swennen (Medizinische Hochschule Hannover, Germany)

Prof. dr. J.E. Wildberger 


\section{Contents}

Chapter 1 Introduction

Chapter 2 The modifications of the sagittal ramus split osteotomy: a literature review

Chapter 3 Pilot study of modification of the bilateral sagittal split osteotomy (BSSO) in pig mandibles

Chapter 4 Modification of the bilateral sagittal split osteotomy (BSSO) in a study using pig mandibles

Chapter 5 In-vitro comparison of the sagittal split osteotomy with and without inferior border osteotomy

Chapter 6 An in-vitro comparison study of the use of a drill or a saw in the Hunsuck-Dal Pont modification of the Obwegeser sagittal split osteotomy in pig mandibles

Chapter 7 Lingual fracture patterns of the mandible split in humans using the inferior border osteotomy - preliminary results

Chapter 8 Discussion and future perspectives

Valorisation Addendum

Summary

Samenvatting

Other publications

Curriculum vitae

Dankwoord 
- aan mijn ouders - 
Chapter

1

Introduction 



\section{THE HISTORY OF THE SAGITTAL SPLIT OSTEOTOMY}

The first glimpse of orthognathic surgery was taken at the City of Wheeling, West Virginia on June 12th, 1848, when Simon P. Hullihen operated for the first time on his adolescent patient Mary S. ${ }^{1}$ She suffered from an elongated chin combined with a protrusion of her mandible due to fierce scarring of her neck after severely burning her chin at the age of five. Hullihen achieved a normal occlusion and an improved appearance by repositioning the frontal mandibular dento-alveolar block, which was at the time fixated by wires and with a plate in the vestibulum and left to heal for six weeks (Fig. 1).
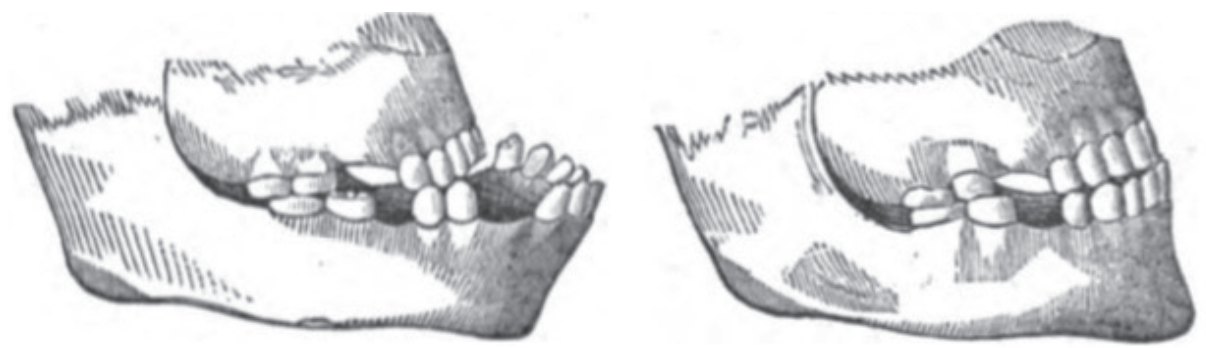

Figure 1 The first known orthognathic operation by Hullihen (1848). ${ }^{1}$

Almost 50 years later Vilray Blair, a professor of oral surgery at Washington University Dental School, set the next known step in orthognathic surgery. ${ }^{2}$ He described the protrusion of the mandible after a bilateral osteotomy of the rami in a patient with retrognathia. The ramus was cut straight with a saw using an extraoral approach (Fig. 2) resulting in a visible scarring of the cheek and neck area. Then he repositioned the fractured mandible to achieve a normal occlusion and pleasant facial appearance. The new position was secured by intermaxillary wiring and a splint made from plaster.

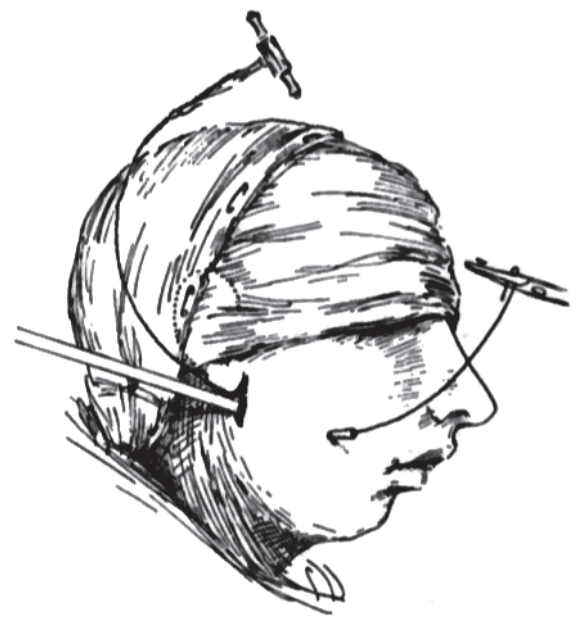

Figure 2 Osteotomy of the ascending ramus by Blair (1912). ${ }^{20}$ 
This surgical correction of the mandible is regarded by many as the first true orthognathic operation. Surprisingly, Blair advised to cut the inferior alveolar nerve (IAN) first and then the ramus just above the lingula. He considered it to be the best location to prevent non-union of the fragments. ${ }^{3}$ Blair himself was not afraid of ankylosis or damage to the IAN, but more of a relapse.

The technique of cutting the mandibular ramus using an extraoral approach was modified by Perthes, Schlössmann, Kostečka, Kazanjian and Schuchardt in the following years. At a similar time to Blair's publication, Perthes quoted a technique developed by von Eiselsberg ${ }^{4}$ to treat retrognathia in his book "Injuries and Pathology of the Jaw". The body of the mandible was cut in an S-shaped step like manner (Fig. 3) with the fragments in an end-to-end position. ${ }^{5}$ Consolidation of the fracture was achieved by maxillo-mandibular wiring. Neither in the original article ${ }^{4}$ nor in its quotation was possible damage to the IAN mentioned. Aldus Perthes, von Eiselsberg treated three patients with great success.

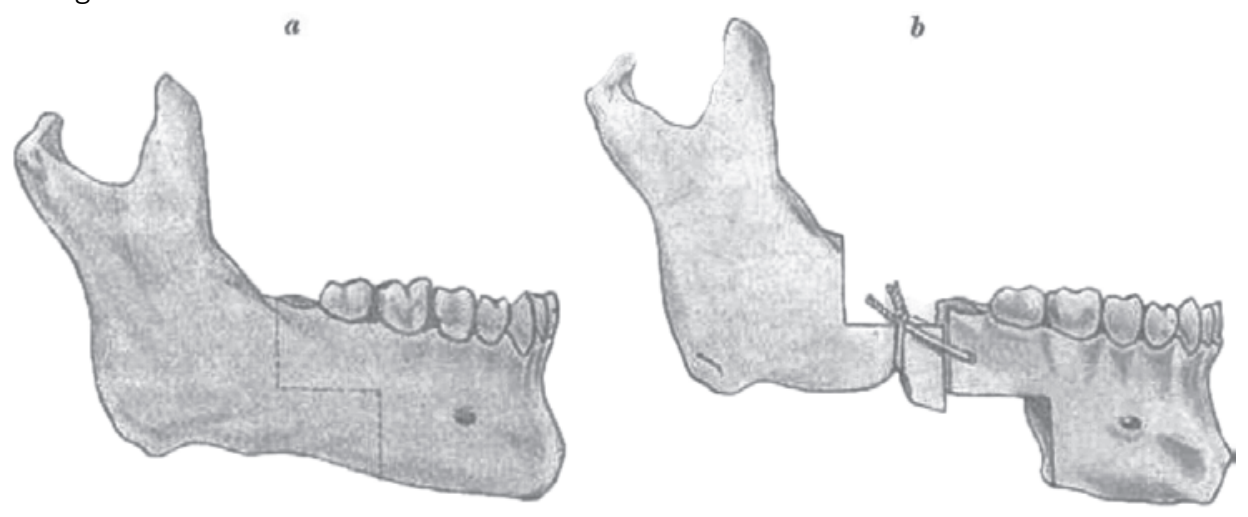

Figure 3 Osteotomy of the mandibular body according to v. Eiselsberg (1906). ${ }^{7}$

Fifteen years later Perthes published an article where he modified Blair's technique by localizing the cut of the ramus well above the lingual mandibular foramen, ${ }^{6}$ initially used by his co-worker Schlössmann, who used it to treat mal-aligned fractures of the mandible (Fig. 4). His technique is still known under the name of Perthes-Schlössmann after its presentation in the second edition of his book. ${ }^{7}$

In 1931, Kostečka reported a modification of this technique. ${ }^{8}$ Using a Gigli saw he avoided excessive visible scaring. The wire was placed with a picker blindly; such was the osteotomy (Fig. 5). Three years later he modified the direction of the osteotomy from horizontal orientation to an orientation what would be categorized as a deep condylar fracture today. ${ }^{9}$ He found this type of osteotomy especially suited to close an open bite (Fig. 6). 


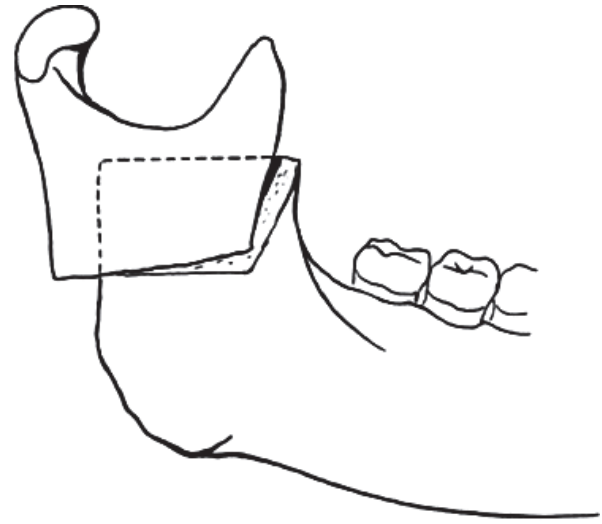

Figure 4 Osteotomy of the ascending ramus (Perthes-Schlössmann, 1922). ${ }^{7}$

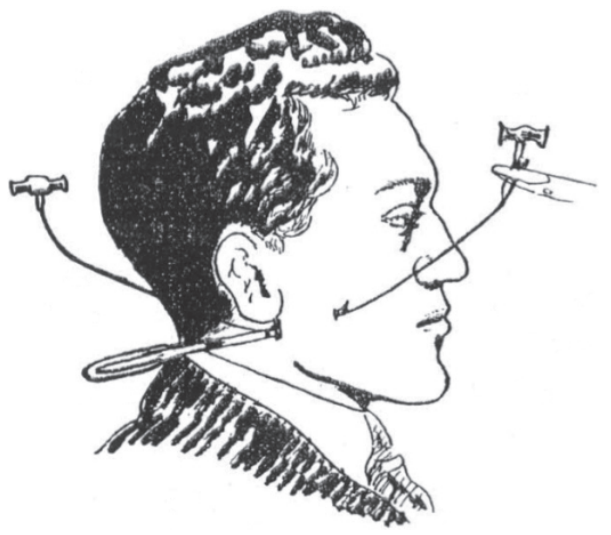

Figure 5 Osteotomy of the ascending ramus (Kostečka, 1931). ${ }^{8}$
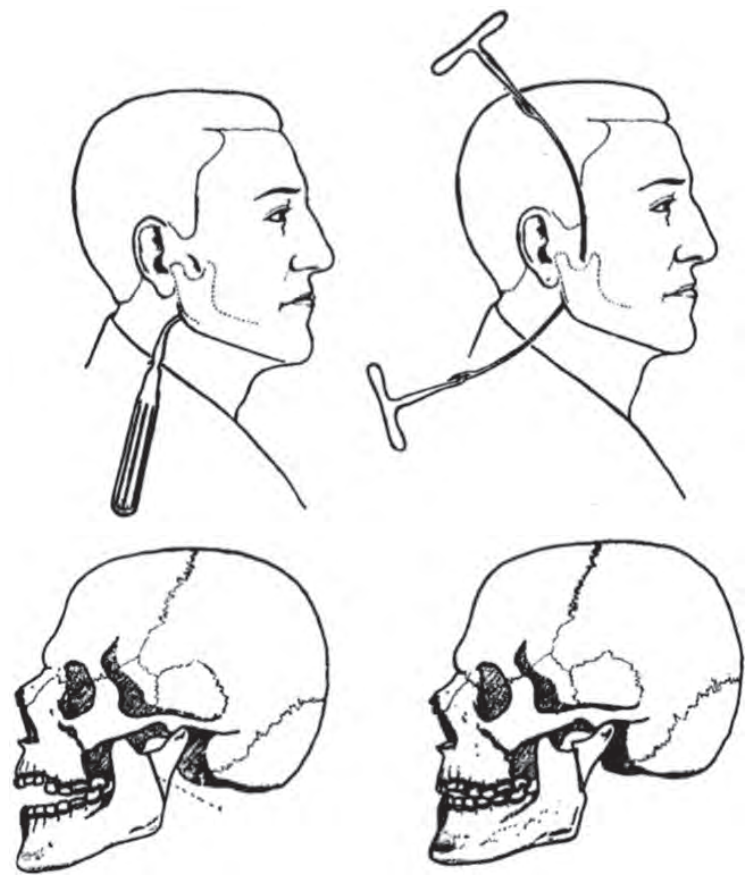

Figure 6 Modification of the ascending ramus osteotomy (Kostečka, 1934). ${ }^{9}$

The same technique was introduced by Kazanjian in the English-speaking world in 1951. ${ }^{10}$ The osteotomy of the ramus was done by chiseling, beginning from the buccal side and well above the lingula, thus preserving the inferior anterior nerve from damage (Fig. 7). 


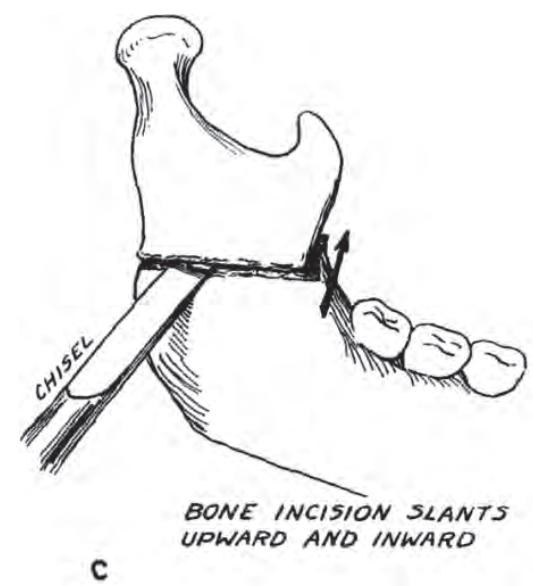

C
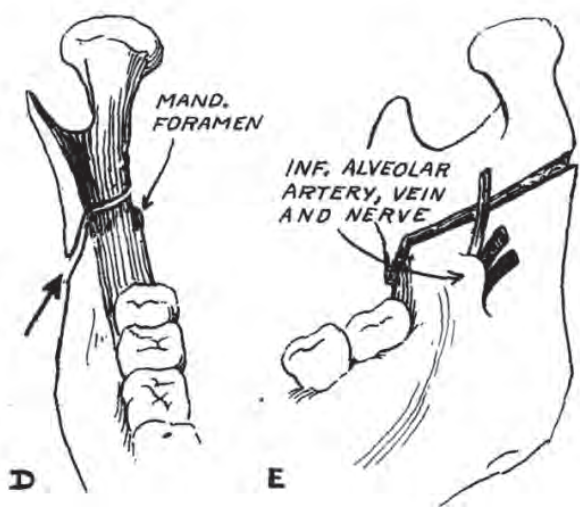

Figure 7 Osteotomy of the ramus with chisels (Kazanjian, 1951). ${ }^{10}$

Schuchardt introduced a major modification of this now established technique by adding a step to the horizontal cut. ${ }^{11}$ As a result the overlap of the segments was enlarged and rotation of the cranial segment was hampered (Fig. 8). He claimed that the whole operation could be performed more easily by only using an intraoral approach.

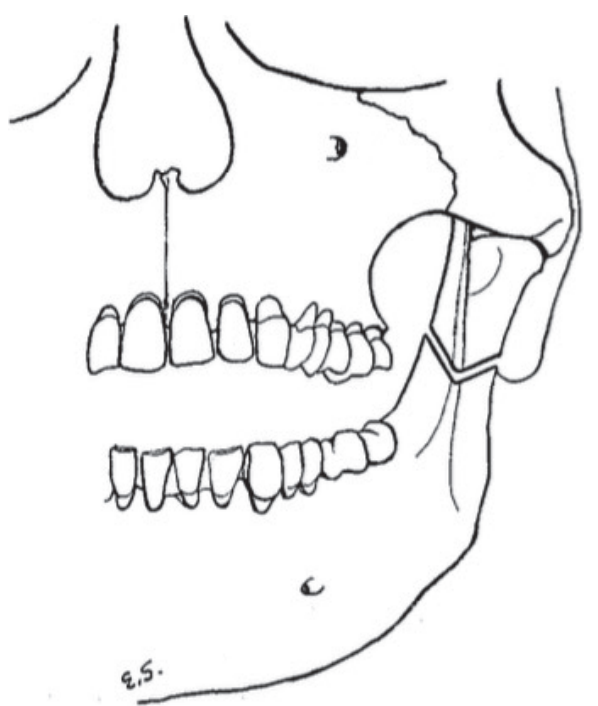

Figure 8 Schuchardt's modification of the osteotomy (1954). ${ }^{11}$

Hugo Obwegeser was not satisfied with the known techniques of mandibular osteotomies. ${ }^{12}$ He retrospectively analyzed 50 cases operated in his hospital according to the technique by Kostečka. Obwegeser found serious complications such as partial or total relapse, facial palsy or fistulas of the parotid gland in more than half of the patients. In 
his opinion the small contact area of the fragments was responsible for the high number of relapses. Bell's palsy and fistulas were related to the extraoral approach. Even the intraoral approach could not solve all the problems.

All of these disadvantages were solved by the sagittal split osteotomy ${ }^{13}$ revolutionary for the time, and which was first tested in an edentulous patient under sedation and local anesthesia in February 1953 (Fig. 9). The sagittal split went wrong.

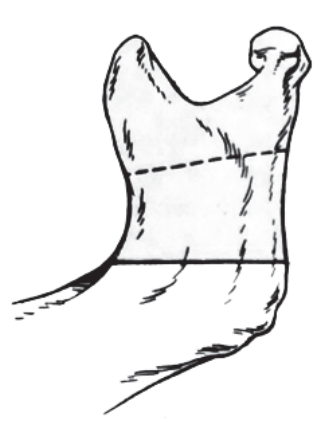

Abb. 12 .

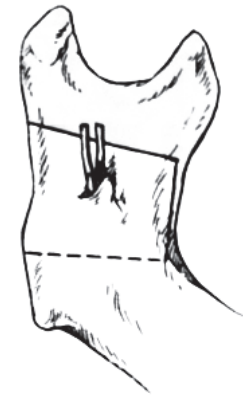

Abb. 13 .

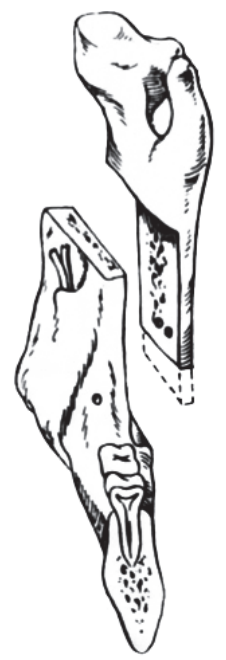

Abb. 14 .

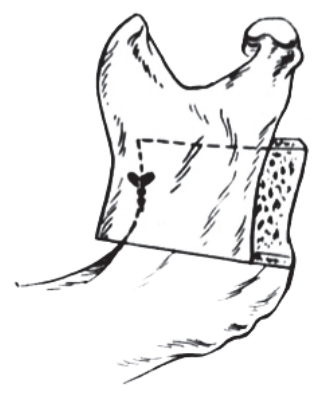

Abb. 15.

Figure 9 Sagittal split osteotomy (Obwegeser, 1955). ${ }^{13}$

The second operation took place one month later. Coincidentally Schuchardt was present as well. In place of the jigsaw Obwegeser had used in the first operation, he changed his instrument to a Lindemann burr for a better view. During the horizontal cutting he had to switch back to the saw because of a technical problem, but the rest of the osteotomies were made with the burr. This time it was a success, despite of some numbness of the lower lip that diminished over the coming year.

In the third case Obwegeser fractured the buccal cortex which then required a demanding osteosynthesis by wire. He stated a serious hematoma postoperatively, which was later absorbed without the need for secondary surgery.

The story by Obwegeser summarized meticulously all challenges a surgeon has to deal with in the sagittal split osteotomy:

- To trust his own osteotomies, which have to be suitable to function as the planed fracture lines,

- To trust that the altered anatomy will not superpose these osteotomies. 
Lack of these presumptions will force the surgeon to deepen his osteotomies and to use the chisel more than splitting the jaw with the osteotomes, thus taking more risks, such as:

- Damaging the IAN,

- Creating more bleeding and/or edema.

At the time of introducing the sagittal split osteotomy the overlapping bony segments weren't that much bigger than in the Perthes-Schlössmann procedure. This would change in the years to come. In Obwegeser's publication in $1957^{14}$ the buccal horizontal osteotomy was placed slightly towards the mandibular angle (Fig. 10) developing into a true vertical osteotomy (Fig. 11) in his article of $1964 .{ }^{15}$ To Obwegeser's annoyance his former co-worker Dal-Pont had published the idea of a true vertical osteotomy (Fig. 12) some years earlier. ${ }^{16}$

d.
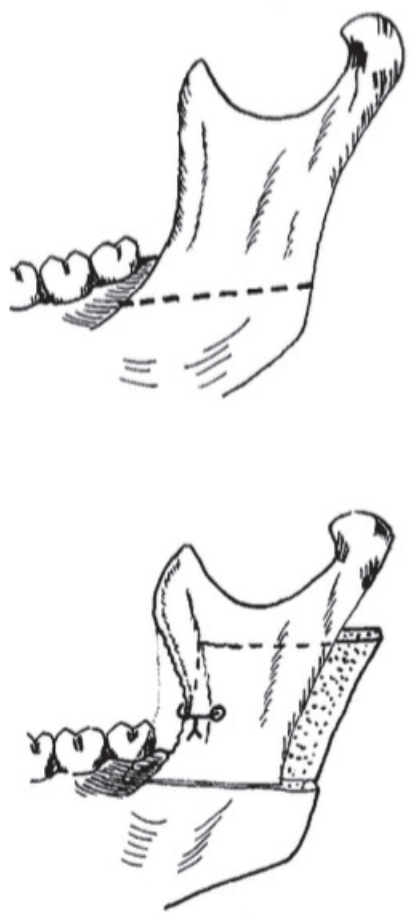

I).
B.
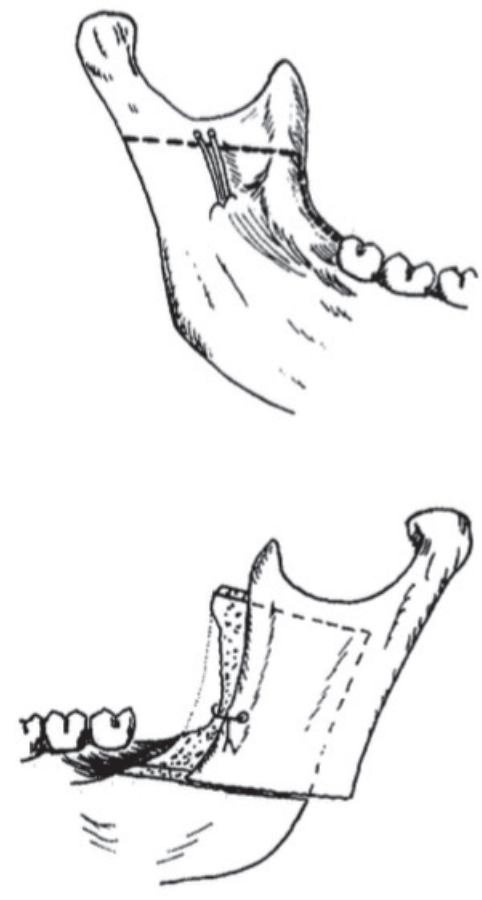

E.
C.

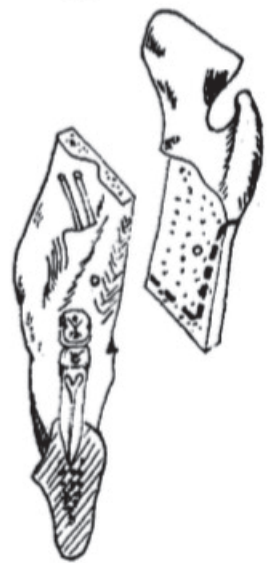

Figure 10 First modification of the BSSO (Obwegeser, 1957). ${ }^{14}$ 
Introduction
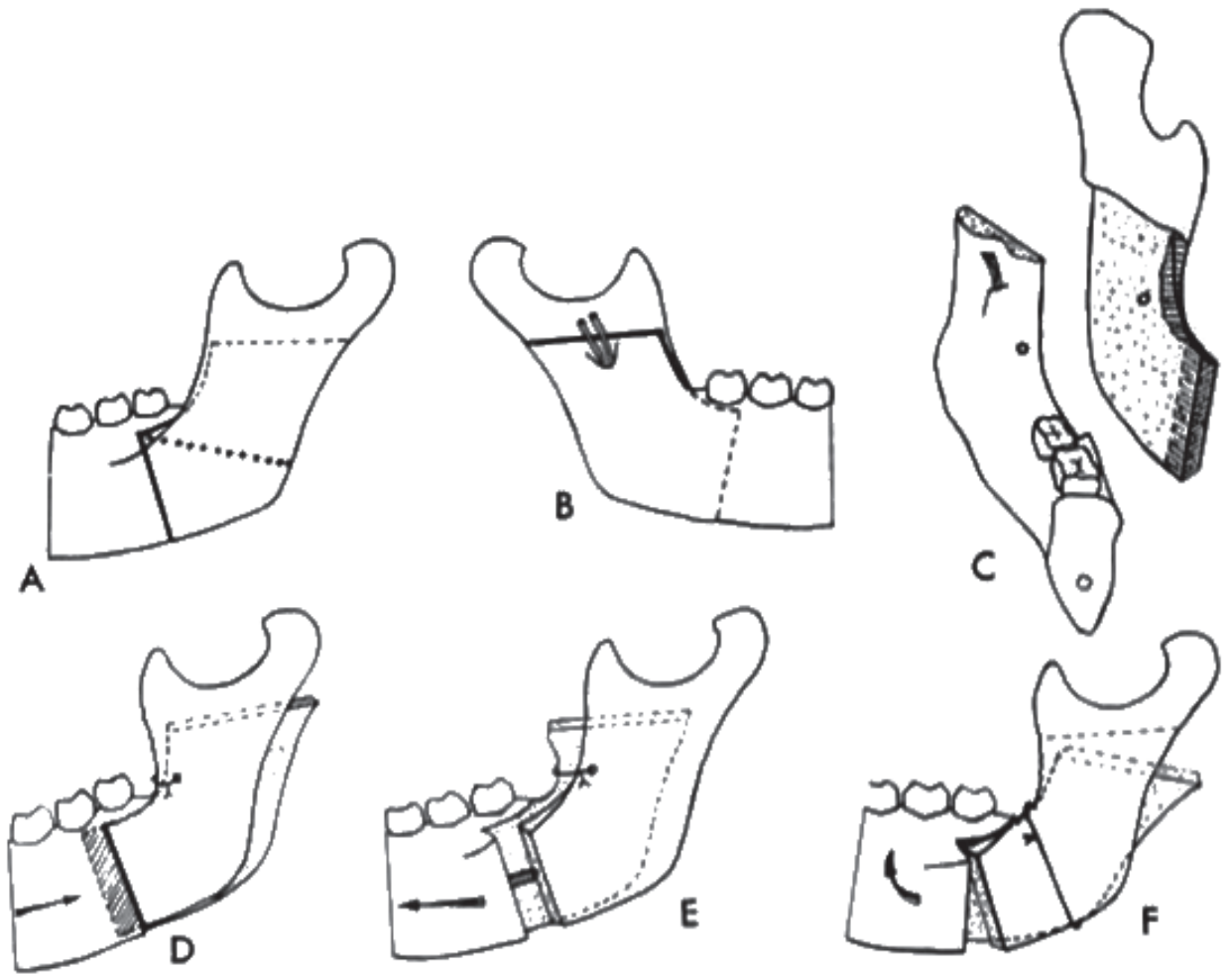

FIG. I

Figure 11 Second modification of the BSSO by Obwegeser (1964). ${ }^{15}$

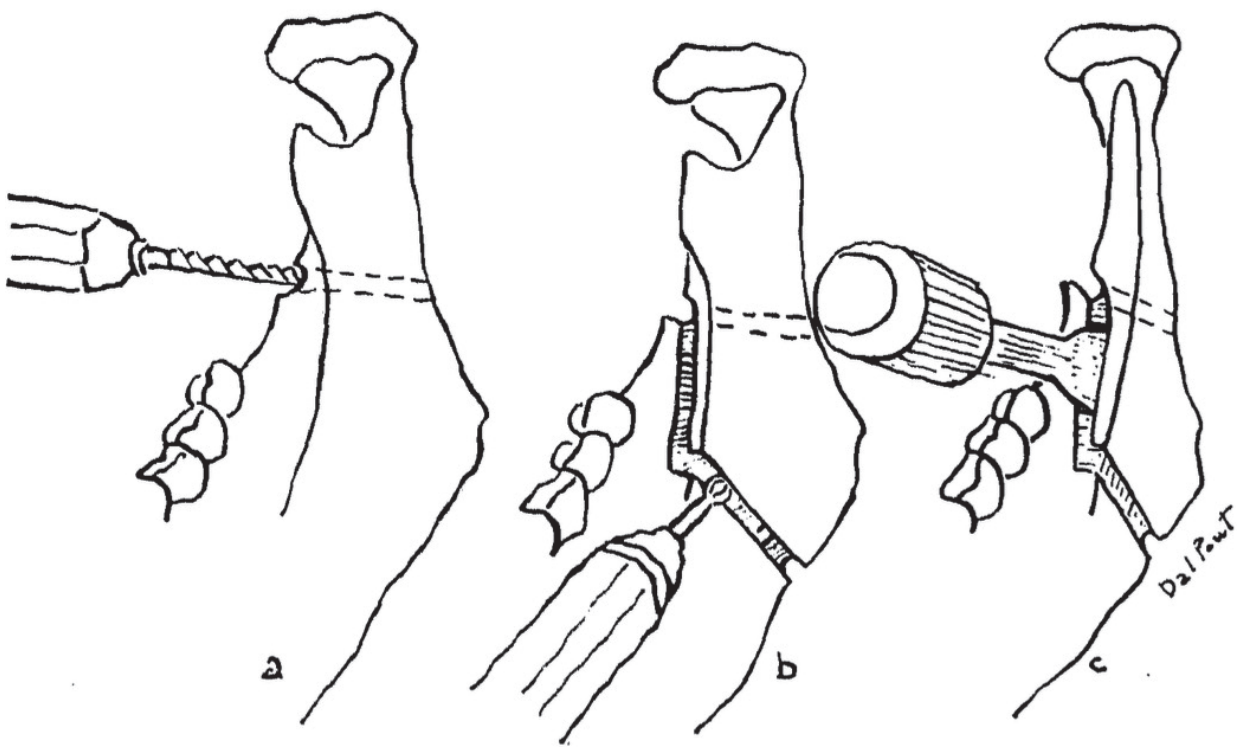

Figure 12 Modification of Obwegeser's BSSO by Dal Pont (1959). ${ }^{63}$ 
Becoming the standard technique for mandibular orthognathic surgery some problems still remained:

Cancellous bone is less voluminous around the mandibular angle and in the posterior part of the ascending ramus. Hunsuck limited the horizontal osteotomy just posterior to the lingula (Fig. 13) avoiding extensive stress to the neuro-vascular bundle. ${ }^{17}$ Furthermore he did not advocate osteosynthesis of the bony fragments at all but mandibulo-maxillary fixation. This procedure was already common at the beginning of the century with good results. ${ }^{18}$

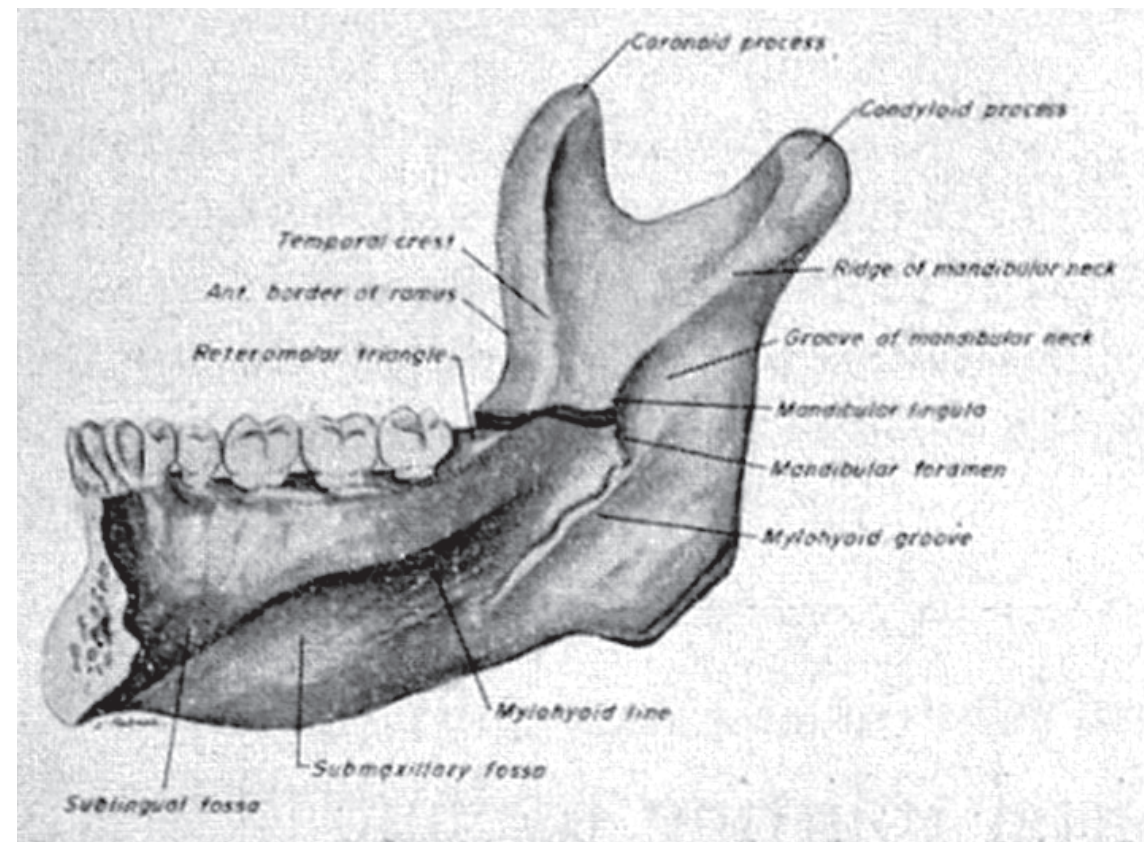

Figure 13 Hunsuck's modification of the BSSO (1968). ${ }^{17}$

Epker's modification is based on the modification of Hunsuck, being even gentler with the medial-horizontal osteotomy to protect the neurovascular bundle. Epker chose to place one wire for a semi-rigid fixation of the two fragments (Fig. 14) to control the position of the condyle, which he identified as a main reason for relapse.

In his book of 1976 "New Concepts in Maxillofacial Bone Surgery" Spiessl et al introduced the internal rigid fixation in maxillofacial surgery. ${ }^{19}$ Already being popular in general traumatology based on research by the "Arbeitgemeinschaft für Osteosynthesefragen (AO)" Spiessl and co-workers covered the treatment of mandibular fractures in 6 chapters and the osteosynthesis in orthognathic surgery in 3 chapters stressing the importance of the operation in maxillofacial surgery. Spiessl placed three lag screws around the neurovascular bundle in order to fixate the two segments against each other but also to compress them against each other permitting primary bone healing. Pri- 
mary bone healing results in complete bone healing within three weeks instead of 6 week long immobilization necessary in secondary (indirect) bone healing. Furthermore he added a small but effective modification to the sagittal split osteotomy. He removed the lingual crest of the cortical bone plate covering the oblique line in the retromolar region. This procedure facilitates a good view on the lingula as well as on the cancellous and cortical bone structures. Already in 1971 Michelet and Champy favored a fixation of the two segments by monocortical screw fixed miniplates (functional stable) opposed to the $\mathrm{AO}$ defined rigid compression osteosynthesis. This idea had been published by Blair yet in 1912 (Fig. 15) but was abandoned because of frequent infections. ${ }^{20}$ The huge advantages of the internal rigid fixation against the semi-rigid fixation by wire are fast bone healing, immediate functional recovery and decreased relapse.
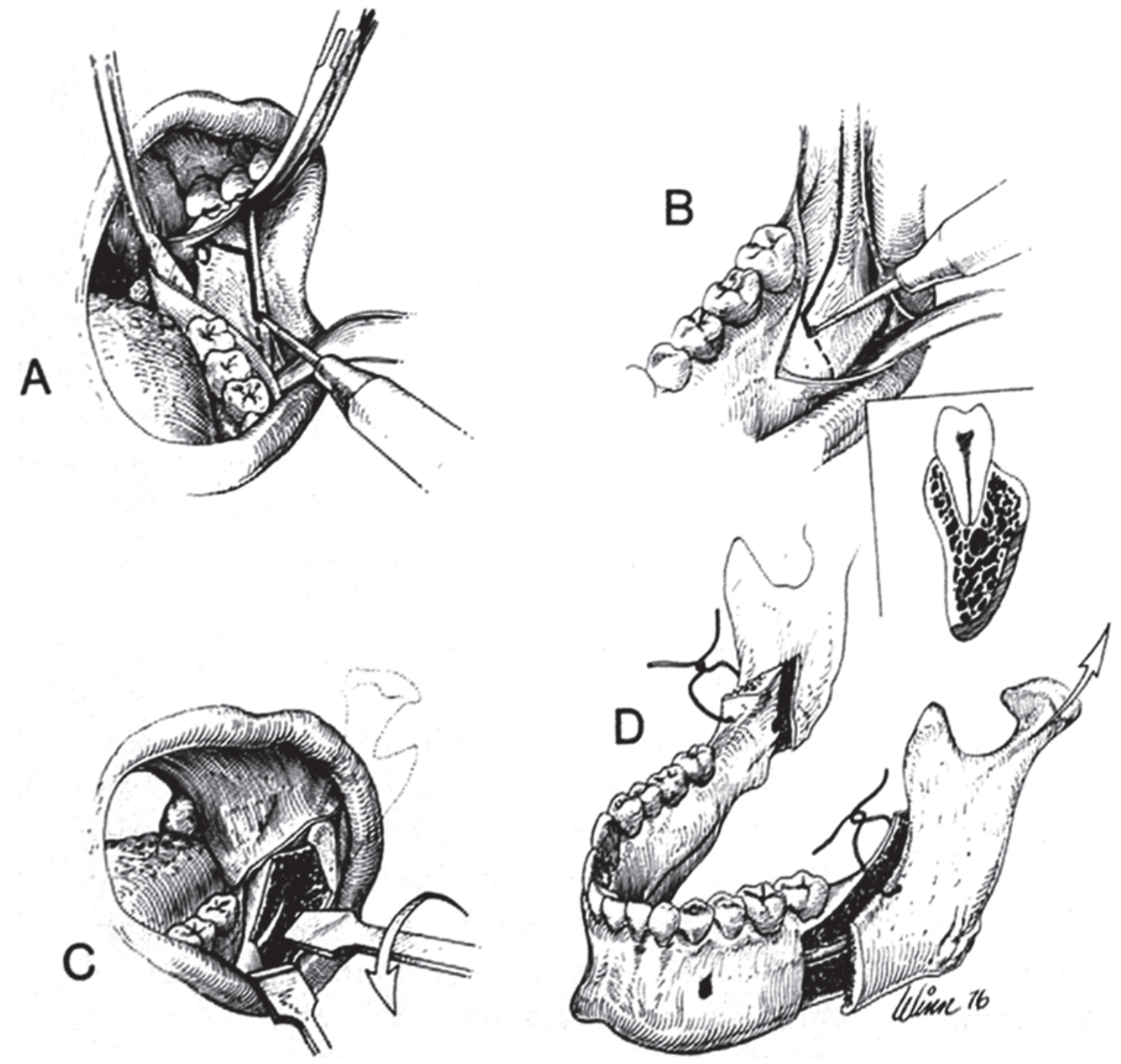

Figure 14 Modification of the BSSO by Epker (1977). ${ }^{24}$ 


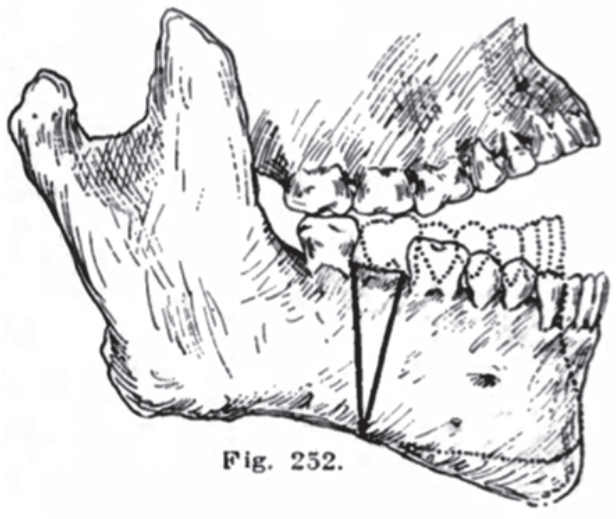

Figure 15 Osteosynthesis of the mandible (Blair, 1912). ${ }^{20}$

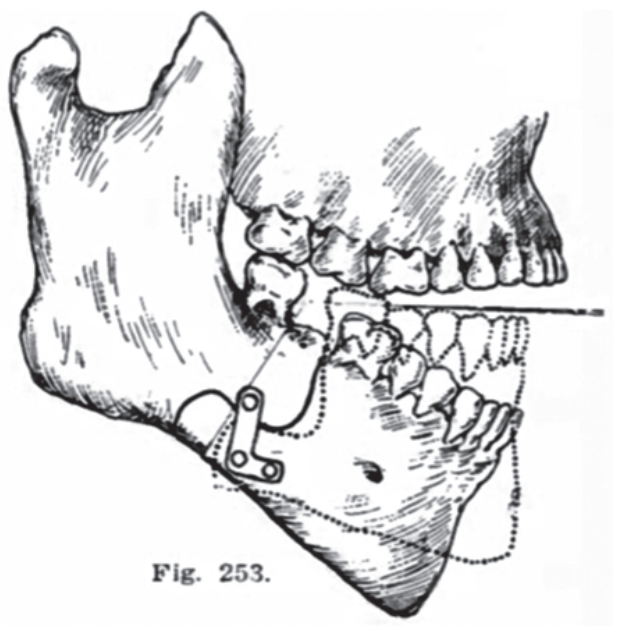

Wolford proposed the most recent change in 1990. Opposed to his predecessors he did not modify present elements of the technique but added an element: the osteotomy of the inferior mandibular border. ${ }^{21}$ Even when using the normal technique a sufficient cut of the inferior border can cause problems. Wolford constructed a special saw to ease the splitting (Fig. 16). He advised the use of the saw to the experienced surgeon only, but claims that his modification simplifies the sagittal splitting of the mandible. ${ }^{22}$

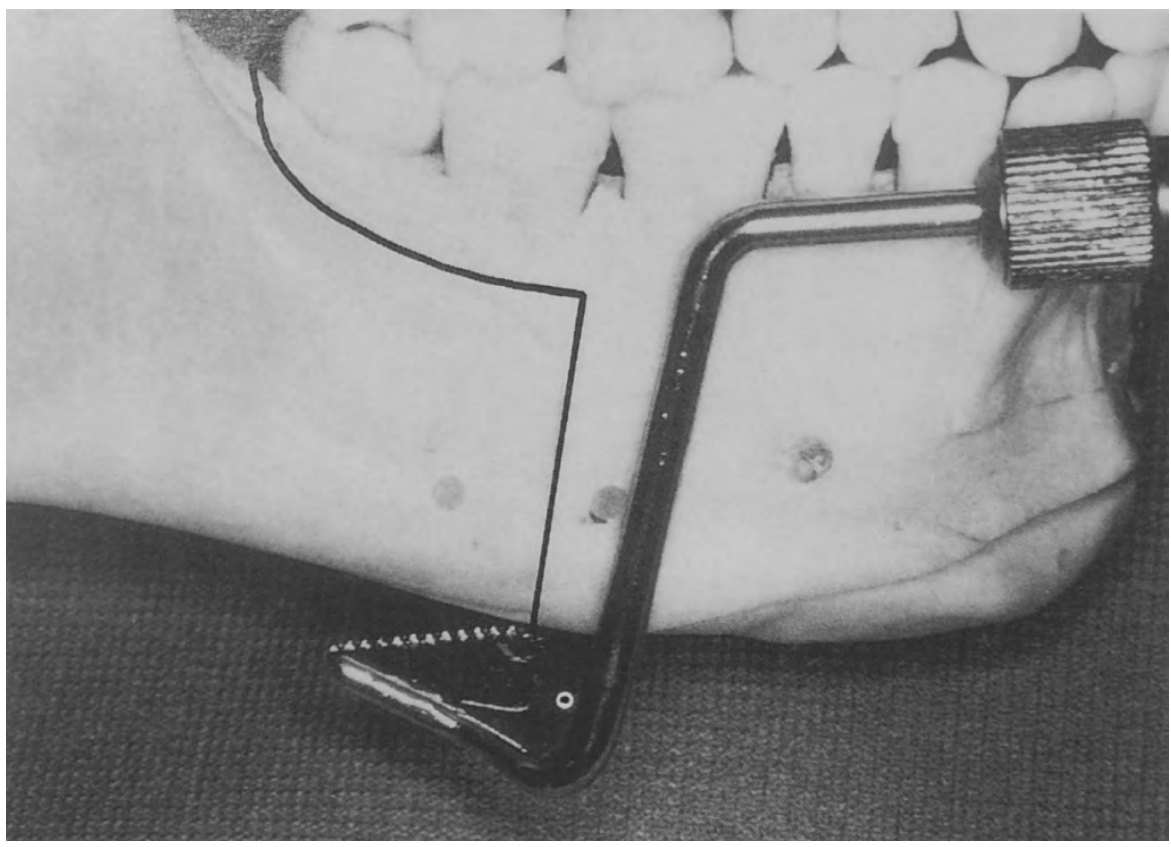

Figure 16 Inferior border osteotomy (Wolford, 1990). ${ }^{21}$ 


\section{COMPLICATIONS OF THE SAGITTAL SPLIT OSTEOTOMY}

Excessive bleeding, unfavorable fracture (bad split), excessive swelling, infection, injury of the inferior alveolar nerve and postoperative relapse are the most common complications in the sagittal split osteotomy. ${ }^{23}$ The most feared complications are the unfavorable fracture, damage to the inferior alveolar nerve and relapse as they almost always influence patient's long-term well-being.

\section{Relapse}

There are many reasons why the planned position of the mandible may change over time: Progressive condylar resorption, condylar mal-positioning during osteosynthesis of the segments, segment relapse due to insufficient osteosynthesis, relocation of the mandible due to muscular activity and ongoing postoperative mandibular growth.

Schuchardt denied relapse caused by the activity of the pterygomasseteric muscular sling $^{11}$ as did Epker. ${ }^{24}$ Dicker et al postulated that the post-operative change of direction of the pterygomasseteric sling does not cause any condylar resorption. ${ }^{25}$

Condylar resorption is characterized by severe morphological changes with decreased condylar volume, decreased ramus height therefore leading to relapse. ${ }^{26}$ Its prevalence ranges from $3,6 \%{ }^{27}$ to $31 \%^{28}$ in high risk patients. As risk factors have been identified: young age and female gender, autoimmune disorders, low estrogen, high prolactin and corticosteroids, a high mandibular plane angle, unstable occlusion or condylar displacement. ${ }^{29}$

Condylar displacement became more frequent after the introduction of the (semi-) rigid osteosynthesis. ${ }^{19}$ Beforehand wire fixation or even no fixation of the segments allowed the condyle to find its physiological position. A relapse can occur if the condyles are mal-positioned during rigid osteosynthesis either with bicortical screws or with miniplates. ${ }^{30}$ Different concepts have been used to secure the condyle in the correct position: Most common is the repositioning by hand, ${ }^{31,32}$ other options are registration with mechanical devices, ${ }^{33,34}$ registration by ultrasound ${ }^{35}$ or registration by navigation. ${ }^{36}$

\section{Damage to the IAN}

Permanent postoperative damage to the IAN can be seen on average in about $5-10 \%$ of all patients with a range from $3 \%$ to $81 \% .{ }^{37-40}$ Three different types of damage can be defined: neurapraxia, axonotmesis and neurotmesis, the first one being the smallest damage and the last the most severe. Neurapraxia usually occurs after temporary ischemia of the nerve caused e.g. by stress (placement of a retractor channel at the median side of the ramus to protect the IAN) or by compression (chisel pushing against the IAN trying to split the mandible). In neurapraxia the integrity of all structures (neuron and perineurium) is preserved and there will be a restitutio ad integrum within weeks. 
In axontomesis the crush or compression on the nerve is more serious than in neurapraxia, leading to degeneration of the myelin sheaths of the neuronal axones. Axonal repair is still possible by using the intact endo-, peri- and epineurium as a guiding tube for the growth of new fibers. Regeneration can take up to 12 months and it can be incomplete.

If all peri-neural layers are disrupted (e.g. damaged by a Lindemann burr or a chisel) the damage is classified as neurotmesis. The nerve halters to function, which in case of the IAN means anesthesia of the innervated area as of the lip and chin. Without further intervention the rate of regeneration of the IAN is low, causing subsequent dysesthesias or permanent anesthesia.

Two groups ${ }^{41-43}$ have identified the medial osteotomy as that with the highest risk of damaging the IAN. The splitting procedure and the fixation of the segments has less but still some impact on the integrity of the IAN. The first two factors are strongly correlated to the procedure itself demanding a bony preparation before the splitting. It should be as least harmful as possible but making the split as predictable as possible.

\section{Unfavorable Splitting}

The risk of an unfavorable or bad split is estimated around $2 \%,{ }^{44,45}$ and studies about this are numerous. As risk factors identified: higher age, ${ }^{46,47}$ presence of third molars particular in young patients, ${ }^{22,47-49}$ a long and thin ramus or a thin mandibular body ${ }^{50}$ or a low mandibular body. ${ }^{51}$ However, some authors found no correlation between impacted third molars and bad splits. ${ }^{52,53}$

Hardly any information is available about the long-term effects of patients having had a bad split. The only significant deterioration of the postoperative result is a smaller mouth opening in these patients. ${ }^{54}$ No information is available about a correlation between a bad split and damage to the IAN. In surgically correctly positioned and precise osteotomies the mandible should split in the correct lines following the rules of Newtonian mechanics independent from torque forces.

\section{BIOMECHANICAL STUDIES OF THE SAGITTAL SPLIT OSTEOTOMY}

No study could be found on the mechanics of the mandibular split itself. However, the osteosynthesis of the split segments has been subject to many studies. ${ }^{55-59}$ Recently there was an article about a finite element based sagittal split simulator ${ }^{60}$ outlining its theoretical background. The finite element method (FEM) divides a system into multiple smaller pieces called finite elements. Now the interaction between these small parts can be described by a variation of different methods by equation. One FEM model of the mandible has been established specifying the deformation of the surface under stress. ${ }^{61}$ The authors missed to identify the different mandibular components for good 
reasons. Finite elements useful to describe the mandibular sagittal splitting could be the elasticity of cancellous bone, cortical bone, neural tissue, dentin and the interaction between these materials. Up until today there is no standard value for cancellous bone in FEM alone. It ranges from 0,4GPa till 15GPa for Young's tissue modulus. ${ }^{62}$

\section{AIM OF THIS STUDY}

This study aims to examine the mandibular sagittal splitting osteotomy by

- Developing a test rack to split animal and human mandibles as in-vivo.

- Modifying the traditional Obwegeser-Dal Pont technique by adding an inferior border osteotomy and proving its reliability in pig mandibles by in-vivo recording of the torque and the fracture pattern.

- Proving the reliability of the modified Obwegeser-Dal Pont technique including the inferior border osteotomy in human mandibles by in-vivo recording of the torque and the fracture pattern.

- Comparison of sagittal split osteotomies preformed by saw or by burr in pig mandibles by in-vivo recording of the torque and the fracture pattern.

- Proving the reliability of the results in sagittal split osteotomies in humans by recording the necessary torque to split the mandible and documentation of the fracture patterns. 


\section{REFERENCES}

1. Hullihen SP. Case of elongation of the underjaw and distorsion of the face and neck, caused by a burn, successfully treated. Am J Dent Sci. 1849;9:157-161.

2. Blair VP. Operations on the jaw-bone and face. Surg Gynecol Obstet. 1907;4:67-78.

3. Blair VP. Surgery and diseases of the mouth and jaws. 2nd ed. St. Louis: C.V. Mosby Company; 1913:241.

4. Eiselsberg von A. Über Plastik bei Ectropium des Unterkiefers. Wien Klin Wochenschr. 1906;19:1505.

5. Perthes GC. Die Verletzungen und Krankheiten der Kiefer. (Bruns von P, ed.). Stuttgart: Enke Verlag; 1907.

6. Perthes GC. Operative Korrektur der Progenie. Zentralb/ Chir. 1922;49:1540-1541.

7. Perthes GC, Borchers E. Verletzungen und Krankheiten der Kiefer. in: Neue Deutsche Chirurgie 53. Band. (Küttner H, ed.). Stuttgart: Ferdinand Enke Verlag; 1932.

8. Kostecka FA. Die chirurgische Therapie der Progenie. Zahnaertzl Rundsch. 1931;40:669-688.

9. Kostecka FA. A contribution to the surgical treatment of open-bite. International Journal of Orthodontia and Dentistry for Children. 1934;20(11):1082-1092.

10. Kazanjian $\mathrm{VH}$. The treatment of mandibular prognathism with special reference to edentulous patients. Oral Surg Oral Med Oral Pathol. 1951;4(6):680-688.

11. Schuchardt K. Die Chirurgie als Helferin der Kieferorthopädie. Fortschritte der Kieferorthopädie. 1954;15(1):1-25.

12. Obwegeser HL. Orthognathic surgery and a tale of how three procedures came to be: a letter to the next generations of surgeons. Clin Plast Surg. 2007;34(3):331-355.

13. Trauner R, Obwegeser HL. Zur Operationstechnik bei der Progenie und anderen Unterkieferanomalien. Dtsch Zahn Mund Kieferheilkd. 1955;23:11-25.

14. Trauner R, Obwegeser HL. The surgical correction of mandibular prognathism and retrognathia with consideration of genioplasty. I. Surgical procedures to correct mandibular prognathism and reshaping of the chin. Oral Surg Oral Med Oral Pathol. 1957;10(7):677-689.

15. Obwegeser HL. The indications for surgical correction of mandibular deformity by the sagittal Splitting Technique. Br J Oral Surg. April 1964:157-171.

16. Dal Pont G. Retromolar osteotomy for the correction of prognathism. J Oral Surg Anesth Hosp Dent Serv. 1961;19:42-47.

17. Hunsuck EE. A modified intraoral sagittal splitting technic for correction of mandibular prognathism. J Oral Surg. 1968;26(4):250-253.

18. Blair VP. Instances of operative correction of mal-relation of the jaws. International Journal of Orthodontia. 1915;1(8):395-421.

19. Spiess/ B. Rigid internal fixation after sagittal split osteotomy of the ascending ramus. In: Spiess| B, ed. New concepts in maxillofacial bone surgery. Berlin, Heidelberg: Springer; 1976:115-122.

20. Blair VP. Surgery and diseases of the mouth and jaws. 1st ed. St. Louis: C.Vm. Mosby Company; 1912.

21. Wolford LM, Davis WM. The mandibular inferior border split: a modification in the sagittal split osteotomy. J Oral Maxillofac Surg. 1990;48(1):92-94.

22. Mehra P, Castro V, Freitas RZ, Wolford LM. Complications of the mandibular sagittal split ramus osteotomy associated with the presence or absence of third molars. J Oral Maxillofac Surg. 2001;59(8):854858.

23. Santos T de S, Albuquerque KM, Sousa Maciel Santos ME, Laureano Filho JR. Survey on complications of orthognathic surgery among oral and maxillofacial surgeons. J Craniofac Surg. 2012;23(5):E423-E430.

24. Epker BN. Modifications in the sagittal osteotomy of the mandible. J Oral Surg. 1977;35(2):157-159.

25. Dicker GJ, Castelijns JA, Tuinzing DB, Stoelinga PJW. Do the changes in muscle mass, muscle direction, and rotations of the condyles that occur after sagittal split advancement osteotomies play a role in the aetiology of progressive condylar resorption? Int J Oral Maxillofac Surg. 2015;44(5):627-631.

26. Hoppenreijs T, Stoelinga P, Grace KL, Robben C. Long-term evaluation of patients with progressive condylar resorption following orthognathic surgery. Int J Oral Maxillofac Surg. 1999;28(6):411-418. 
27. Borstlap WA, Stoelinga PJW, Hoppenreijs TJM, van't Hof MA. Stabilisation of sagittal split advancement osteotomies with miniplates: a prospective, multicentre study with two-year follow-up. Part III--condylar remodelling and resorption. Int J Oral Maxillofac Surg. 2004;33(7):649-655.

28. De Clercq CA, Neyt LF, Mommaerts MY, Abeloos JV, De Mot BM. Condylar resorption in orthognathic surgery: a retrospective study. Int J Adult Orthodon Orthognath Surg. 1994;9(3):233-240.

29. Arnett GW, Gunson MJ. Risk Factors in the initiation of condylar resorption. Semin Orthod. 2013;19(2):81-88.

30. Luhr HG. The significance of condylar position using rigid fixation in orthognathic surgery. Clin Plast Surg. 1989;16(1):147-156.

31. Gerressen M, Stockbrink G, Smeets R, Ghassemi A. Skeletal stability following bilateral sagittal split osteotomy (BSSO) with and without condylar positioning device. J Oral Maxillofac Surg. 2007;65(7):12971302.

32. Sander AK, Martini M, Konermann A-C, Meyer U, Wenghoefer M. Freehand condyle-positioning during orthognathic surgery. J Craniofac Surg. 2015;26(5):1471-1476.

33. Schwestka-Polly R, Engelke D, Kubein-Meesenburg D. Application of the condylar positioning appliance in mandibular sagittal split osteotomies with rigid skeletal fixation. Int J Adult Orthodon Orthognath Surg. $1992 ; 7(1): 15-21$

34. Baek R-M, Lee SW. A new condyle repositionable plate for sagittal split ramus osteotomy. J Craniofac Surg. 2010;21(2):489-490.

35. Landes CA. Proximal segment positioning in bilateral sagittal split osteotomy: intraoperative dynamic positioning and monitoring by sonography. J Oral Maxillofac Surg. 2004;62(1):22-28.

36. Marmulla R, Mühling J. Computer-assisted condyle positioning in orthognathic surgery. J Oral Maxillofac Surg. 2007;65(10):1963-1968.

37. Blomqvist JE, Alberius $P$, Isaksson S. Sensibility following sagittal split osteotomy in the mandible: a prospective clinical study. Plast Reconstr Surg. 1998;102(2):325-333.

38. August M, Marchena J, Donady J, Kaban L. Neurosensory deficit and functional impairment after sagittal ramus osteotomy: a long-term follow-up study. J Oral Maxillofac Surg. 1998;56(11):1231-1235.

39. Agbaje JO, Salem AS, Lambrichts I, Jacobs R, Politis C. Systematic review of the incidence of inferior alveolar nerve injury in bilateral sagittal split osteotomy and the assessment of neurosensory disturbances. Int J Oral Maxillofac Surg. 2015;44(4):447-451.

40. Colella G, Cannavale R, Vicidomini A, Lanza A. Neurosensory disturbance of the inferior alveolar nerve after bilateral sagittal split osteotomy: a systematic review. J Oral Maxillofac Surg. 2007;65(9):17071715.

41. Jones DL, Wolford LM. Intraoperative recording of trigeminal evoked potentials during orthognathic surgery. Int J Adult Orthodon Orthognath Surg. 1990;5(3):167-174.

42. Teerijoki-Oksa T, Jääskeläinen SK, Forssell K, et al. Risk factors of nerve injury during mandibular sagittal split osteotomy. Int J Oral Maxillofac Surg. 2002;31(1):33-39.

43. Jääskeläinen SK, Teerijoki-Oksa T, Forssell K, Vähätalo K, Peltola JK, Forssell H. Intraoperative monitoring of the inferior alveolar nerve during mandibular sagittal-split osteotomy. Muscle Nerve. 2000;23(3):368375.

44. Chrcanovic BR, Freire-Maia B. Risk factors and prevention of bad splits during sagittal split osteotomy. Oral Maxillofac Surg. 2012;16(1):19-27.

45. Steenen SA, Becking AG. Bad splits in bilateral sagittal split osteotomy: systematic review of fracture patterns. Int J Oral Maxillofac Surg. 2016;45(7):887-897.

46. Kriwalsky MS, Maurer P, Veras RB, Eckert AW, Schubert J. Risk factors for a bad split during sagittal split osteotomy. Br J Oral Maxillofac Surg. 2008;46(3):177-179.

47. Reyneke JP, Tsakiris $P$, Becker $P$. Age as a factor in the complication rate after removal of unerupted/impacted third molars at the time of mandibular sagittal split osteotomy. J Oral Maxillofac Surg. 2002;60(6):654-659. 


\section{Chapter 1}

48. Verweij JP, Mensink G, Fiocco M, van Merkesteyn RJPR. Presence of mandibular third molars during bilateral sagittal split osteotomy increases the possibility of bad split but not the risk of other postoperative complications. J Craniomaxillofac Surg. 2014;42(7):E359-E363.

49. Deeb El M, Wolford LM, Bevis R. Complications of orthognathic surgery. Clin Plast Surg. 1989;16(4):825840.

50. Aarabi M, Tabrizi R, Hekmat M, Shahidi S, Puzesh A. Relationship between mandibular anatomy and the occurrence of a bad split upon sagittal split osteotomy. J Oral Maxillofac Surg. 2014;72(12):2508-2513.

51. Witherow H, Offord D, Eliahoo J, Stewart A. Postoperative fractures of the lingual plate after bilateral sagittal split osteotomies. Br J Oral Maxillofac Surg. 2006;44(4):296-300.

52. Precious DS, Lung KE, Pynn BR, Goodday RH. Presence of impacted teeth as a determining factor of unfavorable splits in 1256 sagittal-split osteotomies. Oral Surg Oral Med Oral Pathol. 1998;85(4):362365.

53. Doucet J-C, Morrison AD, Davis BR, Gregoire CE, Goodday R, Precious DS. The presence of mandibular third molars during sagittal split osteotomies does not increase the risk of complications. J Oral Maxillofac Surg. 2012;70(8):1935-1943.

54. Veras RB, Veras RB, Kriwalsky MS, et al. Functional and radiographic long-term results after bad split in orthognathic surgery. Int J Oral Maxillofac Surg. 2008;37(7):606-611.

55. Sato FRL, Asprino L, Consani S, Noritomi PY, de Moraes M. A comparative evaluation of the hybrid technique for fixation of the sagittal split ramus osteotomy in mandibular advancement by mechanical, photoelastic, and finite element analysis. Oral Surg Oral Med Oral Pathol Oral Radiol. 2012;114(5 Suppl):S60S68.

56. Maurer P, Knoll WD, Schubert J. Comparative evaluation of two osteosynthesis methods on stability following sagittal split ramus osteotomy. J Craniomaxillofac Surg. 2003;31(5):284-289.

57. Maurer P, Holweg S, Schubert J. Finite-element-analysis of different screw-diameters in the sagittal split osteotomy of the mandible. J Cranio maxillofac Surg. 1999;27(6):365-372.

58. Bohluli B, Motamedi MHK, Bohluli P, Sarkarat F, Moharamnejad N, Tabrizi MHS. Biomechanical stress distribution on fixation screws used in bilateral sagittal split ramus osteotomy: assessment of 9 methods via finite element method. J Oral Maxillofac Surg. 2010;68(11):2765-2769.

59. Sindel A, Demiralp S, Colok G. Evaluation of different screw fixation techniques and screw diameters in sagittal split ramus osteotomy: finite element analysis method. J Oral Rehabil. 2014;41(9):683-691.

60. Sofronia RE, Knott T, Davidescu A, Savii GG, Kuhlen T, Gerressen M. Failure mode and effects analysis in designing a virtual reality-based training simulator for bilateral sagittal split osteotomy. Int J Med Robot. 2013;9(1):e1-e9.

61. Meyer U, Vollmer D, Homann C, et al. [Experimental and finite-element models for the assessment of mandibular deformation under mechanical loading]. Mund Kiefer GesichtsChir. 2000;4(1):14-20.

62. van Rietbergen $B$, Weinans $H$, Huiskes $R$, Odgaard A. A new method to determine trabecular bone elastic properties and loading using micromechanical finite-element models. J Biomech. 1995;28(1):69-81.

63. Dal Pont G. L'osteotomia retromolare per la correzione della progenia. Minerva Chir. 1959;14:11381141. 


\section{Chapter}

\section{The modifications of the sagittal ramus split osteotomy: a literature review}

R. Böckmann, J. Meyns, E. Dik, P.A.W.H. Kessler

Published in Plastic \& Reconstructive Surgery Global Open. 2014;2(12):e271

Awarded as "Best Regional Paper 2015 - Europe" by PRS Global Open 


\section{ABSTRACT}

Background: In 1953, the sagittal ramus split osteotomy was introduced by Obwegeser. For many years, and in some countries still, this technique has defined the term oral and maxillofacial surgery.

Methods: The basic design of the sagittal ramus split surgical procedure evolved very quickly. The original operation technique by Obwegeser was shortly after improved by Dal Pont's modification. The second major improvement of the basic technique was added by Hunsuck in 1967. Since then, the technical and biological procedure has been well defined. Resolution of the problems many surgeons encountered has, however, taken longer. Some of these problems, such as the unfavorable split or the damage of the inferior alveolar nerve, have not been satisfactorily resolved.

Results: Further modifications, with or without the application of new instruments, have been introduced by Epker and Wolford, whose modification was recently elaborated by Böckmann. The addition of a fourth osteotomy at the inferior mandibular border in an in-vitro experiment led to a significant reduction of the torque forces required for the mandibular split.

Conclusions: The literature was reviewed, and the last modifications of the successful traditional splitting procedure are presented narrowly. It indicates the better the split is preformatted by osteotomies, the less torque force is needed while splitting, giving more controle, a better predictability of the lingual fracture and maybe less neurosensory disturbances of the inferior alveolar nerve. 


\section{INTRODUCTION}

The historical development of orthognathic surgery has followed a rather stepwise, intermittent course. The first mandibular osteotomy is considered to be Hullihen's ${ }^{1}$ procedure in 1849 for the correction of a protruded alveolar mandibular segment. The first osteotomy of the whole mandibular body for the correction of prognathism was performed by Blair ${ }^{2}$ in 1897 . He was also the first author to present a classification of jaw deformities. The operations performed, described, and published by Blair and Angle $^{3}$ marked the beginning of the development of oral surgery. In 1953, the sagittal split osteotomy evolved into a procedure that could be accomplished intraorally, without transfacial approaches and without leaving visible scars. The bilateral sagittal split osteotomy (BSSO) can be considered a milestone in surgery in general. ${ }^{4,5}$ The following review of the literature is an attempt to isolate the modifications, which marked significant advances of this technique.

\section{Review of the literature}

In 1907, Blair ${ }^{2}$ published the horizontal subcondylar osteotomy of the mandible to correct class II dysgnathias by advancement of the mandibular body. This technique required prolonged intermaxillary fixation, which was already regarded as an inconvenience due to a lack of bone contact between the osteotomized segments. A modification of this technique was recently published again by Hågensli et al. ${ }^{6}$ Using an overlapping segmentation technique and osteosynthesis plates, they claimed to achieve good bone healing. Schuchardt ${ }^{7}$ modified the horizontal flat osteotomy by introducing a technique in which a cortical osteotomy was performed in an oblique way starting from just above the lingula and reaching the buccal cortex $1 \mathrm{~cm}$ more caudally without touching the inferior alveolar nerve (IAN). The Schuchardt operation could be performed intraorally and led to a more sufficient medullary bone attachment. However, without fixation of the proximal and distal segments, this procedure only led to a minor reduction of complications. Trauner and Obwegeser ${ }^{4,5}$ further developed Schuchardt's technique by increasing the gap between the horizontal cuts to $25 \mathrm{~mm}$, requiring the surgeon to address the IAN. Their innovation resulted from connecting 2 horizontal cortical cuts along the lateral oblique ridge and leaving the posterior border of the ramus untouched. Eventually, the fracture of the ramus was achieved by chiseling along the lateral cortex. This procedure was called the sagittal splitting procedure, and it kept the IAN intact. The wider distance between the lingual and buccal cuts increased the overlapping bony amount of the segments, which rendered better stability and better results at a lower risk of pseudarthrosis (Fig. 1). Obwegeser revolutionized oral and maxillofacial surgery by introducing the BSSO as a standardized and safe procedure, which is performed worldwide to date in the originally described manner. 


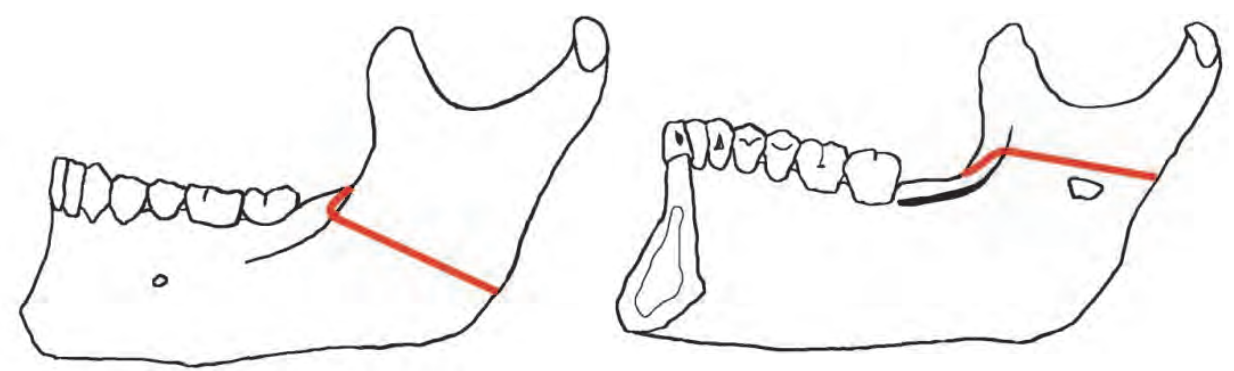

Figure 1. The sagittal split as described by Obwegeser. the buccal and lingual osteotomy lines are indicated.

In times of osteosynthesis by wiring, Dal Pont's $s^{8}$ modification advances and rotates the lower horizontal cut even further to the buccal cortex of the mandibular body as a vertical cut between the first and second molars. The angle created between the lingual and buccal cortical cuts was approximately 90 degrees, leading to an extension of the connecting cut along the oblique line on the lateral mandibular aspect through the mylohyoid groove on the lingual side (Fig. 2). In the same article, Dal Pont reported a less quoted alternative technique that he called the "oblique retromolar osteotomy". The lingual horizontal corticotomy ended just behind the lingula. However, it was Hunsuck $^{9}$ who thought that it was not necessary to make an actual cut through the lingula as Dal Pont had done in his technique.

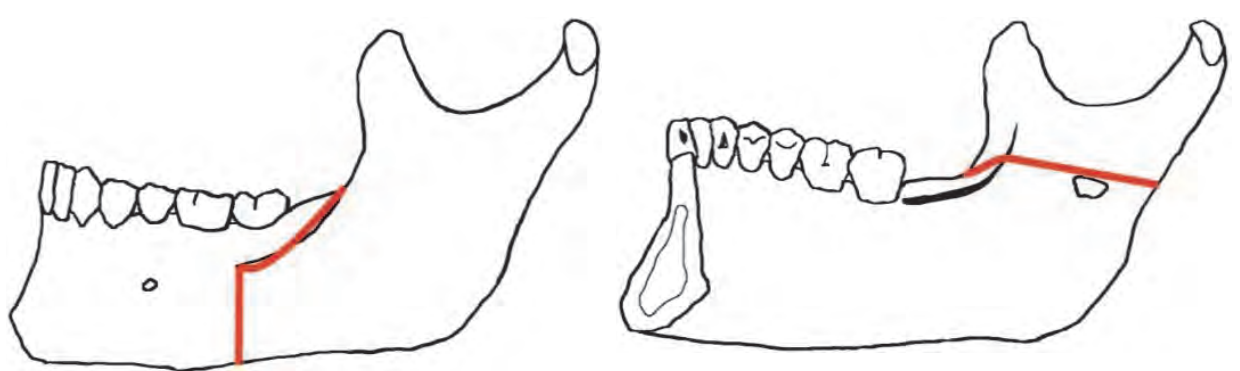

Figure 2. The first modification of the sagittal split by Dal Pont. The buccal and lingual osteotomy lines are indicated.

Hunsuck was convinced that the lingual split of the Dal Pont osteotomy would occur naturally given that chisels were used to split the mandible. The buccal vertical cut by Hunsuck was located at the "union of the ascending ramus and the body of the mandible in the tooth bearing region". In Hunsuck's illustrations, this area was just distal of the second molar running down to the mandibular notch anterior of the insertion point of the masseteric muscle (Fig. 3). As with Obwegeser, a single wire was placed at the anterior aspect of the ascending ramus at the height of the occlusal plane. All 3 techniques by Obwegeser, Dal Pont, and Hunsuck required tunneling of the lingual ptery- 
gomandibular space with only minimal muscular or periosteal stripping. A massetericomandibular tunnel was only necessary in the original technique described by Obwegeser. $^{4}$
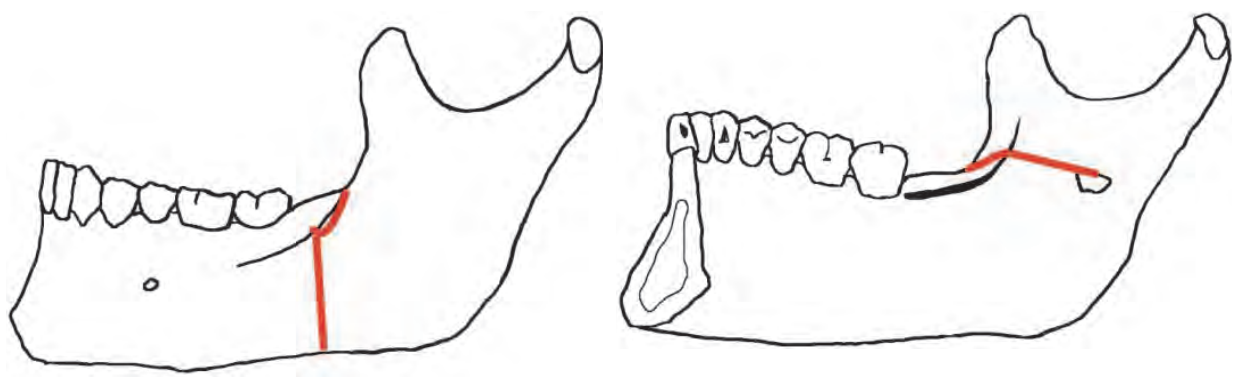

Figure 3. The modification of the lingual cut according to Hunsuck and epker. Notice the short horizontal cut on the lingual side.

In 1977, a very important article on the biological basis of the BSSO was published by Bell and Schendel. ${ }^{10}$ This article tried to explain some of the problems biologically, and it laid the path for future modifications. It was a reminder that the clinical success of a surgical technique must be based on or proven or at least guided by laboratory research. The Bell and Schendel publication delineated the basic principles leading to the article published by Epker in 1977. ${ }^{11}$ Based on the growing knowledge on muscular and temporomandibular joint function, a more biological modification evolved. Wide reflection of the masseteric muscle to prevent relapse was denied by Epker in favor of a 2wire stabilization of both segments proximally low and distally high. Therefore, the condylar sag leading to relapse could be prevented. Furthermore, Epker refined the original Dal Pont technique by explaining the buccal corticotomy in detail, emphasizing the need for a complete osteotomy of the inferior mandibular cortex to avoid bad splits.

Following the foundation of the "Arbeitsgemeinschaft für Osteosynthesefragen" (AO) at Biel, Switzerland, in 1958, the next revolution started affecting the BSSO technique. In 1976, Spiessl ${ }^{12}$ published their book New Concepts in Maxillofacial Bone Surgery in which they introduced rigid internal fixation in the form of interfragmentary bone screws. Their research showed that the screws added to the stability of the fragments and decreased healing time because of fragment compression osteosynthesis. In addition, Spiessl also favored the use of thin bone saws for precise osteotomies over thicker burrs, thereby saving as much bone as possible to reduce the gap between the split segments. Only small gaps were allowed for stable compression osteosynthesis. Spiessl also introduced a new osteotomy technique by removing the lingual aspect of the cortical bone plate covering the oblique line in the retromolar region. By its removal, a good overview was created to discern the cancellous and cortical bone structures of the retromolar lingual mandible. He also performed the first preliminary anatomical 
studies on the variation of the location of the mandibular nerve in relation to the lateral mandibular cortex.

In the 1980s, Bell et al $^{13,14}$ and Steinhäuser and Rudzki-Janson ${ }^{15}$ published 2-volume book sets about the basic principles of the osteotomy techniques in orthognathic surgery. These books continue to be used as basic literature for those beginning to perform orthognathic surgery. Whereas Bell failed to introduce rigid screw fixation, Steinhäuser did follow the principles of the $A O$ and reported on it to his American colleagues. Bell et al $^{16}$ then switched from the wire osteosynthesis to rigid fixation in 1985 by adding a third volume to his existing 2-volume book sets.

Nevertheless, the problem of injuring the inferior alveolar nerve remained. In 1986, using the new computed tomography scan technology at that time, Rajchel et al ${ }^{17}$ suggested rethinking the position of the anterior buccal osteotomy. He was the first author to report specifically on the mediolateral position of the mandibular nerve, and he concluded that the buccal vertical corticotomy has to be located in the region of the first molar for the safety of the IAN. He described this region as a "bony prominence, an extension of the lateral oblique line". Anatomically, this description is correct, as the area just distal to the second molar is the region where the neurovascular bundle is most often located in direct contact with the buccal cortex. Occasionally, the neurovascular bundle and canal seem to be within the buccal cortical plate. The risk of injuring the inferior alveolar nerve is high.

Wolford et $\mathrm{al}^{18}$ and Obwegeser and Hadjianghelou ${ }^{19}$ reacted to this article. Wolford agreed on moving the vertical cut further anterior in the region of the first and second molars to avoid direct trauma to the inferior alveolar nerve. Furthermore, he was in favor of using position screws over compression screws to prevent possible traumatic nerve compression and condylar displacement. He was the first author to recommend early mobilization of the mandible resulting from the rigid osteosynthetic fixation. This early functional approach was intended to mobilize the temporomandibular joints as early as possible. Obwegeser responded to the discussion started by Rajchel with an article titled "Two ways to treat bird-face deformity". The interesting aspect of that article was his use of a vertical cut that was even further forward than in any previously published article. The vertical cut was located between the second premolar and first molar. Based on the studies performed by Rajchel, this modification is reasonable because depending on the location of the mental foramen, the inferior alveolar nerve is usually still located medially at that point.

Radiological studies on the lingual split design revealed that in the conventional technique, the split usually occurred in the lingual cortical plate. A high lingual split made it impossible to place the third screw inferiorly to the alveolar canal, as there was no bone for fixation on the lingual side. Therefore, Wolford and Davis ${ }^{20}$ introduced the concept of the inferior border split in 1990. A specially designed saw was used to cut the inferior border, thus leading to a low lingual split. Another advantage of the Wolford modification was that the inferior alveolar nerve was less frequently found in the prox- 
imal segment, where the nerve is more prone to trauma due to tension, bad visualization, and separation of the nerve from the canal.

Rigid internal fixation has been the state-of-the art fixation in orthognathic surgery since the 1980s. Its advantages are obvious: no rigid intermaxillary fixation is necessary, which contributes to patient comfort, and fragments tend not to displace after they have been rigidly, internally fixed, compared with fixation using wire osteosynthesis. The latter advantage is extremely important because pull of the masticatory and anterior neck muscles tends to dislocate the fragments, particularly in the mandible when advancing the mandible after a BSSO procedure.

In essence, a sagittal split osteotomy can be fixed in 3 ways: using lag screws, positional screws, and miniplates with monocortical screws. Lag screws were introduced by Spiessl ${ }^{21}$ and were later popularized by Paulus and Steinhäuser. ${ }^{22}$ Three screws are usually used, engaging the buccal cortex of the proximal fragment and the lingual cortex of the distal fragments. Screw threads only engage the lingual cortex. Positional screws are most likely used more often and follow the same principle as lag screws in that usually 3 screws are used, engaging both cortices. The difference is that the fragments are not pulled together as tightly as in the case of lag screws because screw threads engage both cortices. The principle of the use of miniplates was introduced by Michelet et al. ${ }^{23}$ Michelet and Champy started to use small osteosynthesis plates with monocortical screws in trauma and orthognathic patients, thus introducing the term "functional stability" versus rigid compression osteosynthesis as defined by the AO. The advantages of miniplate fixation are well documented in the literature. ${ }^{24-26}$

Recently, distraction osteogenesis (DO) for mandibular retrognathia has become of increasing interest. Although randomized clinical trials are lacking, some support was found for DO having advantages over the classical BSSO in the surgical treatment of low and normal mandibular plane angle patients needing greater advancement of more than $7 \mathrm{~mm}$. The technique of bone splitting tends to prefer the Dal Pont osteotomy as this approach enables better fixation of the distraction device. Long-term results as presented by de Lange and coworkers showed no advantage of DO against the classical splitting procedures. There might be an indication for DO in extreme cases of mandibular micrognathia as, for example, in syndromal diseases. ${ }^{27-29}$

However, the introduction of DO in combination with ultrasonic bone-cutting surgery (piezosurgery) has changed the way of cutting the mandibular bone. ${ }^{30}$ The piezosurgery medical devices allow the efficient cutting of mineralized, hard tissues with minimal trauma to soft tissues. The advantages include minimal risks to critical soft structures, such as the vessels and nerve in the mandibular canal. The oblique osteotomy line can be placed in the retromolar region and runs from the anterobuccal side in a posteromedian direction to the lingual side of the mandibular body. Due to the osteogenic effect of DO, a wide overlap of bone segments as in the classical BSSO is not required. Thus, the introduction of piezosurgery in combination with DO seems to put the old osteotomy techniques into perspective. 
Despite a large number of variations of the original Obwegeser-Dal Pont splitting technique, the risk of unexpected fractures is a major disadvantage of the BSSO, ${ }^{31}$ known as "bad splits". Previous reports have cited an incidence of bad splits of up to $5 \%$ despite improved preoperative diagnostics. In addition, the temporary or lasting damage of the IAN remains relevant. According to the literature, postoperative damage varies from $13 \%$ to $40 \%{ }^{32,33}$

Teerijoki-Oksa et al $^{34}$ identified the splitting maneuver itself as one of the 2 main risks of damaging the IAN. It is common sense that a sufficiently deep cut to the inferior mandibular rim is crucial for a good splitting. This problem has previously been addressed by Wolford and Davis ${ }^{20}$ with the development of a special cutting saw. Due to its design and consequent risk of damaging the facial artery, this instrument never became popular.

In their studies, Böckmann et $\mathrm{al}^{35}$ continued to investigate the advantages of adding a fourth caudal osteotomy parallel with inferior mandibular rim (Figs. 4-6). Wolford's hypothesis was that weakening the inferior mandibular border would result in the proximal cortical border of the ramus as the only cortex to split spontaneously. In doing so, one may achieve a more predictable splitting (Fig. 7). The acquired data confirmed the theory. ${ }^{35}$ In the animal cadaver study, it could be demonstrated that with support of a fourth osteotomy, a reasonable splitting result was always possible to achieve, staying off the IAN during the splitting procedure at the same time.

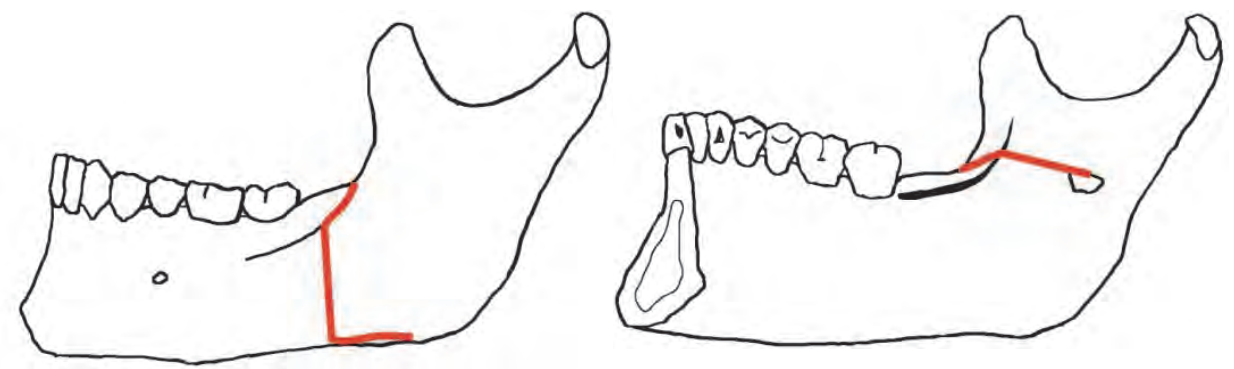

Figure 4. Introduction of the caudal (fourth) osteotomy. As the osteotomy reaches the mandibular angle, it allows the surgeon to split the mandible as if opening a book. 


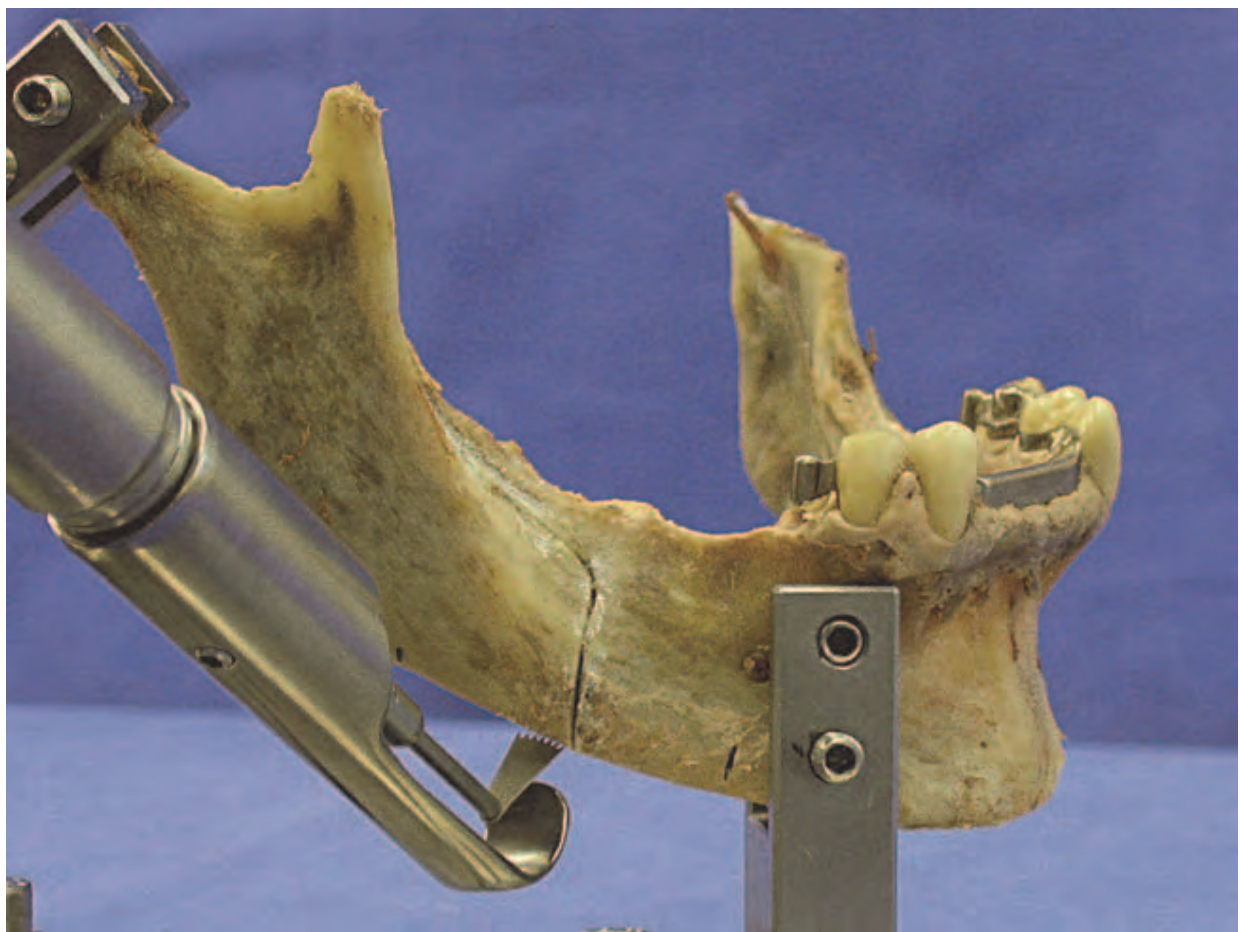

Figure 5. Buccal view of the fourth osteotomy line in a human mandible mounted on a test rack.

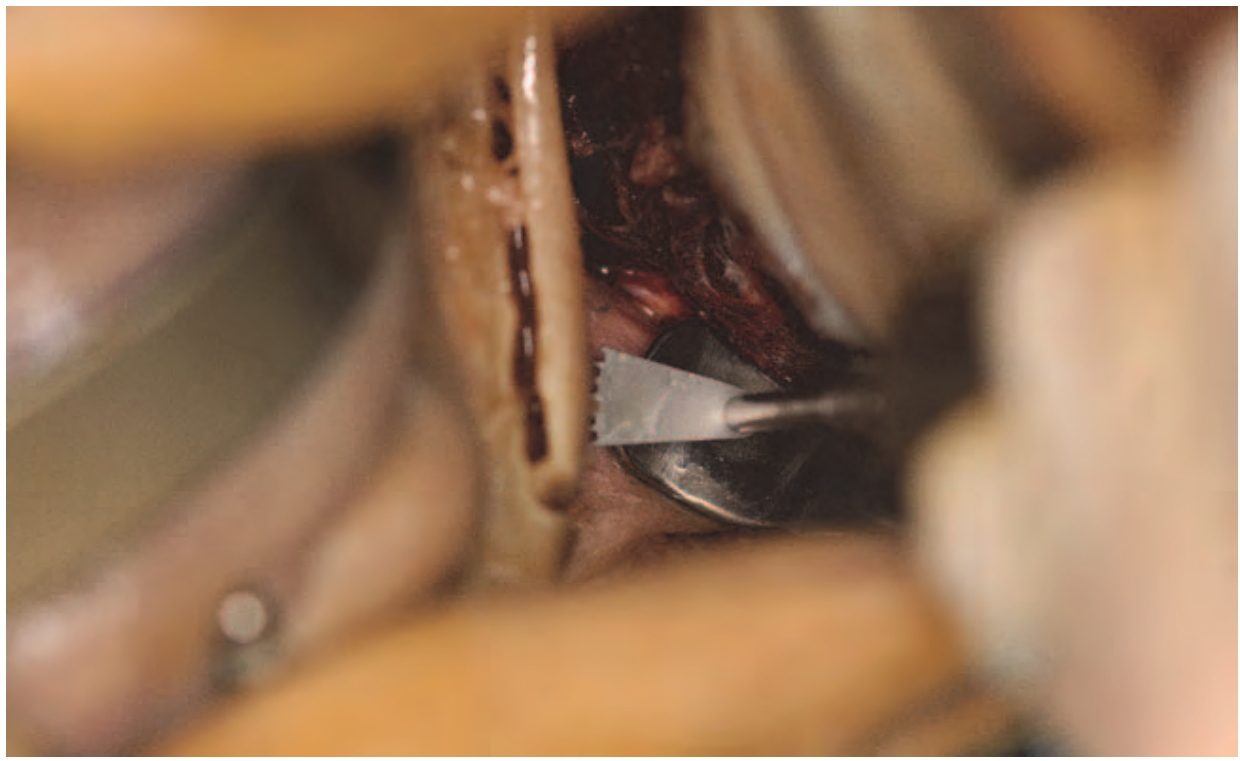

Figure 6. Oscillating saw in situ for preparation of the fourth osteotomy line at the inferior mandibular rim. An L-shield protects the surrounding soft tissue and guides the saw. 


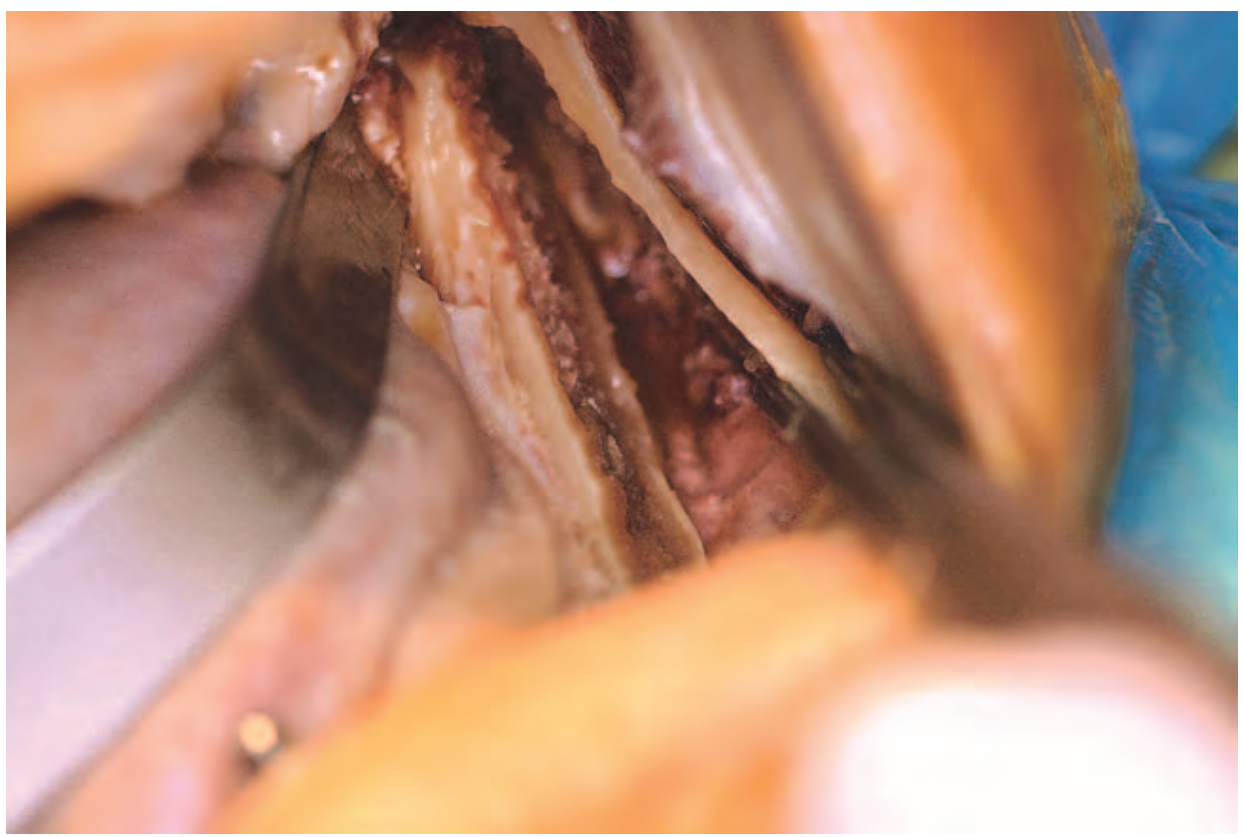

Figure 7. Splitting pattern in the same mandible supported by a fourth osteotomy.

\section{DISCUSSION}

The literature review indicates that all of the major aspects of the design of the sagittal split technique were in place with Hunsuck's modification of the basic Obwegeser-Dal Pont technique. The fact that there are continued attempts to improve this technique is a testament to the understanding of the value of this 60 -year-old procedure. ${ }^{35}$ The subsequent modifications have generally focused on the attempts to manage or minimize the intra- or postsurgical problems that have since emerged. The major problems include neurological injuries, unfavorable splits, relapse, fragment, and condylar resorption. There are, however, no easy solutions to the problems that continue to occur, and most of these problems will likely always be associated with the BSSO technique.

Modifying the Obwegeser-Dal Pont technique by adding an osteotomy of the inferior border of the mandible might be a step in this direction. The research published by Wolford et al has been a valuable guide for locating the additional osteotomy line. The Dal Pont modification, backed up with the anatomical studies by Rajchel et al, indicates that the most favorable area for the buccal cut is in the region between the first and second molars. The distance between the inner aspect of the buccal cortical plate and the mandibular canal is consistently bigger in that location than elsewhere, though the exact spot varies from patient to patient. When considering possible fracture lines on the lingual mandibular aspect connecting the posterior end of the horizontal osteotomy 
and the inferior end of the vertical osteotomy, it is obvious that a fourth osteotomy line at the inferior rim of the mandibular corpus will shorten the necessary connecting fracture line. In an ideal setting, the inferior cut will naturally be located in the middle of the inferior border. The length of the fourth osteotomy line is essential, in facilitating a safe split, as this line has to connect the buccal cut with the region where the ascending ramus and the body of the mandible meet.

\section{CONCLUSION}

Most of the modifications of the original splitting procedure in the first 20 years after its introduction were meant to minimize the risk of pseudarthrosis, nonunion, and 2 split segments. With the introduction of osteosynthesis by screws or by miniplates, this problem has been solved, and the focus has shifted to other complications such as the unfavorable split or the damage of the IAN. These 2 problems are partially linked to one another. One imaginable approach to target both problems is the use of a caudal, a fourth, osteotomy of the mandibular body. Currently, there is no suitable instrument at hand that is easy to handle and that allows the surgeon to cut the inferior border in a predictable and safe way to reduce complications in orthognathic splitting procedures. 


\section{REFERENCES}

1. Hullihen SP. Case of elongation of the underjaw and distorsion of the face and neck, caused by a burn, successfully treated. Am J Dent Sci. 1849;9:157-161.

2. Blair VP. Operations on the jaw-bone and face. Surg Gynecol Obstet. 1907;4:67-78.

3. Biederman W. The strange story of the Angle operation. Ann Dent. 1956;15:1-9.

4. Trauner R, Obwegeser HL. Zur Operationstechnik bei der Progenie und anderen Unterkieferanomalien. Dtsch Zahn Mund Kieferheilkd. 1955;23:11-25.

5. Trauner R, Obwegeser HL. The surgical correction of mandibular prognathism and retrognathia with consideration of genioplasty. I. Surgical procedures to correct mandibular prognathism and reshaping of the chin. Oral Surg Oral Med Oral Pathol. 1957;10(7):677-689.

6. Hågensli N, Stenvik A, Espeland L. Extraoral vertical subcondylar osteotomy with rigid fixation for correction of mandibular prognathism. Comparison with bilateral sagittal split osteotomy and surgical technique. J Craniomaxillofac Surg. 2013;41(3):212-218.

7. Schuchardt K. Ein Beitrag zur chirurgischen Kieferorthopädie unter Berücksichtigung ihrer für die Behandlung angeborener und erworbener Kieferdeformitäten bei Soldaten. Dtsch Z Mund Kiefer Gesichtschir. 1942;9:73-89.

8. Dal Pont G. Retromolar osteotomy for the correction of prognathism. J Oral Surg Anesth Hosp Dent Serv. 1961;19:42-47.

9. Hunsuck EE. A modified intraoral sagittal splitting technic for correction of mandibular prognathism. J Oral Surg. 1968;26(4):250-253.

10. Bell WH, Schendel SA. Biologic basis for modification of the sagittal ramus split operation. J Oral Surg. 1977;35(5):362-369.

11. Epker BN. Modifications in the sagittal osteotomy of the mandible. J Oral Surg. 1977;35(2):157-159.

12. Spiessl B. Rigid internal fixation after sagittal split osteotomy of the ascending ramus. In: Spiessl B, ed. New concepts in maxillofacial bone surgery. Berlin, Heidelberg: Springer; 1976:115-122.

13. Bell WH, Proffit WR, White RP. Surgical correction of dentofacial deformities, Vol I. Vol 1. Philadelphia: W.B. Saunders Company; 1980.

14. Bell WH, Proffit WR, White RP. Surgical correction of dentofacial Deformities, Vol II. Vol 2. Philadelphia: W.B. Saunders Company; 1980.

15. Steinhäuser EW, Janson I. Kieferorthopädische Chirurgie Vol 2. Vol 2. 1st ed. Berlin: Quintessenz; 1994.

16. Bell WH, Proffit WR, White RP. Surgical correction of dentofacial Deformities: new concepts, Vol III. Vol 3. Philadelphia : W.B. Saunders Company; 1985.

17. Rajchel J, Ellis E, Fonseca RJ. The anatomical location of the mandibular canal: its relationship to the sagittal ramus osteotomy. Int J Adult Orthodon Orthognath Surg. 1986;1(1):37-47.

18. Wolford LM, Bennett MA, Rafferty CG. Modification of the mandibular ramus sagittal split osteotomy. Oral Surg Oral Med Oral Pathol. 1987;64(2):146-155.

19. Obwegeser HL, Hadjianghelou O. Two ways to correct bird-face deformity. Oral Surg Oral Med Oral Pathol. 1987;64(5):507-518.

20. Wolford LM, Davis WM. The mandibular inferior border split: a modification in the sagittal split osteotomy. J Oral Maxillofac Surg. 1990;48(1):92-94.

21. Spiessl B. The sagittal splitting osteotomy for correction of mandibular prognathism. Clin Plast Surg. 1982;9(4):491-507.

22. Paulus GW, Steinhäuser EW. A comparative study of wire osteosynthesis versus bone screws in the treatment of mandibular prognathism. Oral Surg Oral Med Oral Pathol. 1982;54(1):2-6.

23. Michelet FX, Benoit JP, Festal F, Despujols P, Bruchet P, Arvor A. [Fixation without blocking of sagittal osteotomies of the rami by means of endo-buccal screwed plates in the treatment of antero-posterior abnormalities]. Rev Stomatol Chir Maxillofac. 1971;72(4):531-537.

24. Stoelinga PJW, Borstlap WA. The fixation of sagittal split osteotomies with miniplates: the versatility of a technique. J Oral Maxillofac Surg. 2003;61(12):1471-1476. 
25. Borstlap WA, Stoelinga PJW, Hoppenreijs TJM, van't Hof MA. Stabilisation of sagittal split advancement osteotomies with miniplates: a prospective, multicentre study with two-year follow-up. Part I. Clinical parameters. Int J Oral Maxillofac Surg. 2004;33(5):433-441.

26. Borstlap WA, Stoelinga PJW, Hoppenreijs TJM, Hof MAV. Stabilisation of sagittal split advancement osteotomies with miniplates: a prospective, multicentre study with two-year follow-up:Part III. Condylar remodelling and resorption. Int J Oral Maxillofac Surg. 2003;33(7):649-655.

27. Schreuder WH, Jansma J, Bierman MWJ, Vissink A. Distraction osteogenesis versus bilateral sagittal split osteotomy for advancement of the retrognathic mandible: a review of the literature. Int J Oral Maxillofac Surg. 2007;36(2):103-110.

28. Wiltfang J, Hirschfelder U, Neukam FW, Kessler PAWH. Long-term results of distraction osteogenesis of the maxilla and midface. Br J Oral Maxillofac Surg. 2002;40(6):473-479.

29. Baas EM, Pijpe J, de Lange J. Long term stability of mandibular advancement procedures: bilateral sagittal split osteotomy versus distraction osteogenesis. Int J Oral Maxillofac Surg. 2012;41(2):137-141.

30. Rana M, Rana M, Piffkó J, Kater W. Evaluation of surgically assisted rapid maxillary expansion with piezosurgery versus oscillating saw and chisel osteotomy - a randomized prospective trial. Trials. 2013;14:49.

31. Kriwalsky MS, Maurer P, Veras RB, Eckert AW, Schubert J. Risk factors for a bad split during sagittal split osteotomy. Br J Oral Maxillofac Surg. 2008;46(3):177-179.

32. Colella G, Cannavale R, Vicidomini A, Lanza A. Neurosensory disturbance of the inferior alveolar nerve after bilateral sagittal split osteotomy: a systematic review. J Oral Maxillofac Surg. 2007;65(9):17071715.

33. Nesari S, Nesari S, Kahnberg KE, Rasmusson L, Rasmusson L. Neurosensory function of the inferior alveolar nerve after bilateral sagittal ramus osteotomy: a retrospective study of 68 patients. Int J Oral Maxillofac Surg. 2005;34(5):495-498.

34. Teerijoki-Oksa T, Jääskeläinen SK, Forssell K, et al. Risk factors of nerve injury during mandibular sagittal split osteotomy. Int J Oral Maxillofac Surg. 2002;31(1):33-39.

35. Böckmann RA, Schön P, Frotscher M, Eggeler G, Lethaus B, Wolff K-D. Pilot study of modification of the bilateral sagittal split osteotomy (BSSO) in pig mandibles. J Craniomaxillofac Surg. 2011;39(3):169-172. 



\section{Chapter}

\section{Pilot study of modification of the bilateral sagittal split osteotomy (BSSO) in pig mandibles}




\section{ABSTRACT}

Objective: This study investigated a new technique for the bilateral sagittal split osteotomy (BSSO) by adding a new osteotomy line at the inferior border of the mandible in the Obwegeser-Dal Pont operation.

Material and methods: For this purpose a test system was designed and 100 pig mandibles were split to assess the test's reliability, to compare the torque necessary to split the mandible in both techniques and to record the fracture lines. The splitting technique was standardized, avoiding any contact with the inferior alveolar nerve. All outcomes were statistically examined by paired $t$-tests.

Results: By using the new technique, we demonstrated a decrease in the torque force required to split the mandible of $29.7 \%(t(69)=-12.68 ; p<0.05$, paired $t$-test) compared to the Obwegeser-Dal Pont technique. The fracture lines were close to ideal.

Conclusion: The additional osteotomy facilitates the BSSO technique and it reduces the likelihood of bad splits and damage to the inferior alveolar nerve in pig mandibles. 


\section{INTRODUCTION}

An osteotomy of the mandible is one of the commonest surgical procedures used in orthognathic surgery. At the beginning of the last century extraoral approaches were used to achieve this goal ${ }^{1-3}$ frequently resulting in visible scarring, pseudarthrosis, lip numbness and even facial nerve palsy. A milestone was set by Trauner and Obwegeser, ${ }^{4,5}$ who introduced the technique of the bilateral sagittal split osteotomy (BSSO), then conducted via an intraoral approach. This new technique led to a significant reduction in all complications. Furthermore aesthetic results improved, as the proximal mandibular segment remained in its original position. Since its introduction many modifications of the original technique have been described to decrease the risk of bad splits, to avoid bony non-union and to prevent trauma to the alveolar nerve. ${ }^{6-11}$

Besides the introduction of new operative techniques to split the mandible, new instruments were developed to refine existing techniques and to make it more atraumatic. Markiewicz introduced a new retractor to improve the vertical osteotomy in the Obwegeser-Dal Pont operation. ${ }^{12}$ A refined technique for a less traumatic operation by endoscopy was presentated by Mommaerts. ${ }^{13}$

Nevertheless, the risk of unexpected fractures is a major disadvantage of the BSSO ${ }^{14,15}$ known as "bad splits". Previous reports have cited an incidence of bad splits of up to $5 \%$, in spite of improved preoperative diagnostics. ${ }^{16,17}$

In this study we investigated the advantages of an additional osteotomy to the technique by Obwegeser-Dal Pont. In this modified technique the inferior border of the mandible is weakened by an osteotomy, thus creating a new line of minor resistance. In this way we hope to reduce the osteotomy depth and additionally to reduce the torque necessary for the splitting process. This should make the splitting manoeuvre more controlable and lead to fewer complications in repositioning the mandible.

\section{MATERIAL AND METHODS}

To standardize the split procedure, we constructed a test rig out of stainless steel with a rigid fixture on one side and a moveable three-dimensional fixture on the other. Each fixture contains six screws to fix the mandible. A holder with a torque gauge was installed, carrying a chisel that split the bone. The jaw and chisel can be aligned precisely and reproducibly (Fig. 1).

We used 30 adult pig mandibles (sus scrofa domestica, Schlachthof Bochum GmbH, Bochum, Germany) to calibrate the test system. These pigs were about 24 weeks old and weighed about $110 \mathrm{~kg}$. Overall mandibular length was between 18 and $22 \mathrm{~cm}$. For the experimental study the mandibles were cut along the median line and both hemimandibles were separately used for the splitting procedure. The split procedure was 
randomly assigned to the standard Obwegeser-Dal Pont and the modified technique implementing a fourth osteotomy line at the inferior border of the mandibular body.

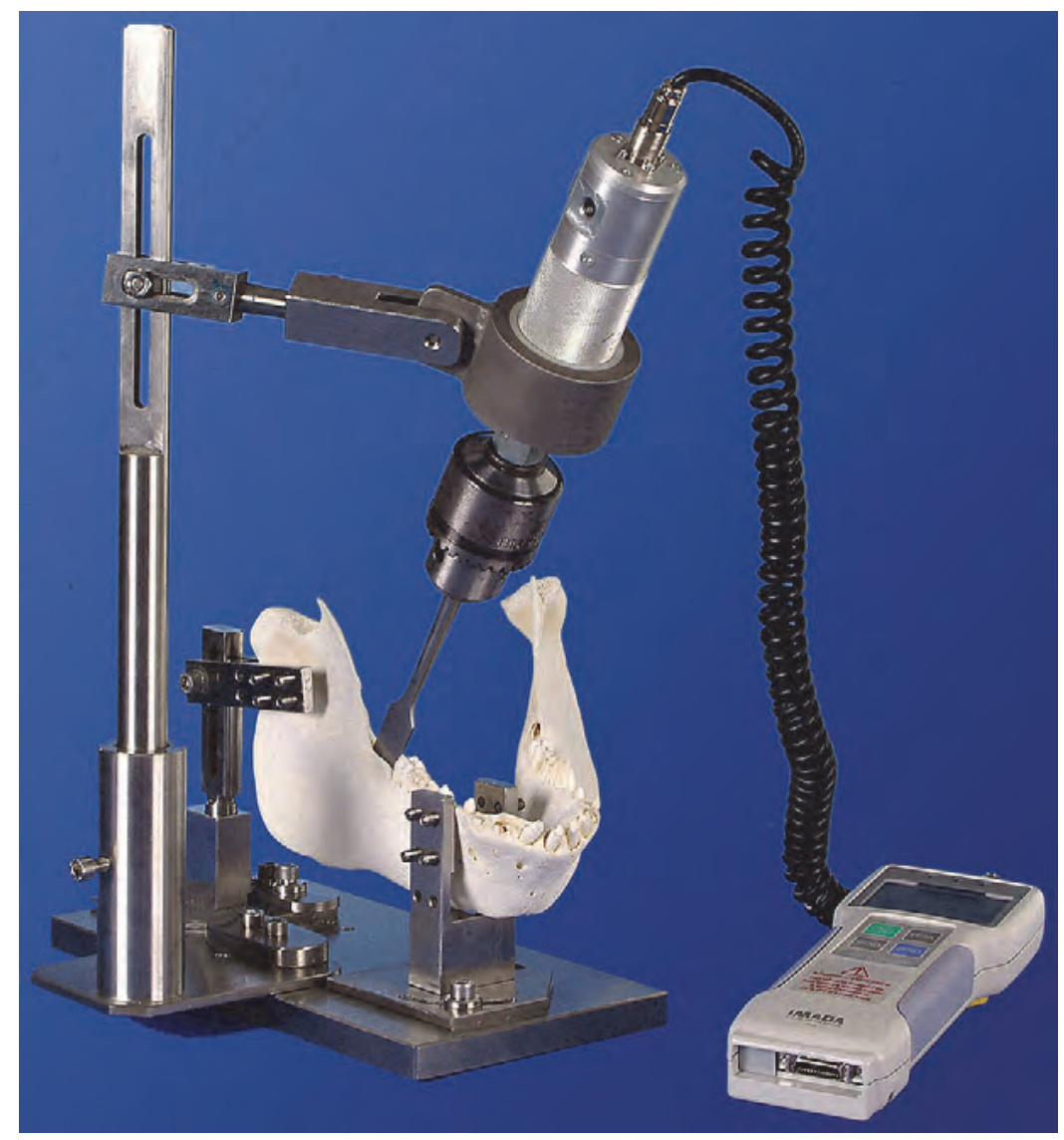

Figure 1. Test rig with a pig mandible and the chisel connected to a torque gauge.

After calibration and validation of the test system and method, an additional 70 pig mandibles were tested to compare the two splitting methods. Again each mandible was cut in two halves. In contrast to the first test series a BSSO according to Obwegeser-Dal Pont was performed on one half and the new technique with an additional inferior border osteotomy on the other half.

To take the individual size and differences in shape of the mandibles into account, each mandible was measured separately and the osteotomies were carried out in reference to anatomic landmarks. The points of measurement and their lengths are shown in Fig. 2. As pig mandibles have three mental foramina, unlike the human jaw, the middle mental foramen was used as the point of reference. Each jaw was then divided into three equal segments with the first as the most medial part and the third as the most distal one. The vertical osteotomy was made on the perpendicular line between the first 
and the second segments. The horizontal osteotomy was performed above the mandibular foramen. Following these cuts the horizontal and vertical osteotomies were connected along the oblique line. Using chisels, the osteotomy line was deepened to $2 / 3$ of the distance between the mental foramen and the alveolar rim. Splitting was achieved by introducing the $18 \mathrm{~mm}$ chisel at a right angle to the oblique line. When using the modified operation technique, an additional $5 \mathrm{~mm}$ deep osteotomy was placed at the inferior margin of the mandible (Fig. 3). The splitting process was performed manually and measured by the torque gauge, which was connected to the chisel. The direction of rotation depended on the side of the hemi-mandible, the chisel being turned clockwise in the left half of the mandible and counter clockwise in the right half of the mandible.

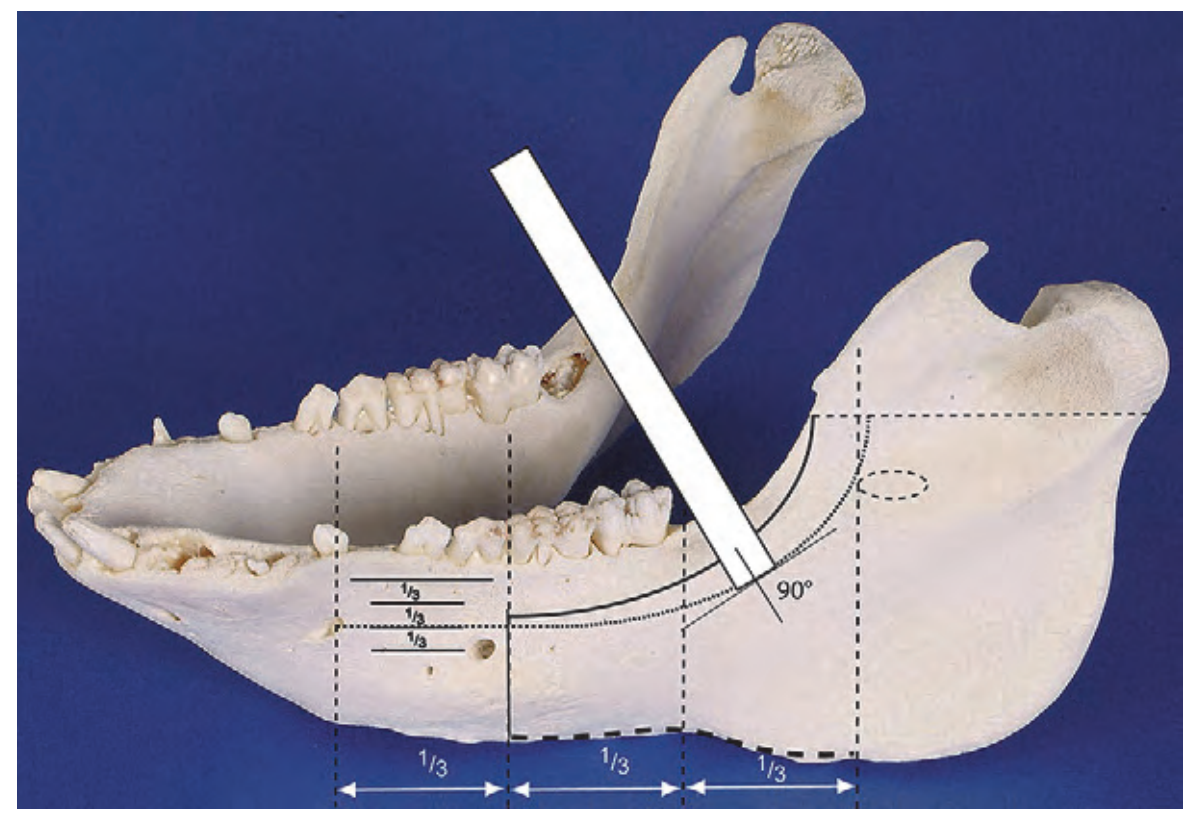

Figure 2. Pig mandible with osteotomy lines and the position of the chisel.

A digital torque gauge (Type HTG2-10, IMADA, Toyohashishi, Japan) was used to measure and record the force. It has a range of between 0 and $10 \mathrm{Nm}$ with a resolution of $0.01 \mathrm{Nm}$. The torque gauge's accuracy was $\pm 0.5 \%$ with a measuring frequency 33 times/s. The gauge was connected to a PC over a RS232 cable for graphic recording and processing using force recording software ZLINK 2, international edition, version 2.02E provided by IMADA. 


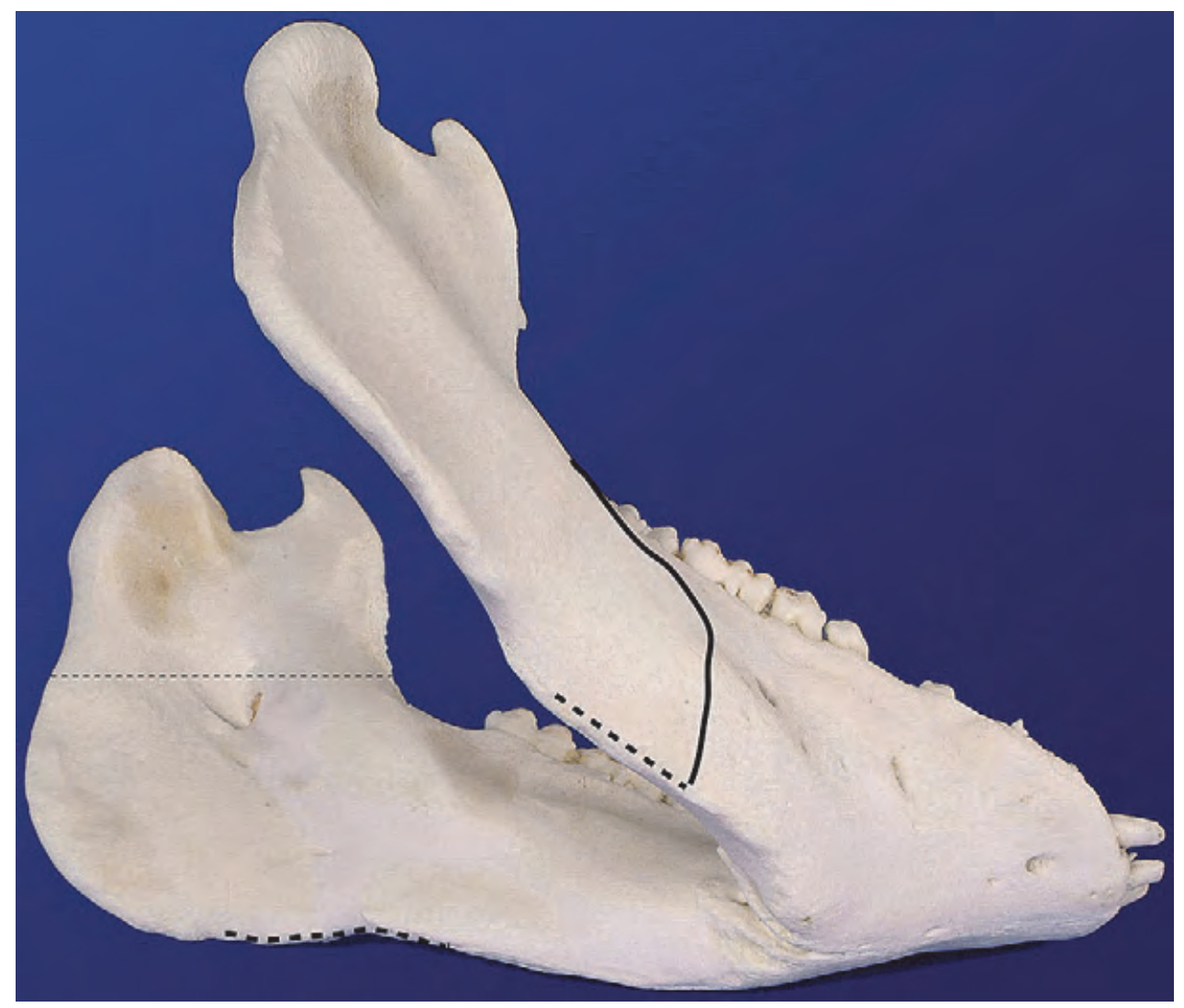

Figure 3. The additional osteotomy line at the caudal rim of the mandible.

\section{RESULTS}

To evaluate the test system's accuracy, we split a total of 30 mandibles, which were randomly assigned to one of the two techniques. Thus 16 mandibles were split the same way on both sides according to the Obwegeser-Dal Pont technique and the remaining 14 mandibles were split on both sides with the new modified technique. With the Obwegeser-Dal Pont technique we recorded an average torque of $2.26 \mathrm{Nm}$ (SD: 0.32 ) with a maximum of $2.60 \mathrm{Nm}$ and a minimum of $1.53 \mathrm{Nm}$. On the right side an average torque of $2.27 \mathrm{Nm}$ (SD: 0.33) with maximal $2.70 \mathrm{Nm}$ and minimal $1.46 \mathrm{Nm}$ was necessary to split the mandible. There was a correlation of 0.96 between both torques of the same mandible with no statistical difference between the two sides ( $t(29)=-1.06$; $p>0.05)$. When using the modified technique with an additional osteotomy at the inferior border we recorded a maximal torque of $2.56 \mathrm{Nm}$ and a minimal torque of $1.22 \mathrm{Nm}$. 
No significant difference of the average torque on the left side $(1.74 \mathrm{Nm})$ or on the right side $(1.73 \mathrm{Nm}$ ) was measured (Table 1$)$.

Table 1. Validation of the test system.

\begin{tabular}{lllll}
\hline & Left torque & Right torque & $\begin{array}{l}\text { Correlation } \\
\mathrm{p}<0,0005\end{array}$ & Paired $t$-test \\
\hline $\begin{array}{llll}\text { Obwegeser-Dal Pont } \\
\text { technique }\end{array}$ & $\begin{array}{l}2.22 \mathrm{Nm} \\
(\mathrm{SD}: 0.32)\end{array}$ & $\begin{array}{l}2.27 \mathrm{Nm} \\
(\mathrm{SD}: 0,33)\end{array}$ & 0.907 & $\mathrm{t}(29)=-1.06 ; \mathrm{p}>0.0005$ \\
Modified technique & $\begin{array}{l}1.74 \mathrm{Nm} \\
(\mathrm{SD}: 0.34)\end{array}$ & $\begin{array}{l}1.73 \mathrm{Nm} \\
(\text { SD: } 0.36)\end{array}$ & 0.955 & $\mathrm{t}(13)=0.23 ; \mathrm{p}>0.0005$ \\
& & & \\
\hline
\end{tabular}

The difference was $5.8 \%$ using the same split technique on both sides of the same jaw with a maximum difference of $9.4 \%$ and a minimum of $1.1 \%$.

In 70 pigs we compared the two different methods in the same mandible. Here we measured an average torque of $2.10 \mathrm{Nm}$ (SD: 0.54) using the method of Obwegeser-Dal Pont and an average torque of $1.50 \mathrm{Nm}$ (SD: 0.44) using the new modified technique. The new technique decreased the torque needed to split the jaw by $29.7 \%$ when compared to the classical BSSO technique. The decrease in the torque required to complete the split with the additional lower rim osteotomy was highly significant ( $t(69)=-12.68$; $p<0.05$ ) in the paired $t$-test (Table 2 ).

Table 2. Comparison of the Obwegeser-Dal Pont technique and the modified technique.

\begin{tabular}{llll}
\hline & Torque & Maximum torque & Minimal torque \\
\hline Obwegeser-Dal Pont technique & $2.10 \mathrm{Nm}$ & $4.25 \mathrm{Nm}$ & $0.90 \mathrm{Nm}$ \\
& $(\mathrm{SD}: 0.54)$ & & \\
Modified technique & $1.50 \mathrm{Nm}$ & $2.63 \mathrm{Nm}$ & $0.55 \mathrm{Nm}$ \\
& $(\mathrm{SD}: 0.44)$ & & \\
\hline
\end{tabular}

As well as the decrease in the force required to split the bone, the creation of a new groove at the lower border of the mandible improved the ability to control the splitting process. The use of the classic BSSO in our standardized technique promotes a fracture line along the mandibular canal exposing the nerve to danger of injury and increasing the risk of a bad split. Using the modified technique, the inferior split line was closer to the inferior border of the mandible, the fracture itself looked almost ideal (Fig. 4). 


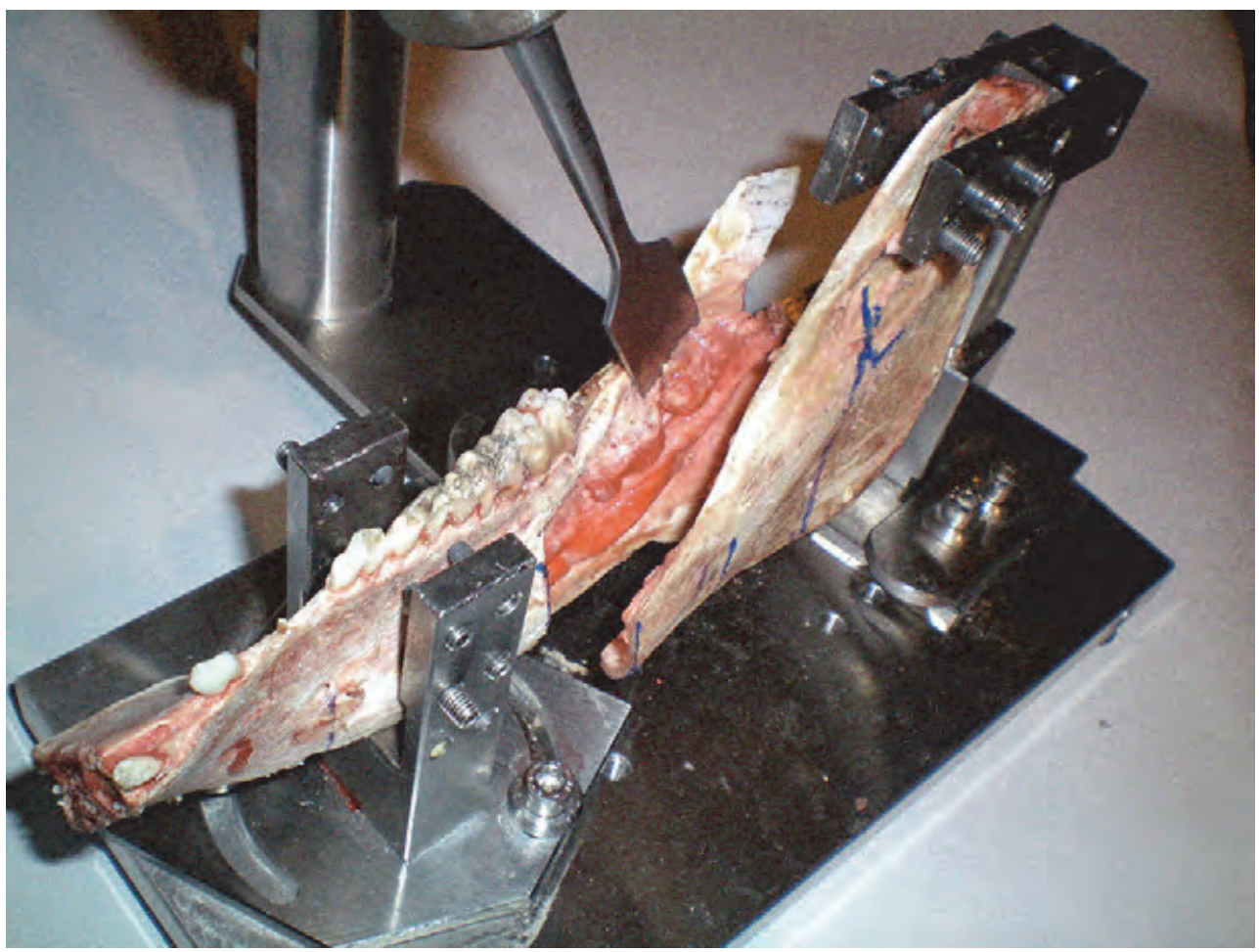

Figure 4. Split of a pig mandible in the modified technique.

\section{DISCUSSION}

The BSSO is the most common surgical procedure used in orthognathic surgery for repositioning the mandible. The large overlapping surfaces of the split segments promote good bone healing. Complications may be caused by an unfavourable fracture pattern, trauma to the neurovascular bundle, postoperative oedema or by compression injury after osteosynthesis for fixation. ${ }^{18,19}$ As an elective procedure usually performed in young, healthy patients, the complication rate should be as low as possible.

Teltzrow et al $^{20}$ identified postoperative infections, hemorrhage, inadequate osteosynthesis, damage to the alveolar nerve and bad splits as the most common complications in orthognatic surgery.

The shape and size of the mandible are variable, and in patients with skeletal disproportion these can be quite markedly abnormal. Cancellous bone at the angle of the mandible in these cases can be significantly reduced. This can complicate the splitting of the mandible and give rise to a bad split. ${ }^{21-23}$

One way of reducing the risk of a bad split is to weaken the mandible as much as possible prior to the splitting procedure with osteotomies. In the classic technique the 
osteotomy resulting in the sagittal split has to be performed by chiselling from the superior border downwards to the inferior border. The deeper the chiselling, the less is the risk of a bad split but the higher is the risk of alveolar nerve damage. As a result it is necessary to stop the chiselling before reaching the optimum depth before starting the splitting procedure, leading to a higher risk for a bad split.

By adding a further osteotomy of the cortical bone at the inferior border of the pig mandible, we weaken the bone at an otherwise stable site. Using the traditional Obwegeser-Dal Pont technique to split a pig mandible we needed an average torque of 2.1 $\mathrm{Nm}$ compared to $1.5 \mathrm{Nm}$ using the modified technique. In both procedures we stopped with chiselling above the alveolar nerve. There was difference of $0.2 \mathrm{Nm}(13 \%)$ between the first group of 30 pigs and the second group of 70 pigs for the average torque with the modified technique.

We believe that this can be explained by differences between the two groups of pigs. The two groups had been raised differently, with different diets and environmental conditions resulting in different shapes and composition of the mandibles in the two groups.

In clinical practice the ramus of the mandible frequently splits along the mandibular canal leaving a strong, full thickness, cortical piece of bone at its distal edge. Distal repositioning of the mandibular body in this situation can be difficult because the lingual cortical plate of the mandibular body cannot slide over the distal edge of mandibular ramus as a result of the remaining bone. In the modified technique we describe, there is a good chance of avoiding this problem by achieving a proper sagittal split along the whole ramus.

The fracture lines run down at the distal edge of the ramus, sparing the mandibular angle and propagate at the distal part of the mandibular body as shown in Fig. 4. The lower border osteotomy was not extended to the angle of the jaw and up to the ramus to obtain a split through the mandibular angle because, in our opinion, the surrounding anatomical structures (retromandibular vein, masseteric muscle, medial pterygoid muscle) prevent sufficient access to these areas. Furthermore the blood supply to the remaining two bone segments is even more disturbed by the necessary wide detachment of the periosteum.

In recent years ultrasonic devices (piezo surgery) have been introduced to craniomaxillofacial surgery. Gruber et $\mathrm{al}^{24}$ and Ueki et $\mathrm{al}^{25}$ described minor nerve impairment and a reduction in bleeding when using this device for osteotomies. This technique offers advantages in the reduction of alveolar nerve damage similar to the one presented above. Unfortunately piezo surgery does not guarantee a safe bone split or prevent nerve damage. ${ }^{26}$

As well as preventing bad splits the decreased force necessary to fracture the mandible lead to more superficial chiselling, resulting in a lower risk of nerve damage such as axonotmesis and neurotmesis. ${ }^{14,27-29}$ 
This study shows in pig mandibles, that it is possible to stop with chiselling above the alveolar nerve and achieving a satisfying split result by adding an inferior border osteotomy.

Caution is necessary when extrapolating the results of this study to the human mandible. Pig mandibles are larger than those of humans and containing more teeth. The body of the pig mandible is about $20 \mathrm{~cm}$ long and have 10 teeth in each quadrant, which can be grouped in three incisors, a cuspid, three premolar and three molar teeth. The mandibular angle contains more cortical bone when compared to the human mandible. A direct extrapolation of the results from pig to man is therefore not possible due to these anatomical differences The results however are encouraging enough to suggest performing this study ex-vivo in human mandibles.

If such a study were to show good results, a clinical study would need to be set up involving sophisticated neurological and radiological analysis to confirm that there are less alveolar nerve damage and fewer cases of bad splits.

The problem of how to obtain a lower border osteotomy of the mandible body as we have described in-vivo, without damaging the surrounding structures, remains to be answered. We believe it should be done with a small power saw, either rotating or oscillating.

If these observations are valid in humans, we hope to be able to decrease the most frequent complications of the BSSO including the risk of a bad split and numbness of the lip by facilitating the splitting process.

\section{CONCLUSION}

Modifying the Obwegeser-Dal Pont technique by adding an osteotomy of the inferior border of the mandible achieves predictable splitting results in pig mandibles without traumatizing the inferior alveolar nerve. This modification has yet to be performed in human mandibles and an appropriate device has to be developed to obtain an inferior border osteotomy in clinical practice.

\section{ACKNOWLEDGEMENT}

We like to thank Mrs Juliane Vogelsang, Mrs Claudia Schneider, Mr Helmut Riese and Mr Andreas Beyna for their unlimited and generous support. 


\section{REFERENCES}

1. Blair VP. Surgery and diseases of the mouth and jaws. 2nd ed. St. Louis: C.V. Mosby Company; 1913:1680.

2. Kostecka FA. Die chirurgische Therapie der Progenie. Zahnaertzl Rundsch. 1931;40:669-688.

3. Kazanjian $\mathrm{VH}$. The treatment of mandibular prognathism with special reference to edentulous patients. Oral Surg Oral Med Oral Pathol. 1951;4(6):680-688.

4. Trauner R, Obwegeser HL. Zur Operationstechnik bei der Progenie und anderen Unterkieferanomalien. Dtsch Zahn Mund Kieferheilkd. 1955;23:11-25.

5. Trauner R, Obwegeser HL. The surgical correction of mandibular prognathism and retrognathia with consideration of genioplasty. I. Surgical procedures to correct mandibular prognathism and reshaping of the chin. Oral Surg Oral Med Oral Pathol. 1957;10(7):677-689.

6. Dal Pont G. L'osteotomia retromolare per la correzione della progenia. Minerva Chir. 1959;14:11381141.

7. Hunsuck EE. A modified intraoral sagittal splitting technic for correction of mandibular prognathism. J Oral Surg. 1968;26(4):250-253.

8. Gallo WJ, Moss M, Gaul JV, Shapiro D. Modification of the sagittal ramus-split osteotomy for retrognathia. J Oral Surg. 1976;34(2):178-179.

9. Epker BN. Modifications in the sagittal osteotomy of the mandible. J Oral Surg. 1977;35(2):157-159.

10. Wolford LM, Bennett MA, Rafferty CG. Modification of the mandibular ramus sagittal split osteotomy. Oral Surg Oral Med Oral Pathol. 1987;64(2):146-155.

11. Wolford LM, Davis WM. The mandibular inferior border split: a modification in the sagittal split osteotomy. J Oral Maxillofac Surg. 1990;48(1):92-94.

12. Markiewicz MR, Margarone JE3. Modified channel retractor for the sagittal split ramus osteotomy: a technical note. J Craniomaxillofac Surg. 2008;36(5):269-272.

13. Mommaerts MY. Endoscopically assisted sagittal split osteotomy for mandibular lengthening: technical note and initial experience. J Craniomaxillofac Surg. March 2010.

14. August M, Marchena J, Donady J, Kaban L. Neurosensory deficit and functional impairment after sagittal ramus osteotomy: a long-term follow-up study. J Oral Maxillofac Surg. 1998;56(11):1231-1235.

15. Kriwalsky MS, Maurer P, Veras RB, Eckert AW, Schubert J. Risk factors for a bad split during sagittal split osteotomy. Br J Oral Maxillofac Surg. 2008;46(3):177-179.

16. Ylikontiola L, Moberg K, Huumonen S, Soikkonen K, Oikarinen K. Comparison of three radiographic methods used to locate the mandibular canal in the buccolingual direction before bilateral sagittal split osteotomy. Oral Surgery, Oral Medicine, Oral Pathology, Oral Radiology, and Endodontology. 2002;93(6):736-742.

17. Tsuji Y, Tsuji Y, Muto T, et al. Computed tomographic analysis of the position and course of the mandibular canal: relevance to the sagittal split ramus osteotomy. Int J Oral Maxillofac Surg. 2005;34(3):243-246.

18. Jones DL, Wolford LM, Hartog JM. Comparison of methods to assess neurosensory alterations following orthognathic surgery. Int J Adult Orthodon Orthognath Surg. 1990;5(1):35-42.

19. Nakagawa K, Ueki K, Takatsuka S, Takazakura D, Yamamoto E. Somatosensory-evoked potential to evaluate the trigeminal nerve after sagittal split osteotomy. Oral Surg Oral Med Oral Pathol Oral Radiol Endod. 2001;91(2):146-152.

20. Teltzrow T, Kramer F-J, Schulze A, Baethge C, Brachvogel P. Perioperative complications following sagittal split osteotomy of the mandible. J Craniomaxillofac Surg. 2005;33(5):307-313.

21. Turvey TA. Intraoperative complications of sagittal osteotomy of the mandibular ramus: incidence and management. J Oral Maxillofac Surg. 1985;43(7):504-509.

22. van Merkesteyn RJPR, Groot RH, van Leeuwaarden R, Kroon FH. Intra-operative complications in sagittal and vertical ramus osteotomies. Int J Oral Maxillofac Surg. 1987;16(6):665-670.

23. Panula K, Finne K, Oikarinen K. Incidence of complications and problems related to orthognathic surgery: A review of 655 patients. J Oral Maxillofac Surg. 2001;59(10):1128-1136. 


\section{Chapter 3}

24. Gruber RM, Gruber RM, Kramer F-J, et al. Ultrasonic surgery--an alternative way in orthognathic surgery of the mandible. A pilot study. Int J Oral Maxillofac Surg. 2005;34(6):590-593.

25. Ueki K, Ueki K, Nakagawa K, et al. Use of the Sonopet ultrasonic curettage device in intraoral vertical ramus osteotomy. Int J Oral Maxillofac Surg. 2007;36(8):745-747.

26. Geha HJ, Gleizal AM, Nimeskern NJ, Beziat J-L. Sensitivity of the inferior lip and chin following mandibular bilateral sagittal split osteotomy using Piezosurgery. Plast Reconstr Surg. 2006;118(7):1598-1607.

27. Akal UK, Sayan NB, Aydogan S, Yaman Z. Evaluation of the neurosensory deficiencies of oral and maxillofacial region following surgery. Int J Oral Maxillofac Surg. 2000;29(5):331-336.

28. Al-Bishri A, Barghash Z, Barghash Z, et al. Neurosensory disturbance after sagittal split and intraoral vertical ramus osteotomy: as reported in questionnaires and patients' records. Int J Oral Maxillofac Surg. 2005;34(3):247-251.

29. Colella G, Cannavale R, Vicidomini A, Lanza A. Neurosensory disturbance of the inferior alveolar nerve after bilateral sagittal split osteotomy: a systematic review. J Oral Maxillofac Surg. 2007;65(9):17071715. 


\section{Chapter}

\section{Modification of the bilateral sagittal split osteotomy (BSSO) in a study using pig mandibles}

P. Schön, M. Frotscher, G. Eggeler, P.A.W.H. Kessler, K.-D. Wolff, R. Böckmann

Published in International Journal of Oral and Maxillofacial Surgery, 2011;40:516-520 


\section{ABSTRACT}

In a bilateral sagittal split osteotomy (BSSO) mechanical irritation of the inferior alveolar nerve (IAN) (e.g. by chiselling) should be avoided to prevent neural damage. A modification of the Obwegeser-Dal Pont operation technique was studied by splitting 100 pig mandibles ex-vivo. An additional osteotomy at the caudal border of the mandible was used to facilitate the sagittal split by means of a locus of minor resistance. The chisel was inserted distal to the second molar and far away from the IAN. The mandible was split by torque. The modified technique reduced the required torque to split the mandible about 30\% compared with the original technique (paired $t$-test, $\mathrm{t}(69)=-12.89$; $p<0.05) .75 \%$ of all mandibles split by the modified technique were classified as bad splits compared with $100 \%$ using the original technique using the same protocol without the additional osteotomy. 


\section{INTRODUCTION}

Damage to the inferior alveolar nerve (IAN) is one of the most frequent complications of bilateral sagittal split osteotomy (BSSO). ${ }^{1-3}$ Sensory deficits at least 1 year after the operation are reported in $13-40 \%$ of all patients. Attempts to solve this problem have been made since its introduction in 1953 by Obwegeser and Trauner. ${ }^{4,5}$ Hunsack, Epker and Dal Pont altered the basic technique to prevent unfavourable bone splitting (bad splits), to avoid pseudarthrosis and to avoid the IAN..$^{6-8}$

Partial lip and chin numbness is caused by axonotmesis, ${ }^{9}$ anaesthesia by neurotmesis. Although, in most cases, it recovers within a year, ${ }^{10,11}$ sensibility is still a problem in orthognathic patients after surgery. Other infrequent problems are unfavourable splits and pseudarthrosis. Unfavourable or bad splits are often related to insufficient osteotomies, which can be related to anatomical aberrations, or to the use of superficial osteotomies in an attempt to protect the IAN..$^{12}$ Improved preoperative diagnostics did not improve the complication rate. ${ }^{13,14}$

The aim of this animal cadaver study was to examine the effect of an additional osteotomy of the caudal border of the mandible in a BSSO conducted using the Obwegeser-Dal Pont technique. The technique was modified to maintain a safe distance from the neurovascular bundle during the entire operation. By creating an additional locus of minor resistance the authors anticipated a favourable split despite more superficial chiselling of the remaining osteotomy lines.

\section{MATERIAL AND METHODS}

The Obwegeser-Dal Pont operation was standardized in the following way. Each jaw was measured and major anatomical structures were marked (Fig. 1). Unlike the human mandible, there are three mental foramens in pig mandibles. The middle mental foramen was chosen as the point of reference. The mandibular body was divided into three segments. The lingual osteotomy was made above the mandibular foramen through the cortical bone. The buccal cut through the cortical bone was performed on the perpendicular line between the first and the second segment distal to the mental foramen. The two osteotomies were connected by a third osteotomy along the oblique line. By chiselling, the crestal osteotomy was deepened to two-thirds of the distance between the mental foramen and the alveolar ridge. An $18 \mathrm{~mm}$ wide osteotome was inserted distal to the last molar tooth no deeper than two-thirds of the distance between the mental foramen and the alveolar ridge. The mandible was sagittally split by torquing with the osteotome in one direction only. In the left mandible, the osteotome was wrenched clockwise and there was a counter clockwise rotation in the right body of the mandible. In the modified operation technique, an additional osteotomy, $5 \mathrm{~mm}$ deep, was added at the caudal border of the mandible (Fig. 2). 


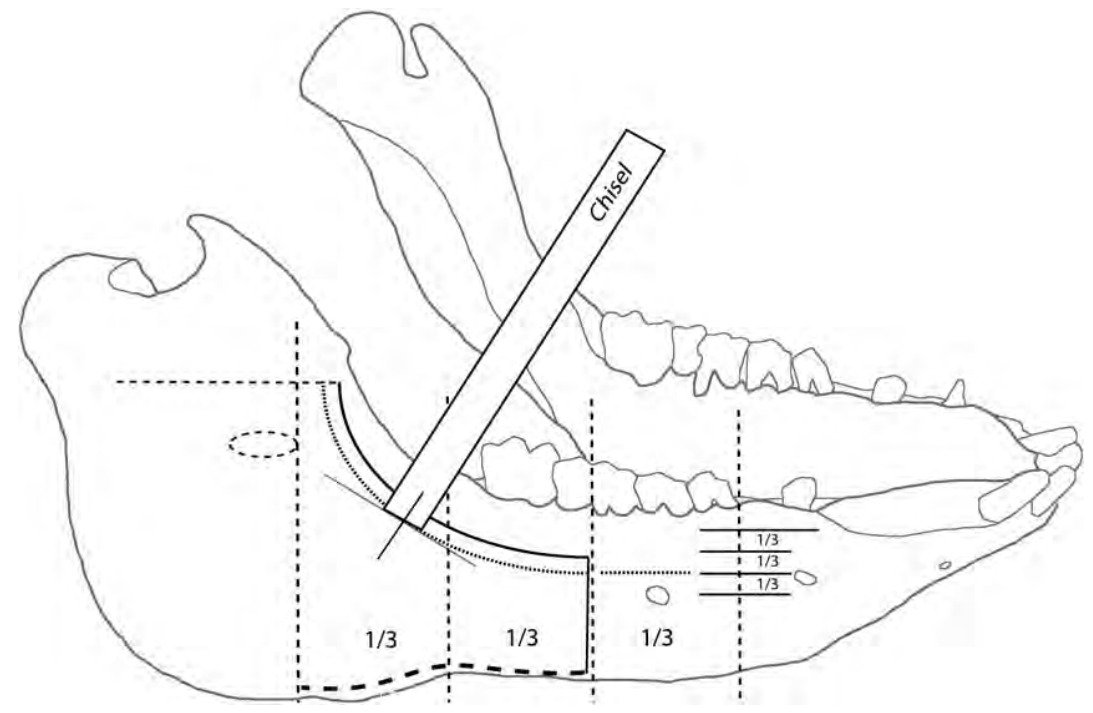

Figure 1. Pig mandible with the osteotomies and their positions. Note the added osteotomy at the caudal rim. The osteotome is placed at a right angle to the tangent of the oblique line. Its depth is two-thirds of the distance between the alveolar rim and the mental foramen.

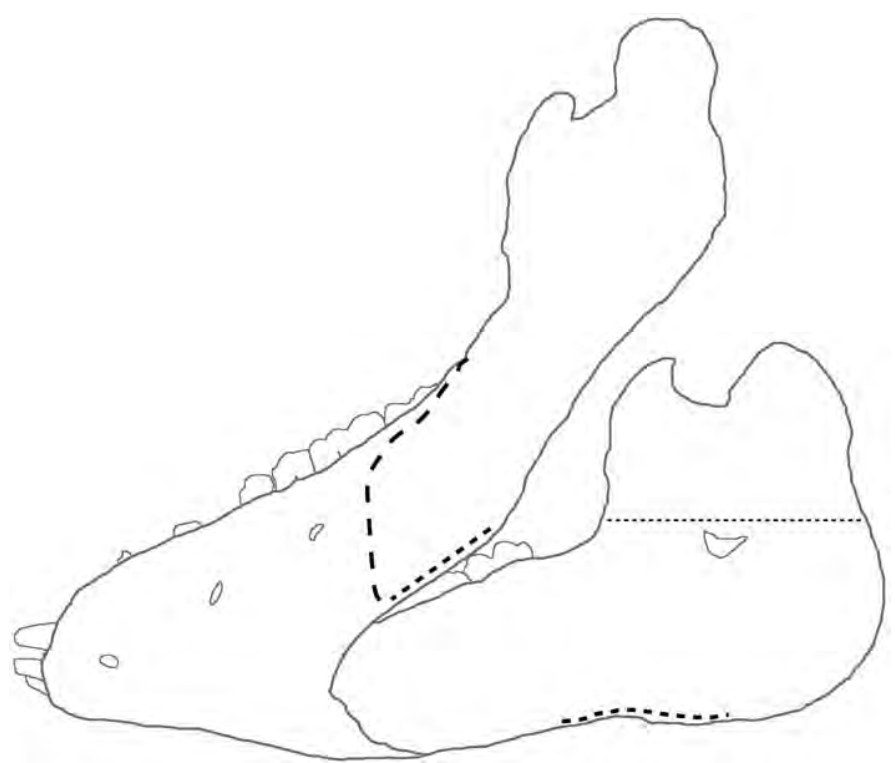

Figure 2. Pig mandible as seen from below. The thicker dotted line represents the added osteotomy at the caudal rim of the mandible.

A test system made from stainless steel was constructed, which contained a fixation for one half of a pig mandible and a torque gauge. The mandible was fixed rigidly at the condyle and at the mental part of the jaw. The distal part of the mandible was moveable 
in all three dimensions. The torque gauge holder was freely moveable, so it was always possible to put the osteotome in the right position. The digital torque gauge HTG2-10 (IMADA, Toyohashishi, Japan) was used to record the force (Fig. 3) necessary to split the mandible. It ranged between 0 and $10 \mathrm{Nm}$ with a resolution of $0.01 \mathrm{Nm}$. The accuracy of the torque gauge was $\pm 0.5 \%$ and the measuring frequency was 33 times per second. The gauge was connected to a PC over a RS232 cable for data recording and processing using ZLINK 2 software (international edition, version 2.02E delivered by IMADA).

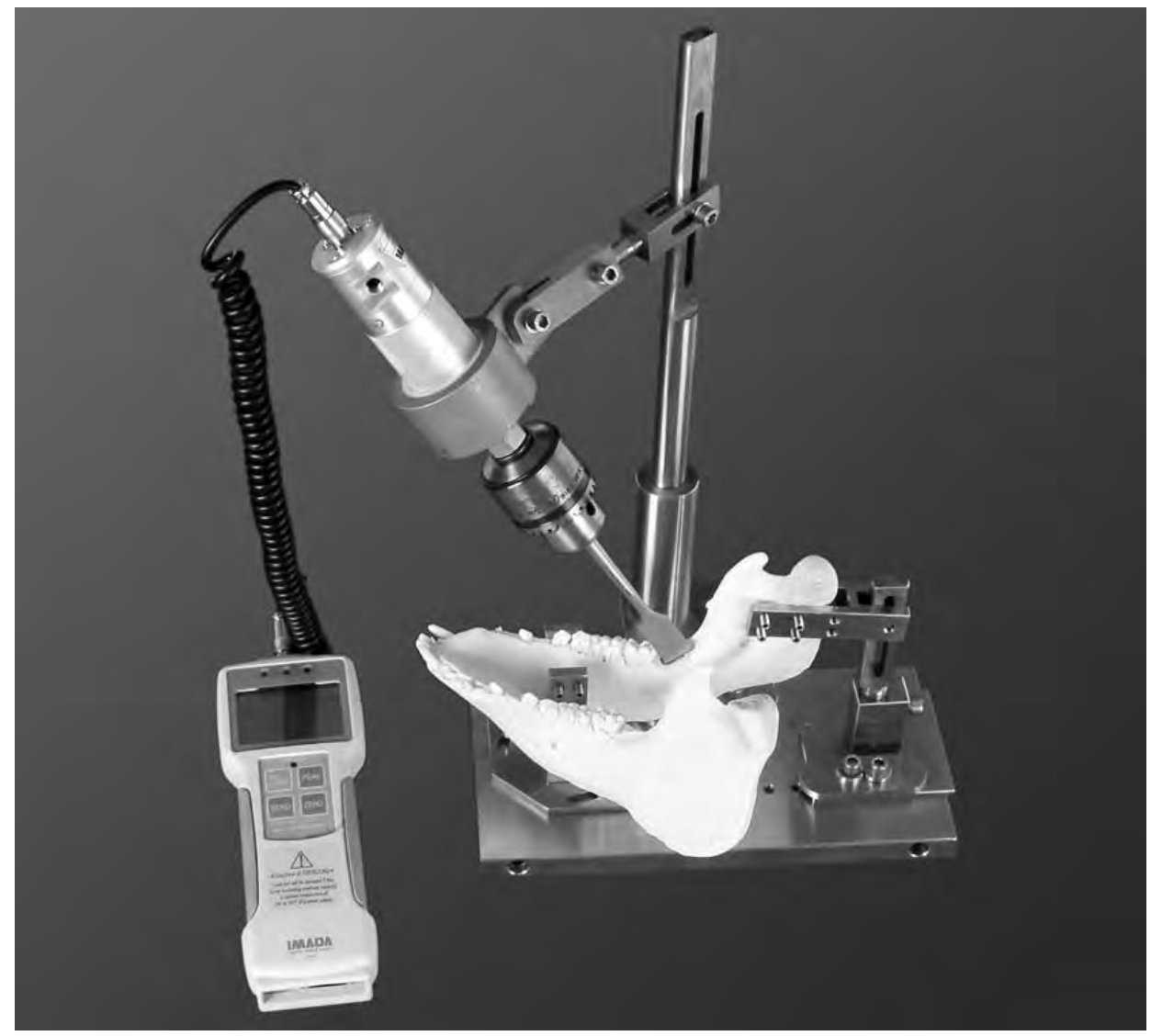

Figure 3. Test system with mounted pig mandible. The osteotome is in place and connected to the datarecording device.

100 Pig mandibles (Sus scrofa domestica, Schlachthof Bochum GmbH, Germany) were available in two batches of 30 and 70.30 mandibles were used to validate the test system, and 70 were used to study the different operation techniques.

To validate the test system, 30 adult pig mandibles were halved along the median line and both halves were used for the split osteotomy. The operation technique was randomly assigned to the Obwegeser-Dal Pont technique or the modified technique 
implementing the caudal border osteotomy. 70 pig mandibles were used to compare the different splitting procedures. The mandibles were halved and randomly chosen to be split using the Obwegeser-Dal Pont technique or the modified technique.

\section{RESULTS}

The first batch of 30 pig mandibles was used to validate the test system, including 16 mandibles that were split according the Obwegeser-Dal Pont technique and 14 that were split with the modified technique. The correlation between both sides in the same mandible for the modified technique was 0.91 with an average torque of $1.74 \mathrm{Nm}$ (SD: 0.34) on the left side and $1.74 \mathrm{Nm}$ (SD: 0.36) on the right side. For the Obwegeser-Dal Pont technique the correlation was 0.96 with an average recorded torque of $2.22 \mathrm{Nm}$ (SD: 0.32) on the left side and $2.27 \mathrm{Nm}$ (SD: 0.33) on the right side.

The average correlation in both techniques was 0.96 . The hypothesis of different torques was rejected significantly (paired $t$-test, $\mathrm{t}(29)=-1.06 ; p>0.05$ ). In general the aberration was $6 \%$ using the same split technique on both sides in the same mandibular body. The maximum aberration was $9 \%$, the minimum $1 \%$.

Another 70 mandibles were used to compare both methods in the same mandible. An average torque of $2.12 \mathrm{Nm}$ (SD: 0.57 , max: $4.25 \mathrm{Nm}$, min: $0.90 \mathrm{Nm}$ ) was measured in the Obwegeser-Dal Pont procedure and an average torque of $1.51 \mathrm{Nm}$ (SD: 0.46, max. $2.62 \mathrm{Nm}$, min. $0.55 \mathrm{Nm}$ ) was measured in the modified technique. This technique reduced the torque needed to split the jaw by $30 \%$ compared with the classic BSSO technique. The torque loss with the additional caudal border osteotomy was strongly significant $(\mathrm{t}(69)=-12.89 ; p<0.05)$ in the paired $t$-test.

Comparing the split results of both techniques in the standardized operation protocol there was a $100 \%$ split through the mandibular canal in the Obwegeser-Dal Pont technique (Fig. 4, type A). Using the modified technique, $75 \%$ of the mandibles fractured through the caudal border (Fig. 4, type B), the remaining $25 \%$ of the cases split according to type $A$ fracture lines.

\section{DISCUSSION}

BSSO is the leading surgical technique in orthognathic surgery for repositioning the mandible. It supports bone healing due to the huge overlapping surfaces of the split segments. The creation of these overlap- ping segments puts the IAN at risk. This complication might be caused by direct mechanical damage during surgery, postoperative oedema or by compression after fixation of the segments. ${ }^{15,16}$ As an elective intervention usually performed on young, healthy patients, the complication rate should be as low as possible. 


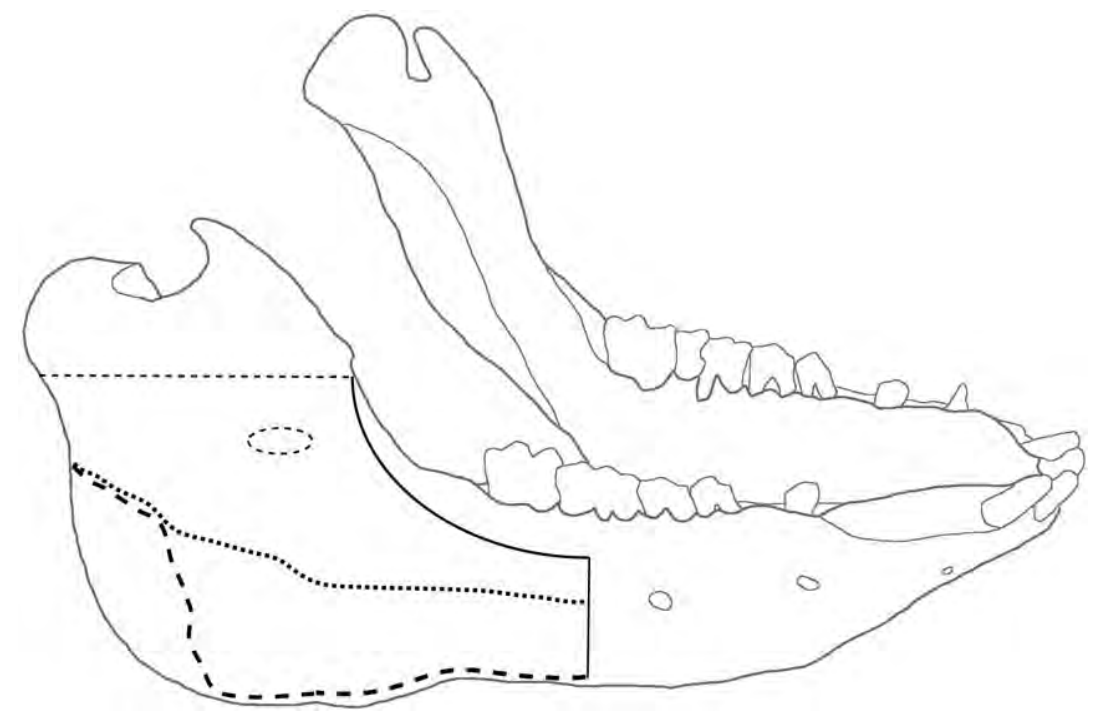

Figure 4. The fracture lines: the fine dotted line represents the fractures achieved (type A) by the ObwegeserDal Pont technique, the thicker dotted line shows the fractures (type B) achieved with the modified technique.

Applying an additional osteotomy at the caudal border of the mandible decreases the likelihood of these complications. Less force is needed to split the mandible in a predictable way. A major advantage of the new technique is that it allows very gentle and superficial chiselling, leaving the IAN untouched. The authors stopped chiselling far above the nerve, which prevents axonotmesis and neuotmesis, even though the fracture lines were more precise and predictable. Teerijoki-Oksa et al ${ }^{17}$ examined the electrophysiological alterations of the IAN during the different steps of the SSO. They reported a high risk of deterioration during the medial opening if there was prolonged compression and stretching of the nerve. More severe and immediate changes were obtained if the nerve was mechanically altered, either during the vertical cut or during the splitting process with the most risky moment being when chiselling in the retromolar region. This is the manoeuvre that is spared in the modified technique. TeerijokiOksa et $\mathrm{al}^{18}$ gave no data about the correlation between long lasting clinicalneurological and electrophysiological alterations, nor about the chance of neurological recovery after severe nerve compression during medial opening. Other authors 3,19,20 found strong links between sensitive deficits and manipulations of the IAN. The authors anticipate less damage to the neurosensory function of the IAN with the new technique because the IAN is not touched during the procedure.

It is difficult to slice the inferior border of the mandible in-vivo. Space and overview are limited by the intraoral approach. Ultrasonic technology may help. Ultrasonic devices (piezo surgery) have been introduced to cranio-maxillofacial surgery. Gruber et al and Ueki et al described minor nerve impairment and a reduction in bleeding when 
using this device for osteotomies. ${ }^{21,22}$ The advantage of reduced nerve damage is comparable to the new splitting technique described above. Piezo surgery does not guarantee a safe bone split and is time consuming.

Another possibility is the use of the Withington osteotomes. ${ }^{23}$ These were designed by Simpson to facilitate horizontal osteotomies but also aid osteotomy of the inferior border. The osteotomy was achieved using a triangular, v-shaped osteotome without soft tissue protection provided by the instruments themselves.

A rotating or oscillating saw could be used. Wolford and Davis ${ }^{24}$ developed a reciprocating saw to cut the inferior border of the mandible in 1990. Using this they achieved mandible splitting without malleting. They described a more predictable split with fewer complications, but provide no detailed data. The saw has no protection against the surround tissue containing the facial vein and artery and the marginal branch of the facial nerve. According to the authors, this technique should only be used by experienced surgeons to avoid complications.

Although the fracture lines could be considered to be sufficient as shown in Fig. 4, the angle and the ascending ramus are not included in the mandibular split. The authors consider that the anatomical structures (retromandibular vein, masseter muscle, and medial pyterigoid muscle) in this area are too close to allow the safe use of a cutting device and it leaves a huge part of the mandible denudated.

Pig mandibles are bigger than human ones, and contain more teeth with more roots. The region of the mandibular angle contains less cancellous bone and more cortical bone. The variation of the standard deviation expresses the immense individual difference in the shape and thickness of bone, which is also evident in human surgery.

\section{CONCLUSION}

The authors consider that provided they keep away from the IAN using the modification of the Obwegeser-Dal Pont technique they expect a better neurosensitive outcome. Clinical studies are mandatory to prove these expectations.

\section{FUNDING}

This study was granted by the 'German Research Fund', Special Research Centre 459. 


\section{REFERENCES}

1. Colella G, Cannavale R, Vicidomini A, Lanza A. Neurosensory disturbance of the inferior alveolar nerve after bilateral sagittal split osteotomy: a systematic review. J Oral Maxillofac Surg. 2007;65(9):17071715.

2. Nesari S, Nesari S, Kahnberg KE, Rasmusson L, Rasmusson L. Neurosensory function of the inferior alveolar nerve after bilateral sagittal ramus osteotomy: a retrospective study of 68 patients. Int J Oral Maxillofac Surg. 2005;34(5):495-498.

3. Westermark $\mathrm{AH}$, Bystedt $\mathrm{H}$, Konow von L. Inferior alveolar nerve function after mandibular osteotomies. Br J Oral Maxillofac Surg. 1998;36(6):425-428.

4. Trauner R, Obwegeser $\mathrm{HL}$. The surgical correction of mandibular prognathism and retrognathia with consideration of genioplasty. I. Surgical procedures to correct mandibular prognathism and reshaping of the chin. Oral Surg Oral Med Oral Pathol. 1957;10(7):677-689.

5. Trauner R, Obwegeser HL. Zur Operationstechnik bei der Progenie und anderen Unterkieferanomalien. Dtsch Zahn Mund Kieferheilkd. 1955;23:11-25.

6. Dal Pont G. Retromolar osteotomy for the correction of prognathism. J Oral Surg Anesth Hosp Dent Serv. 1961;19:42-47.

7. Epker BN. Modifications in the sagittal osteotomy of the mandible. J Oral Surg. 1977;35(2):157-159.

8. Hunsuck EE. A modified intraoral sagittal splitting technic for correction of mandibular prognathism. J Oral Surg. 1968;26(4):250-253.

9. Becelli R, Renzi G, Carboni A, Cerulli G, Gasparini G. Inferior alveolar nerve impairment after mandibular sagittal split osteotomy: an analysis of spontaneous recovery patterns observed in 60 patients. J Craniofac Surg. 2002;13(2):315-320.

10. August M, Marchena J, Donady J, Kaban L. Neurosensory deficit and functional impairment after sagittal ramus osteotomy: a long-term follow-up study. J Oral Maxillofac Surg. 1998;56(11):1231-1235.

11. Teerijoki-Oksa T, Jääskeläinen SK, Forssell K, Forssell H. Recovery of nerve injury after mandibular sagittal split osteotomy. Diagnostic value of clinical and electrophysiologic tests in the follow-up. Int J Oral Maxillofac Surg. 2004;33(2):134-140.

12. Kriwalsky MS, Maurer P, Veras RB, Eckert AW, Schubert J. Risk factors for a bad split during sagittal split osteotomy. Br J Oral Maxillofac Surg. 2008;46(3):177-179.

13. Tsuji Y, Tsuji Y, Muto T, et al. Computed tomographic analysis of the position and course of the mandibuIar canal: relevance to the sagittal split ramus osteotomy. Int J Oral Maxillofac Surg. 2005;34(3):243-246.

14. Ylikontiola L, Moberg K, Huumonen S, Soikkonen K, Oikarinen K. Comparison of three radiographic methods used to locate the mandibular canal in the buccolingual direction before bilateral sagittal split osteotomy. Oral Surgery, Oral Medicine, Oral Pathology, Oral Radiology, and Endodontology. 2002;93(6):736-742.

15. Jones DL, Wolford LM, Hartog JM. Comparison of methods to assess neurosensory alterations following orthognathic surgery. Int J Adult Orthodon Orthognath Surg. 1990;5(1):35-42.

16. Nakagawa K, Ueki K, Takatsuka S, Takazakura D, Yamamoto E. Somatosensory-evoked potential to evaluate the trigeminal nerve after sagittal split osteotomy. Oral Surg Oral Med Oral Pathol Oral Radiol Endod. 2001;91(2):146-152.

17. Teerijoki-Oksa T, Jääskeläinen SK, Forssell K, et al. Risk factors of nerve injury during mandibular sagittal split osteotomy. Int J Oral Maxillofac Surg. 2002;31(1):33-39.

18. Teerijoki-Oksa T, Jääskeläinen SK, Virtanen A, Forssell H. An evaluation of clinical and electrophysiologic tests in nerve injury diagnosis after mandibular sagittal split osteotomy. Int J Oral Maxillofac Surg. 2003;32(1):15-23.

19. Fridrich KL, Holton TJ, Pansegrau KJ, Buckley MJ. Neurosensory recovery following mandibular bilateral sagittal split osteotomy. J Oral Maxillofac Surg. 1995;53(11):1300-1306.

20. Ylikontiola L. Factors affecting neurosensory disturbance after mandibular bilateral sagittal split osteotomy. J Oral Maxillofac Surg. 2000;58:1234-1239. 


\section{Chapter 4}

21. Gruber RM, Gruber RM, Kramer F-J, et al. Ultrasonic surgery-an alternative way in orthognathic surgery of the mandible. A pilot study. Int J Oral Maxillofac Surg. 2005;34(6):590-593.

22. Ueki K, Ueki K, Nakagawa K, et al. Use of the Sonopet ultrasonic curettage device in intraoral vertical ramus osteotomy. Int J Oral Maxillofac Surg. 2007;36(8):745-747.

23. Sanders KJ. The Withington osteotomes: an aid to sagittal split osteotomies. Br J Oral Maxillofac Surg. 1997;35(1):52-53.

24. Wolford LM, Davis WM. The mandibular inferior border split: a modification in the sagittal split osteotomy. J Oral Maxillofac Surg. 1990;48(1):92-94. 


\section{Chapter}

\section{In-vitro comparison of the sagittal split osteotomy with and without inferior border osteotomy}




\section{ABSTRACT}

Objective: By adding an osteotomy of the inferior border of the mandibular body to the classic sagittal split osteotomy, the authors expected to prevent unfavorable splits and damage to the inferior alveolar nerve.

Material and methods: Thirty-five human mandibles were used to perform 70 sagittal split osteotomies as an in-vitro study. Conducted as a split-mouth model, each mandible was split at the midline. One side of the mandible was split using the traditional Obwegeser-Dal Pont technique, and the other side was split in the same manner with an additional osteotomy of the inferior mandible border. The torque used to split the mandible was measured, and the fracture line of the mandible was recorded.

Results: The average torque associated with the original technique was $1.38 \mathrm{Nm}$ (standard deviation, $0.60 \mathrm{Nm}$ ), with a fracture line along the mandibular canal. The average torque required to split the hemimandible with the modified technique was $1.02 \mathrm{Nm}$ (standard deviation, $0.50 \mathrm{Nm}$ ), a significant $(p<.001)$ difference, with a fracture line parallel to the posterior ramus of the mandible. The fracture pattern depended significantly on the technique used $(p<.001)$, but not on the applied torque force.

Conclusion: By adding an osteotomy of the inferior mandibular border to the sagittal split osteotomy, less torque was needed to split the mandible. The fracture line was more predictable, even when all the surgical manipulations were performed at a safe distance from the inferior alveolar nerve. 


\section{INTRODUCTION}

The era of modern orthognathic surgery began with the introduction of the bilateral sagittal split osteotomy (BSSO) by Hugo Obwegeser ${ }^{1}$ in 1953 . Since then, this operation has defined perceptions of maxillofacial surgery more than any other procedure. Nevertheless, the basic idea of BSSO, which is to fracture the mandible by a splitting maneuver to preserve the inferior alveolar nerve (IAN), has been modified multiple times according to current needs. ${ }^{2-5}$ However, most of the tackled complications, such as excessive swelling, condylar displacement and postoperative relapse, unfavorable split, or damage to the IAN, remain. ${ }^{6-8}$

One idea to prevent a bad split or damage to the IAN by extended mechanical manipulation during the splitting manoeuver is the lower or inferior border osteotomy. ${ }^{3,4}$ The authors proved its usability in a prior study in pig mandibles. ${ }^{9}$ In the present study, the authors took this idea a step further by using human mandibles for an in-vitro study. The hypothesis was that by adding an inferior border osteotomy to the Obwegeser-Dal Pont technique, the splitting procedure would result in a more defined fracture. Compared with the Obwegeser-Dal Pont technique performed on the same mandible, the authors expected less torque force for the split. These 2 advantages should be related to the more extended loci of minor resistance.

\section{MATERIAL AND METHODS}

In this study, 35 formalin-fixed human mandibles obtained from the Department of Anatomy, Ruhr University (Bochum, Germany) were used. They had been dissected from the skull base by a cut through the temporomandibular joint. The soft tissue was completely removed. The dentition was classified according to Kennedy ${ }^{10}$ as follows: complete dentition, 9 jaws; Kennedy type I, 11 jaws; Kennedy type II, 7 jaws; Kennedy type III, 5 jaws; and edentulous, 4 jaws.

A self-constructed rack was used to fixate the jaws for measurement (Fig. 1). The test system had been validated previously. ${ }^{9}$ The fixture for the condyle was rigid, whereas the fixture for the proximal part of the mandible allowed for movements in all 3 dimensions. A gauge with an attached chisel was mounted on the rack. The construction of the rack allowed for the chisel to be directed to the desired position to perform the split.

The HTG2-10 gauge developed by IMADA (Toyohashishi, Japan) was used. Its accuracy was $\pm 0.5 \%$, with a measurement frequency of 33 times per second. The applied force was recorded with a personal computer using ZLINK 2.02E software (international edition; IMADA). 


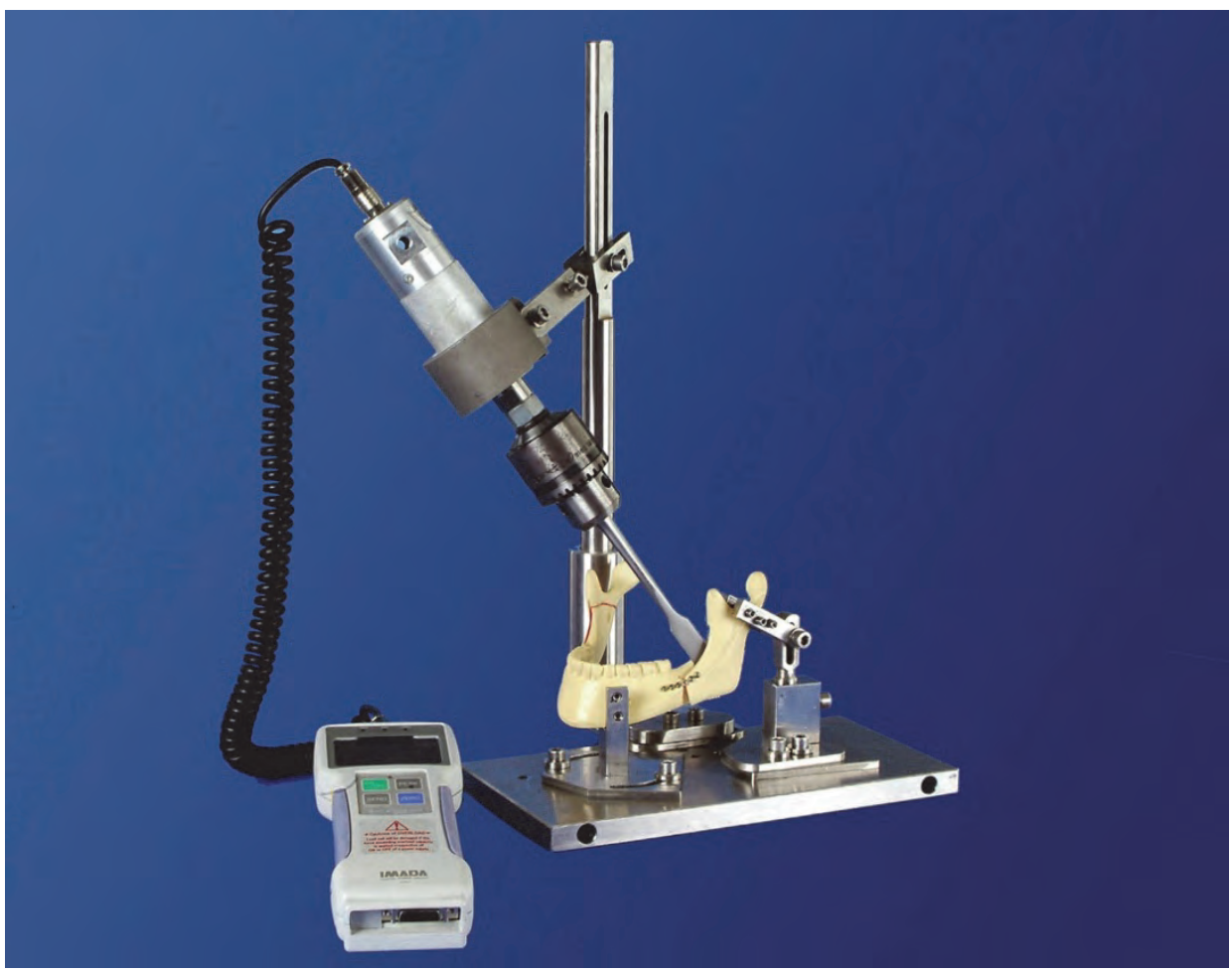

Figure 1 . The rack holding a plastic mandible, with the chisel in place and connected to the gauge.

\section{SURGICAL TECHNIQUE}

Each jaw was split in half through the median line as a split-mouth model. Each half of the same mandible was fixed on the rack to perform a sagittal split according to the Obwegeser-Dal Pont method or in the modified manner. Before starting the split, each half was randomly assigned to the original or the modified technique.

The splitting procedure was standardized according to the Obwegeser-Dal Pont method (Fig. 2). A perpendicular line through the mandibular foramen and a second line through the mental foramen were used to determine the overall length. The vertical osteotomy through the cortical bone was performed at two thirds the total length distal to the mental foramen. The horizontal osteotomy was made above the mandibular foramen through the cortical bone. These lines were connected by an osteotomy alongside the oblique line. A Lindemann burr was used for all osteotomies. The distance between the alveolar crest and the mental foramen was measured along a perpendicular line that ran through the mental foramen and at right angle to the mandibular base. $\mathrm{A}$ chisel was driven into the mandibular body in the craniocaudal direction no deeper than two thirds of that length, and the entire osteotomy was deepened. An osteotome with 
an 18-mm width was inserted distal to the second molar to this depth at an angle of $45^{\circ}$, and the mandible was successfully split by clockwise rotation to the left side and counterclockwise rotation to the right side. Then, the maximum torque force that was needed to split the mandible was recorded. The other side of the same jaw was operated on in a modified manner by adding an osteotomy at the inferior border of the mandibular body from the vertical cut to the mandibular angle.

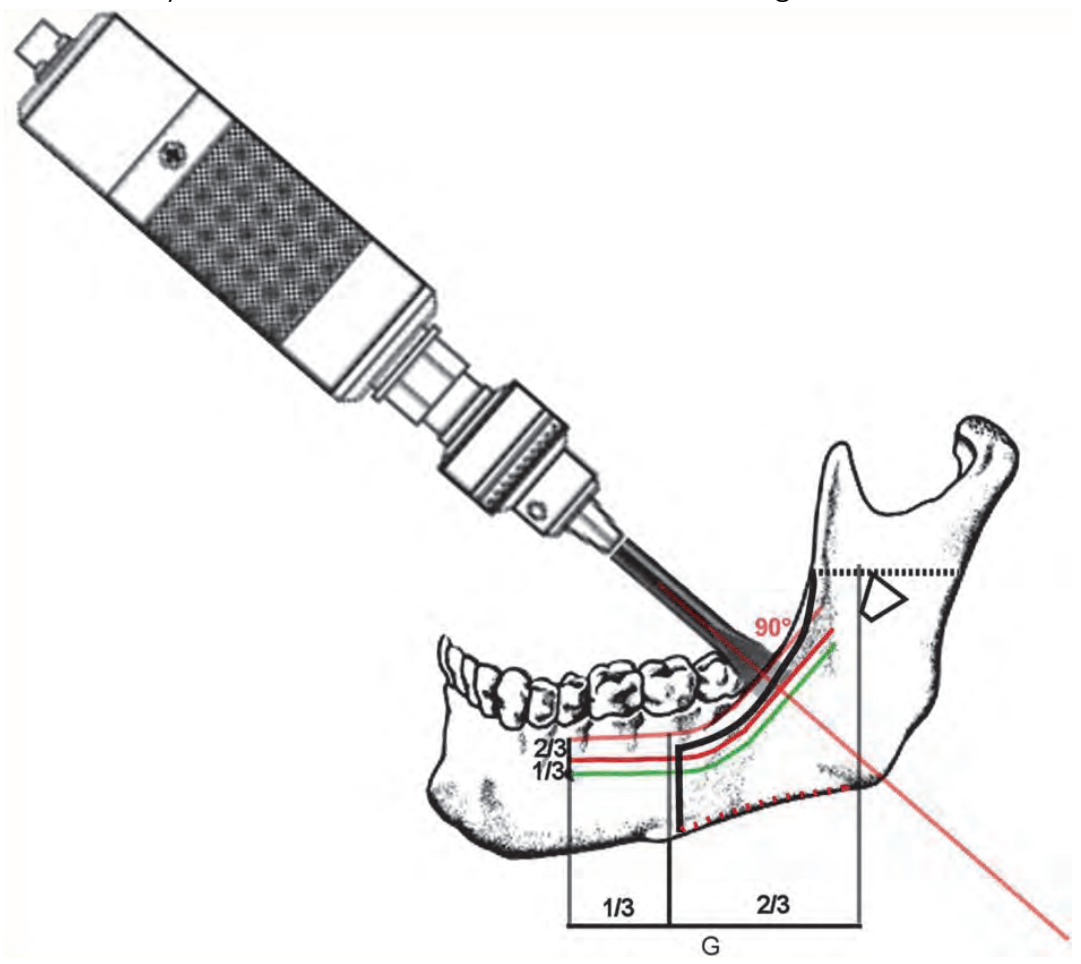

Figure 2. Drawing of a hemimandible showing all dimensions used in the sagittal split osteotomy protocol. An additional inferior border osteotomy is displayed (dotted red line).

\section{Collected Data}

The maximum torque force that was needed to split the mandible was obtained by recording the applied torque forces continuously during the splitting procedure.

After the 2 splits, the split patterns were traced relative to the mandibular body and the neurovascular bundle and were classified according to Plooij et al ${ }^{11}$ as types 1 to 4 . Type 1 represented a Hunsuck-like lingual fracture, type 2 represented an Obwegeserlike fracture, and type 3 coursed along the mandibular canal. Type 4 represented an unfavorable fracture (Fig. 3). 

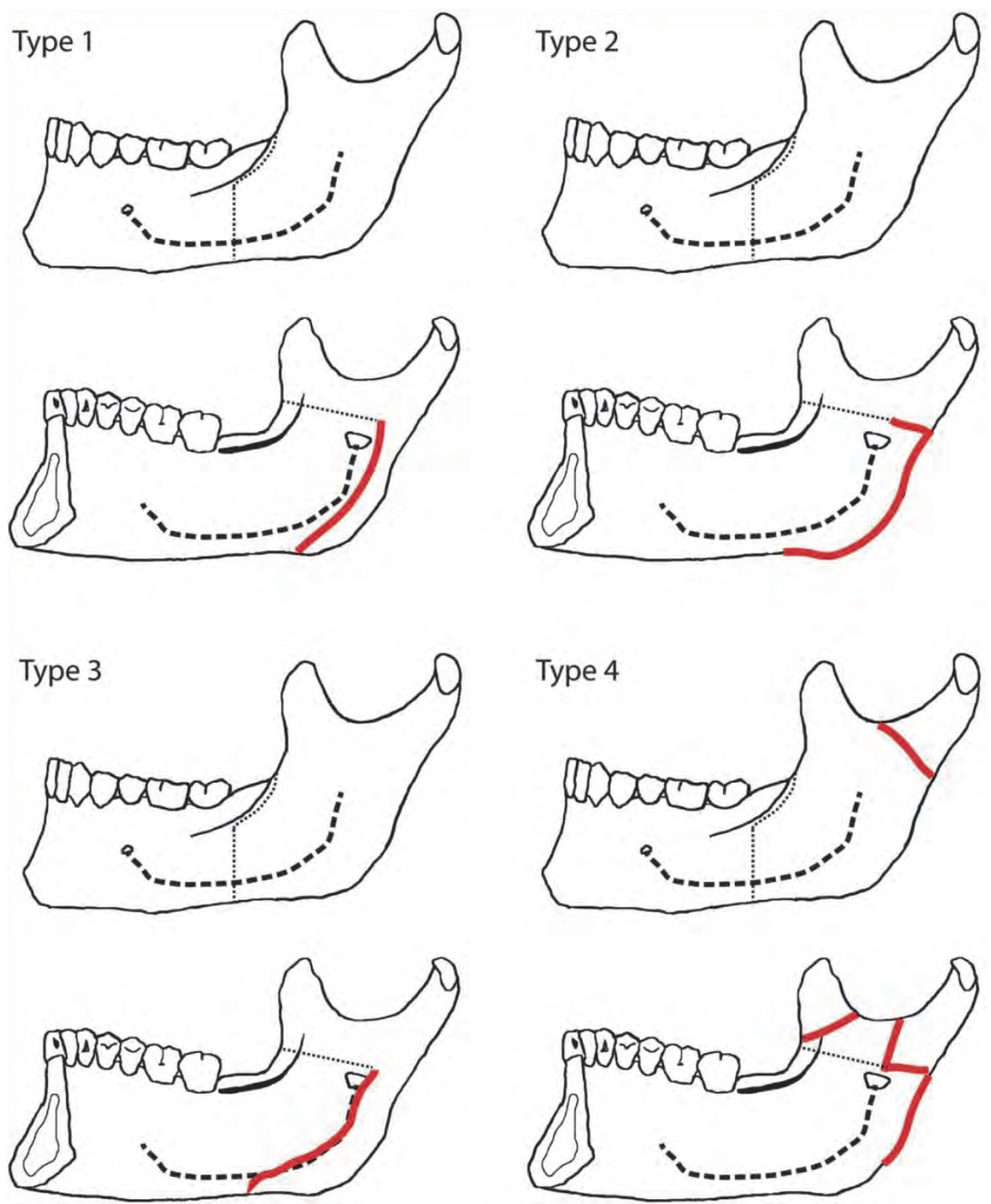

Figure 3. Classification of fracture patterns according to Plooij et al. ${ }^{11}$

\section{Statistical Analysis}

All data were analyzed using SPSS 20.0.0 (IBM Corp, Armonk, NY) on an Apple computer running OSX 10.9.0 (Apple Inc, Cupertino, CA). The Pearson $\chi^{2}$ test was used to compute the fracture patterns and the applied technique or the torque forces needed to split the 
mandibles. Paired $t$-test was used to compare the original with the modified splitting technique.

\section{RESULTS}

Seventy hemimandibles were split; 35 were split using the classic Obwegeser-Dal Pont technique, and 35 were split using a modified version of the Obwegeser-Dal Pont technique consisting of a fourth inferior border osteotomy.

The mean torque needed to split the hemimandible with the original technique was $1.38 \mathrm{Nm}$ (standard deviation, $0.60 \mathrm{Nm}$ ), whereas the average recorded torque required to split the hemimandible with the modified technique was $1.02 \mathrm{Nm}$ (standard deviation, $0.50 \mathrm{Nm}$ ). This difference was statistically significant according to paired $t$-test $(p<.001)$.

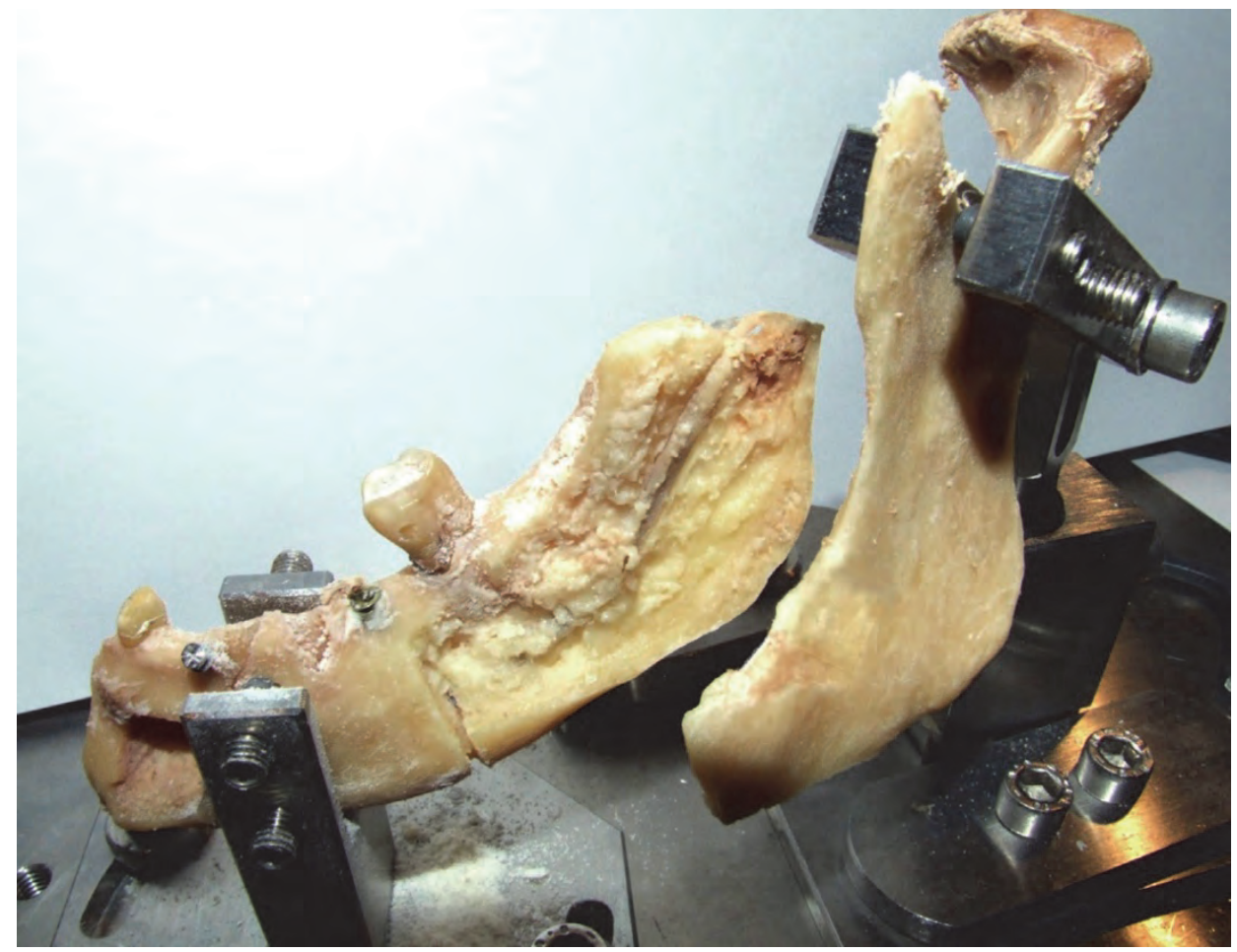

Figure 4. Type 2 splitting result with mandibular inferior border osteotomy.

The same trends were noted with the splitting patterns. Most hemimandibles split along the mandible canal (type 3 fracture) when using the Obwegeser- Dal Pont technique in combination with the authors' surgical protocol (Fig. 4). By adding the inferior 
border osteotomy, the hemimandibles fractured more often along the posterior border of the ramus (Table 1) through the mandibular angle (type 1 or 2 fracture; Fig. 5). Depending on the technique used, the splitting outcomes differed significantly from each other ( $p<.001$ by $\chi^{2}$ test).

A comparison of the force needed to split the mandible with the resulting fracture patterns showed no significant correlation for the entire group ( $p=.59$ by $\chi^{2}$ test) or for either technique (Obwegeser-Dal Pont technique, $p=.45$; modified technique, $p=.73$ ).

Table 1. Split-mouth model with 70 splits in 35 mandibles.

\begin{tabular}{llllll}
\hline & Type 1* & Type 2 & Type 3 & Type 4 & Total \\
\hline SSO & $6(8.6 \%)$ & $1(1.4 \%)$ & $26(37.1 \%)$ & $2(2.9 \%)$ & $35(50 \%)$ \\
SSO with inferior osteotomy & $15(21.4 \%)$ & $11(15.7 \%)$ & $9(12.9 \%)$ & 0 & $35(50 \%)$ \\
Total & $21(30 \%)$ & $12(17.1 \%)$ & $35(50 \%)$ & $2(2.9 \%)$ & $70(100 \%)$ \\
\hline
\end{tabular}

Note: Splitting results differ significantly depending on technique ( $p<.001$ by $\chi^{2}$ test).

Abbreviation: SSO, sagittal split osteotomy.

* Fracture types according to classification by Plooij et al. ${ }^{11}$

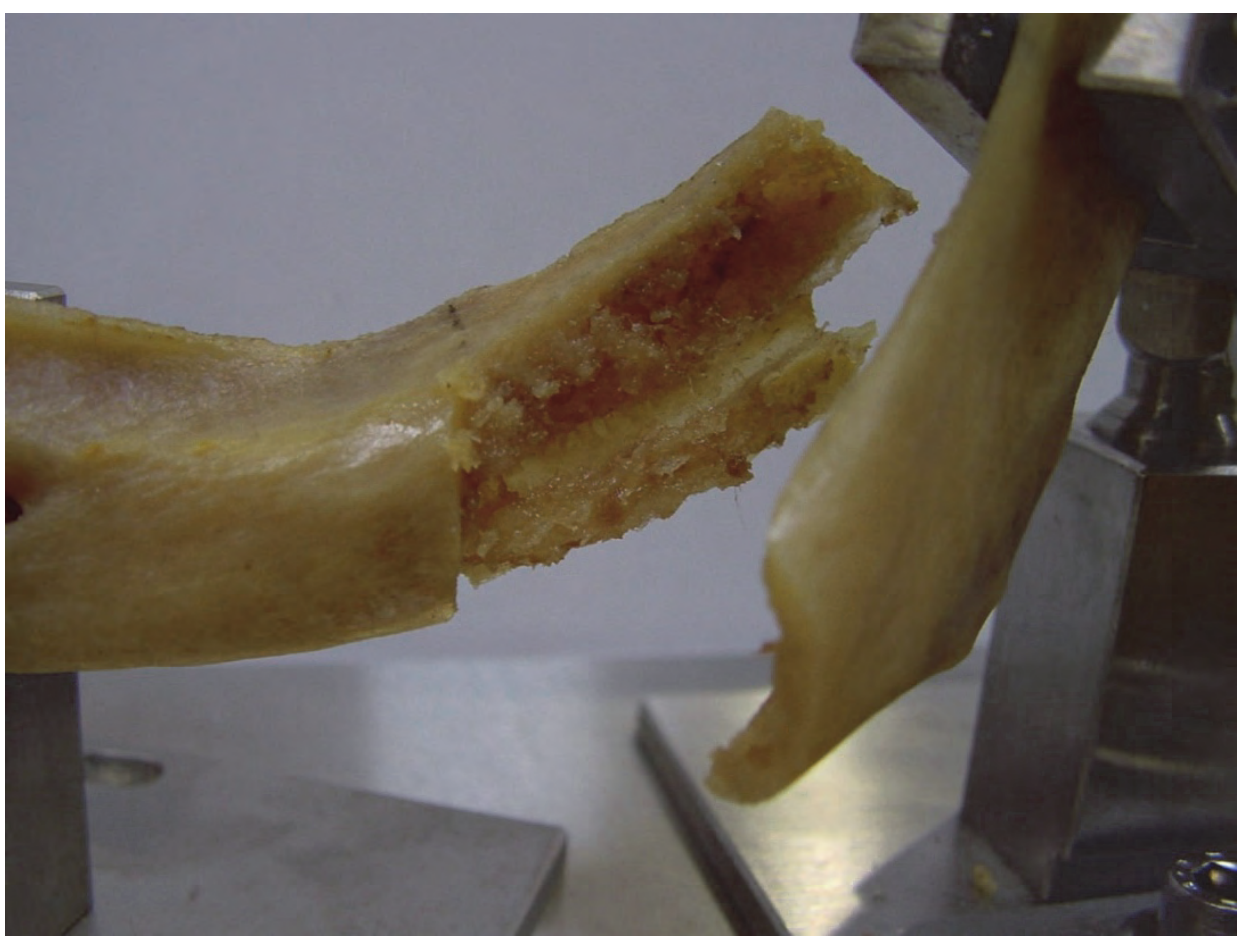

Figure 5. Type 3 splitting result without mandibular inferior border osteotomy. 


\section{DISCUSSION}

SSO is one of the most established techniques in orthognathic surgery. The fundamental technique has remained essentially unchanged, although numerous modifications have been made. Some modifications have been introduced to decrease the complications associated with this elective surgery, ${ }^{2-4,12,13}$ whereas others have been developed to achieve certain esthetic results. ${ }^{14}$

Damage to the $\mathrm{IAN}^{15}$ and unfavorable splits ${ }^{8}$ are the most common surgical complications, which are related to each other. In theory, the more any technique weakens the mandible in proportion to the depth of the osteotomy performed, the more it facilitates the splitting process. At most, it could mean adding osteotomies of the inferior and posterior borders to the classic Obwegeser procedure. These 2 regions are difficult to reach by an intraoral approach; however, the inferior border is much easier to access than the posterior border of the mandible.

To the authors' knowledge, there have been no studies addressing the biomechanics of SSO to optimize the technique or to prevent complications.

During the surgical splitting, there are 2 time points at which the IAN is at high risk, namely during manipulation of the medial side of the ramus ${ }^{16}$ and during fracturing, with the risk strongly correlated with the duration needed to perform the splitting. ${ }^{17}$ Several investigators have indicated that mechanical manipulation close to the IAN results in more postoperative sensitivity deficits. ${ }^{18-20}$

A split eased by a more weakened mandibular body could shorten the manipulation time on the lingual side, preventing chiseling around the IAN, because of the morepreformed splitting pattern, and it could decrease the operative time. These complications were addressed by the addition of an inferior border osteotomy. According to the authors' protocol, chiselling was stopped far above the alveolar canal. By doing so, good splitting results were achieved with the modified technique in the test setting. The present results showed that less torque force was needed to split the mandible with a more predictable splitting pattern. One must be careful when applying this modified technique during surgery, although the results reported by Wolford and Davis ${ }^{12}$ who achieved a predictable splitting result using an inferior border split in 150 patients, reinforce the present results to some extent. However, in the present study, several mandibles were partially or completely edentulous, which is not representative of most patients who often have complete dentition. In addition, all mandibles were fixed in formalin; therefore, their mechanical characteristics were somewhat changed, although the authors do not know the extent to which they were altered. Moreover, to date there is no instrument (eg, saw) that could be used to create an inferior border osteotomy by an intraoral approach in a safe and reproducible manner. Piezoelectric equipment $^{21}$ or a hooked oscillating saw (Fig. 6) might be used to create the inferior border osteotomy. With such an instrument at hand, a clinical trial might prove that the addi- 
tion of the mandibular border osteotomy to the SSO could improve this well- established technique.

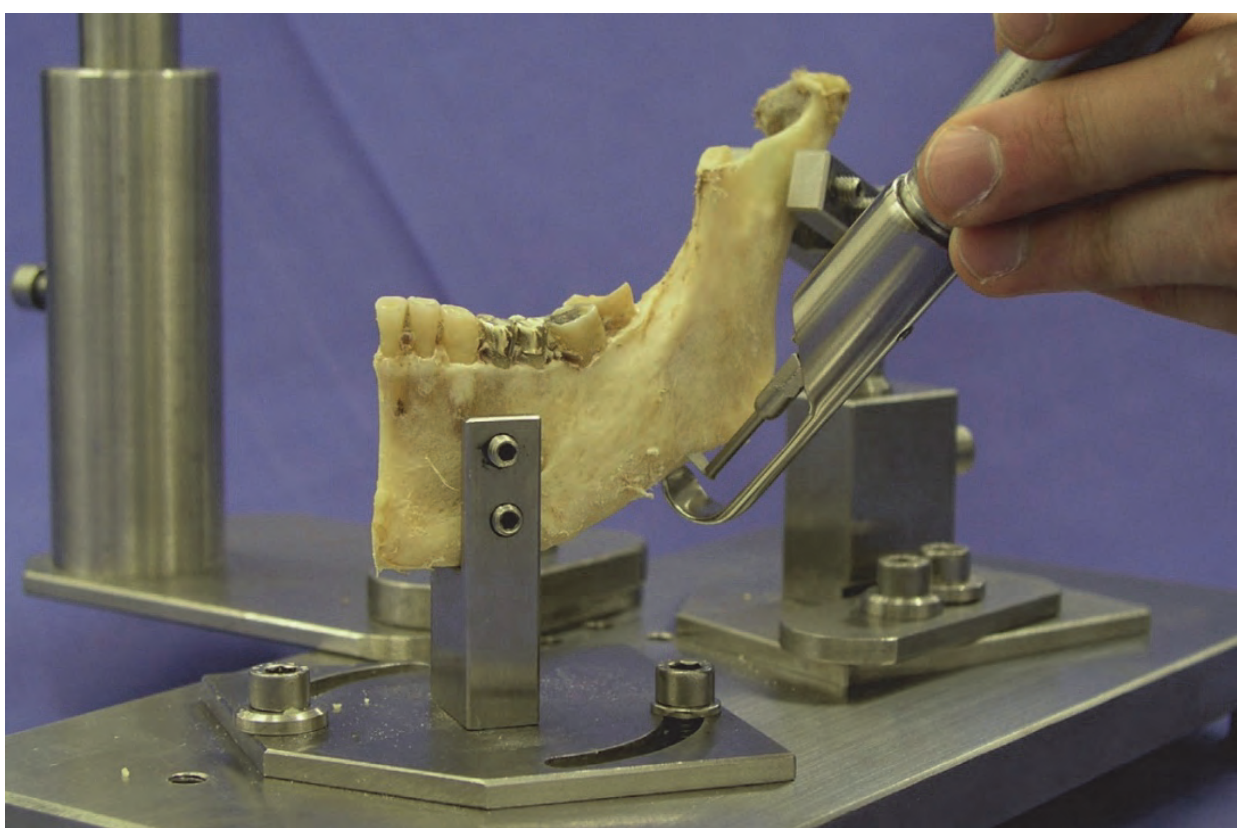

Figure 6. Prototype of a hooked oscillation saw with soft tissue protection.

\section{CONCLUSION}

The introduction of an additional osteotomy at the inferior border of the mandible considerably decreased the force that was needed to split the mandible in an in-vitro setting. Furthermore, it resulted in a more predictable splitting result. This modification of the SSO procedure may lead to less damage to the IAN by performing all these surgical manipulations at a safe distance from the nerve. 


\section{REFERENCES}

1. Trauner R, Obwegeser HL. Zur Operationstechnik bei der Progenie und anderen Unterkieferanomalien. Dtsch Zahn Mund Kieferheilkd. 1955;23:11-25.

2. Dal Pont G. Retromolar osteotomy for the correction of prognathism. J Oral Surg Anesth Hosp Dent Serv. 1961;19:42-47.

3. Hunsuck EE. A modified intraoral sagittal splitting technic for correction of mandibular prognathism. $J$ Oral Surg. 1968;26(4):250-253.

4. Epker BN. Modifications in the sagittal osteotomy of the mandible. J Oral Surg. 1977;35(2):157-159.

5. Wolford LM, Bennett MA, Rafferty CG. Modification of the mandibular ramus sagittal split osteotomy. Oral Surg Oral Med Oral Pathol. 1987;64(2):146-155.

6. Thygesen TH, Bardow A, Helleberg M, Norholt SE, Jensen J, Svensson P. Risk factors affecting somatosensory function after sagittal split osteotomy. J Oral Maxillofac Surg. 2008;66(3):469-474.

7. Colella G, Cannavale R, Vicidomini A, Lanza A. Neurosensory disturbance of the inferior alveolar nerve after bilateral sagittal split osteotomy: a systematic review. J Oral Maxillofac Surg. 2007;65(9):17071715.

8. Kriwalsky MS, Maurer P, Veras RB, Eckert AW, Schubert J. Risk factors for a bad split during sagittal split osteotomy. Br J Oral Maxillofac Surg. 2008;46(3):177-179.

9. Böckmann RA, Schön P, Frotscher M, Eggeler G, Lethaus B, Wolff K-D. Pilot study of modification of the bilateral sagittal split osteotomy (BSSO) in pig mandibles. J Craniomaxillofac Surg. 2011;39(3):169-172.

10. Kennedy E. Partial denture construction: a text book describing the technics of impression taking and the construction of that type of removable partial dentures which are supported and retained by external attachments. New York: N. Y., Dental items of interest publishing Company; 1928.

11. Plooij JM, Naphausen MTP, Maal TJJ, et al. 3D evaluation of the lingual fracture line after a bilateral sagittal split osteotomy of the mandible. Int J Oral Maxillofac Surg. 2009;38(12):1244-1249.

12. Wolford LM, Davis WM. The mandibular inferior border split: a modification in the sagittal split osteotomy. J Oral Maxillofac Surg. 1990;48(1):92-94.

13. Smith GI, Brennan PA, Oh SS, Markus AF. Modification of the Hunsuck sagittal split osteotomy using a nerve hook. Technical note. J Craniomaxillofac Surg. 2002;30(5):292-294.

14. Triaca A, Minoretti R, Saulacic N. Mandibula wing osteotomy for correction of the mandibular plane: a case report. Br J Oral Maxillofac Surg. 2010;48(3):182-184.

15. D'Agostino A, Trevisiol L, Gugole F, Bondí V, Nocini PF. Complications of orthognathic surgery: the inferior alveolar nerve. J Craniofac Surg. 2010;21(4):1189-1195.

16. Panula K, Neurosensory KO. Neurosensory deficits after bilateral sagittal split ramus osteotomy of the mandible - influence of soft tissue handling medial to the ascending ramus. Int J Oral Maxillofac Surg. 2004;33(6):543-548.

17. Teerijoki-Oksa T, Jääskeläinen SK, Forssell K, et al. Risk factors of nerve injury during mandibular sagittal split osteotomy. Int J Oral Maxillofac Surg. 2002;31(1):33-39.

18. Fridrich KL, Holton TJ, Pansegrau KJ, Buckley MJ. Neurosensory recovery following mandibular bilateral sagittal split osteotomy. J Oral Maxillofac Surg. 1995;53(11):1300-1306.

19. Nakagawa K, Ueki K, Takatsuka S, Yamamoto E. Trigeminal nerve hypesthesia after sagittal split osteotomy in setback cases: correlation of postoperative computed tomography and long-term trigeminal somatosensory evoked potentials. J Oral Maxillofac Surg. 2003;61:898-903.

20. Westermark $\mathrm{AH}$, Bystedt $\mathrm{H}$, Konow von L. Inferior alveolar nerve function after mandibular osteotomies. Br J Oral Maxillofac Surg. 1998;36(6):425-428.

21. Landes CA, Stübinger S, Rieger J, Williger B, Ha TKL, Sader R. Critical evaluation of piezoelectric osteotomy in orthognathic surgery: operative technique, blood loss, time requirement, nerve and vessel integrity. J Oral Maxillofac Surg. 2008;66(4):657-674. 



\section{Chapter}

\section{An in-vitro comparison study of the use of a drill or a saw in the Hunsuck-Dal Pont modification of the Obwegeser sagittal split osteotomy in pig mandibles}




\section{ABSTRACT}

Objective: Fracture lines in unfavorable locations are referred to as 'bad splits' in a mandibular sagittal split osteotomy (SSO). Several modifications of the technique by Obwegeser have been introduced to minimize this risk. This in-vitro study was performed to determine whether the shape of the osteotomy cut affects the torque and the fracture pattern of an SSO in pig mandibles.

Material and methods: In a split-mouth model, 16 mandibles were split according to the Hunsuck-Dal Pont modification of the Obwegeser technique. Using an oscillating saw, sharp-edged osteotomies were created on one side of the mandible and round-edged osteotomies were created on the contralateral side using a Lindemann burr. Torque forces were measured during the splitting, and the lingual fracture pattern of each split was classified.

Results: Torque forces were significantly ( $P<.05$ by paired $t$-test) decreased by $0.77 \mathrm{Nm}$ (15.6\%) when a saw was used for the osteotomy. In the 2 groups, fractures were produced along the mandibular canal. The mandible was more often completely fractured, including the lower mandibular border, when the fracture was created with an oscillating saw ( $P=.06$ by Pearson $\chi^{2}$ test). No correlation was found between the torque used and the fracture pattern.

Conclusion: Compared with round-edged osteotomies, sharp-edged osteotomies in pig mandibles facilitated the Hunsuck-Dal Pont modification of the Obwegeser sagittal splitting procedure and produced predictable results with decreased torque. 


\section{INTRODUCTION}

Many modifications of the sagittal split osteotomy (SSO) have occurred since its introduction by Trauner and Obwegeser ${ }^{1}$ in 1955. Each modification has addressed the localization of the osteotomy ${ }^{2-5}$ or the osteosynthesis. ${ }^{4,6,7}$ No previous studies have examined the influence of the chosen instrument on the splitting procedure.

In mechanical engineering, forces are commonly concentrated in 1 spot to maximize their effect or spread across the material to minimize their impact. These approaches are strongly related to design and construction. One example is the use of fillets in loadbearing mechanical parts. Fillets distribute the stress over a larger area, which minimizes the chance that the stress will exceed the maximum material strength and cause material failure (Fig. 1). Lindemann burs create U-shaped and thus filleted cuts (Fig. 2).

However, saw blades are very thin and form a pin-like, non-filleted, sharp-edged cut (Fig. 3). If mirrored to the SSO, then an osteotomy performed with a burr more closely resembles a filleted pole. An osteotomy performed with a saw is similar to a non-filleted pole and, in consequence, is more prone to failure, which is desirable during the splitting procedure (Fig. 4).

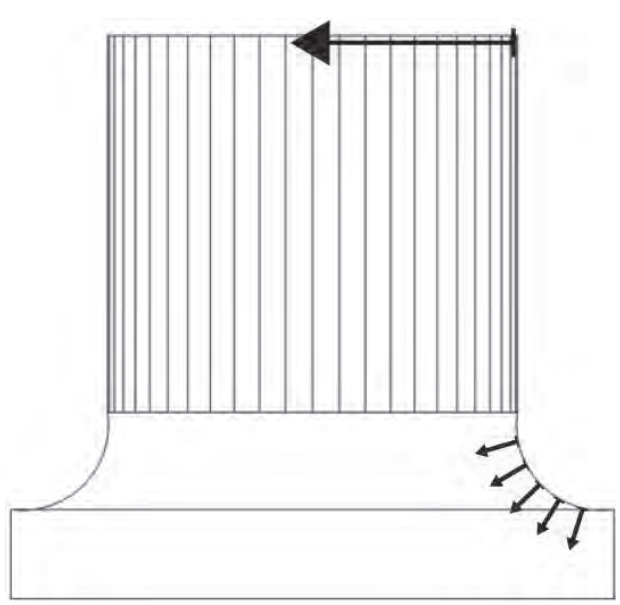

Figure 1. Forces are distributed over a wide area in a round-shaped cut. A large force is needed to exceed the maximum material strength and form a crack.

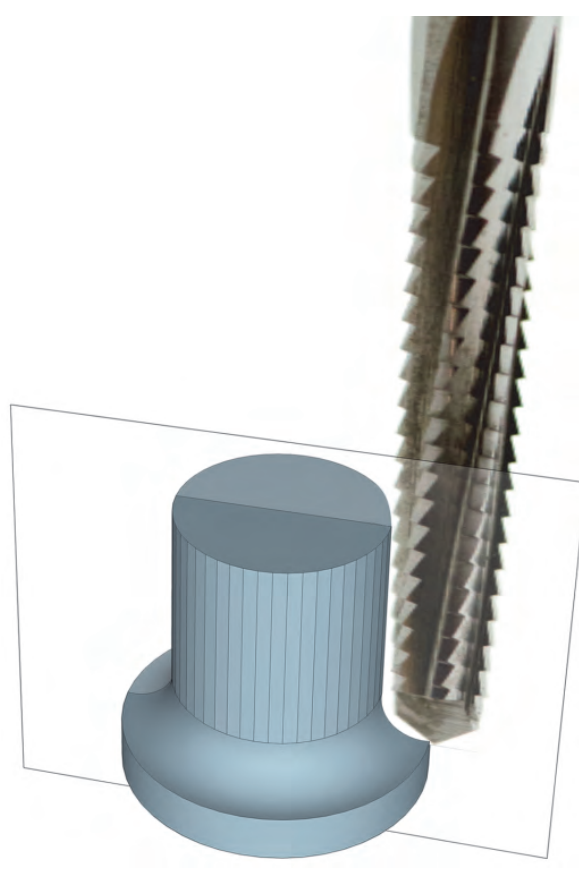

Figure 2. A Lindemann burr creates rounded cuts. 


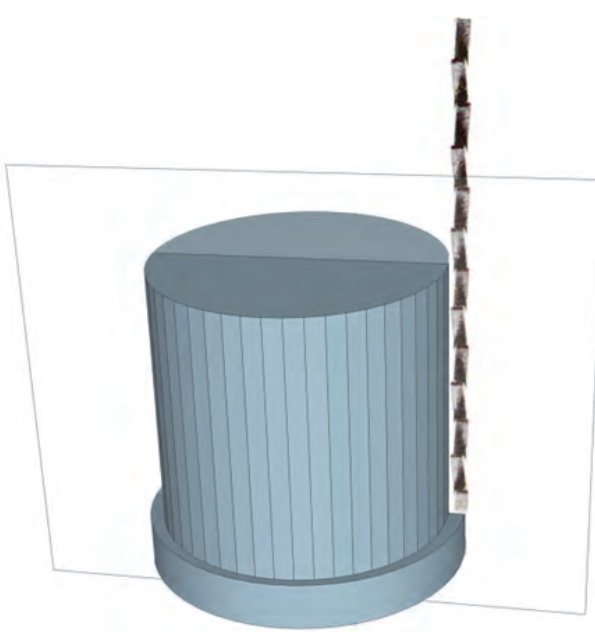

Figure 3. The edges of a cut produced by a saw are sharp.

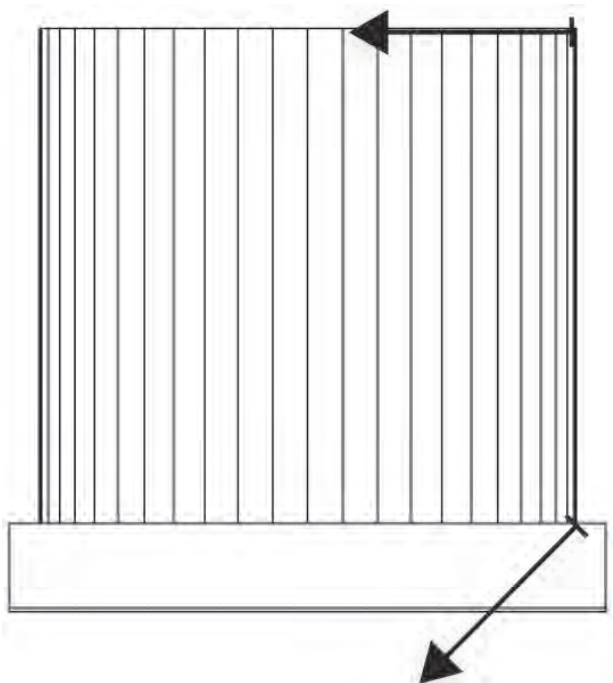

Figure 4. Applied stress is concentrated at the notch of the corner in a sharp-edged corner.

In this study, an in-vitro animal study of pig mandibles was used to examine the influence of the cutting instrument on the osteotomy technique described by Trauner and Obwegeser with the modifications of Hunsuck $^{3}$ and Dal Pont, ${ }^{2}$ which is performed using an oscillating saw to create a sharp-edged cut (Fig. 5) or a Lindemann burr to create a round-edged cut (Fig. 6).

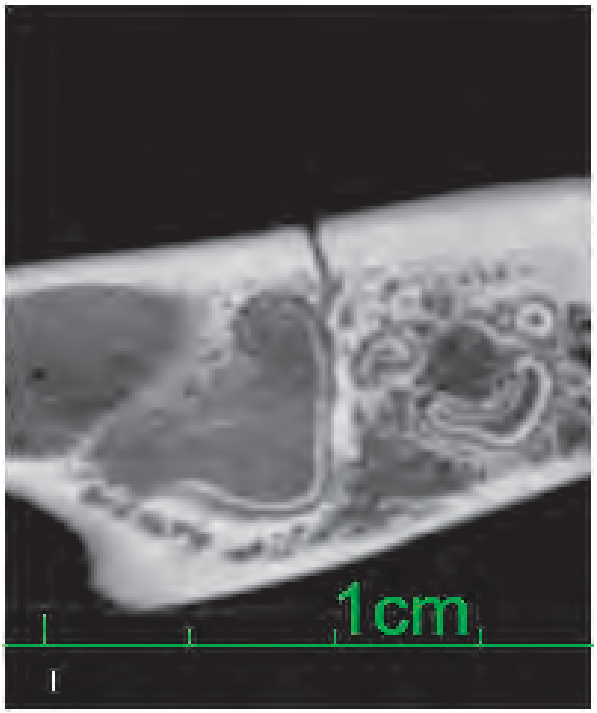

Figure 5. Vertical osteotomy of the buccal cortex with an oscillating saw.

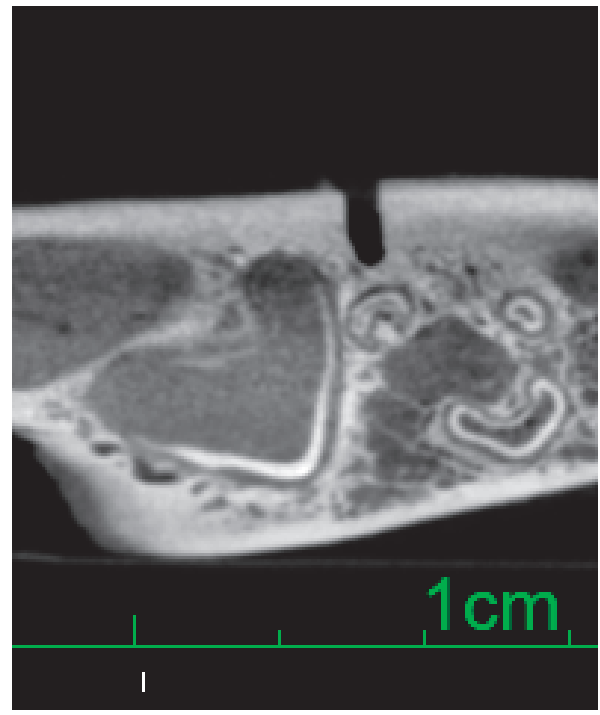

Figure 6. Vertical osteotomy of the buccal cortex with a Lindemann burr. 


\section{MATERIAL AND METHODS}

Sixteen pig mandibles where acquired from the local slaughterhouse. These pigs were a crossbreed between a Duroc pig and a Pietrain pig. All pigs had been slaughtered at 5 months of age and had an average mandible weight of $330 \mathrm{~g}$. The jaw was cut in half during standard processing in the slaughterhouse and kept paired to be used in a splitmouth model.

Each jaw half was mounted on the established test rack. ${ }^{8,9}$ The anterior part of the mandible was fixed, whereas the condylar part of the mandible was mobile in every dimension.

The sagittal split of the mandible was performed using a standardized procedure: the jaw was levelled along its occlusal plane and a perpendicular line was drawn through the most distal mental foramen (MEF) and the mandibular foramen (MAF). The distance between these 2 perpendicular lines was measured. The average distance between these 2 lines was $75 \mathrm{~mm}$. Using the perpendicular line through the MEF, the distance between the alveolar process and the MEF (PM) was measured and exhibited an average of $17 \mathrm{~mm}$ (Fig. 7).

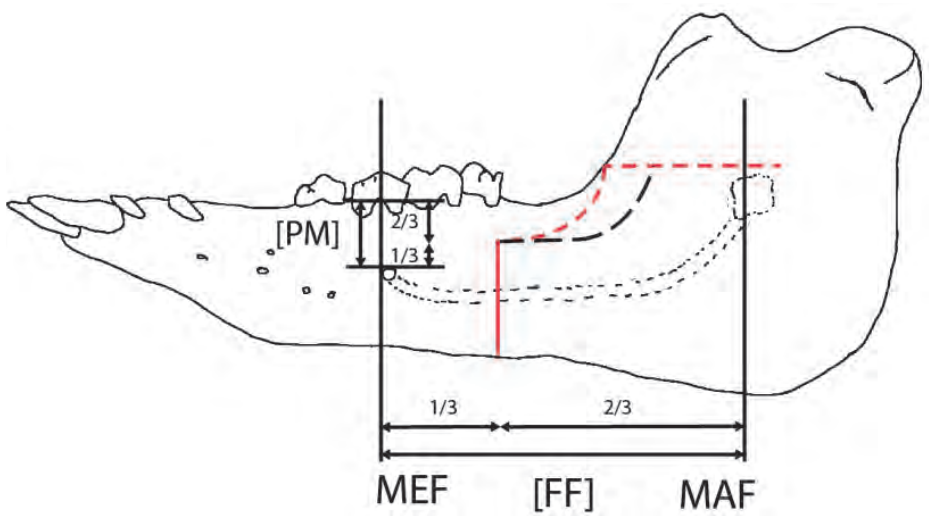

Figure 7. Applied measurements of the pig mandible. FF, distance between mental foramen and mandibular foramen; MAF, mandibular foramen; MEF, mental foramen; PM, distance from alveolar ridge to mental foramen.

The horizontal cut through the cortical layer was placed just above the MAF. Because the distal part of the ramus of the pigs was solid, the horizontal cut was stopped just after the foramen (Hunsuck modification). The vertical cut through the vestibular cortex was placed at two thirds of the FF along a perpendicular line through the submandibular notch in most cases. The 2 osteotomies were connected by a third osteotomy at two thirds of the PM distance deep through the cortex along the oblique line. A 16-mmwide osteotome was placed distal from the last molar tooth at $45^{\circ}$ to the base of the mandible, and it was inserted into the osteotomy until two thirds of the PM distance. 
For the splitting maneuver, the gauge was rotated clockwise for the right half of the mandible and counterclockwise for the left half of the mandible until the fracture was completed.

A Lindemann burr with a diameter of $1.5 \mathrm{~mm}$ was used to perform osteotomies on one side of the mandible (Fig. 8) and an oscillating saw with a blade thickness of 0.25 $\mathrm{mm}$ was used to make the cuts on the opposite side (Fig. 9). The instruments were randomly assigned to a side. A normal handpiece with a Meisinger 168RF was used as the Lindemann burr (Hager \& Meisinger $\mathrm{GmbH}$, Neuss, Germany), and a Medicon saw 68.24.12 with a 22-mm Medicon Instruments blade 68.24.15 was used as the oscillating saw (Medicon eG, Tuttlingen, Germany).

The osteotome was mounted to a torque gauge (HTG2-10, IMADA, Toyohashishi, Japan). The gauge was connected to a Windows XP-driven personal computer. ZLINK 2 2.02 International Edition software provided by IMADA was used for continuous data recording during the splitting procedure (Fig. 10). The fracture pattern on the lingual side was registered according to a modified classification by Plooij et al ${ }^{10}$ (Fig. 11). One subcategory was added to the original classification scheme; because class 3 represents a complete fracture along the mandibular canal, the added class $3 a$ represented an incomplete fracture along the mandibular canal with an intact inferior mandibular border.

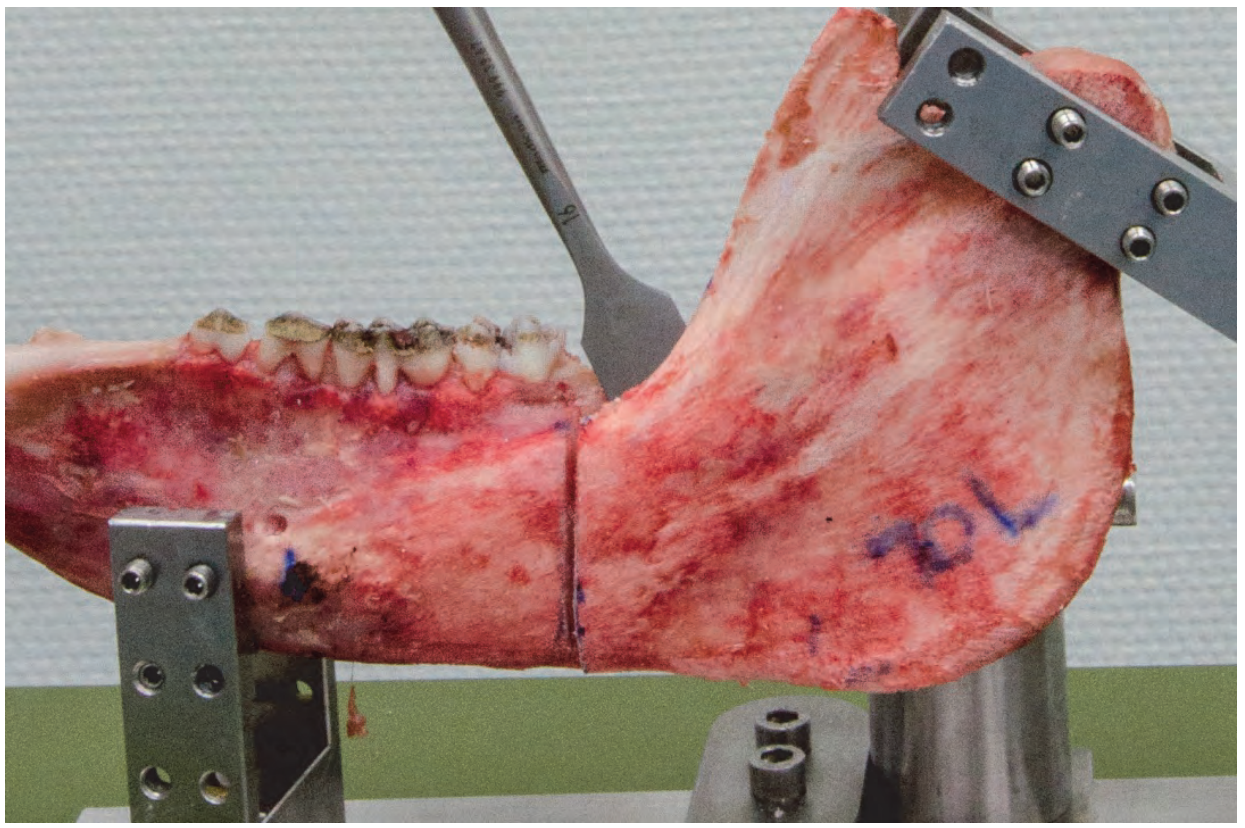

Figure 8. Osteotomy prepared with a Lindemann burr. 


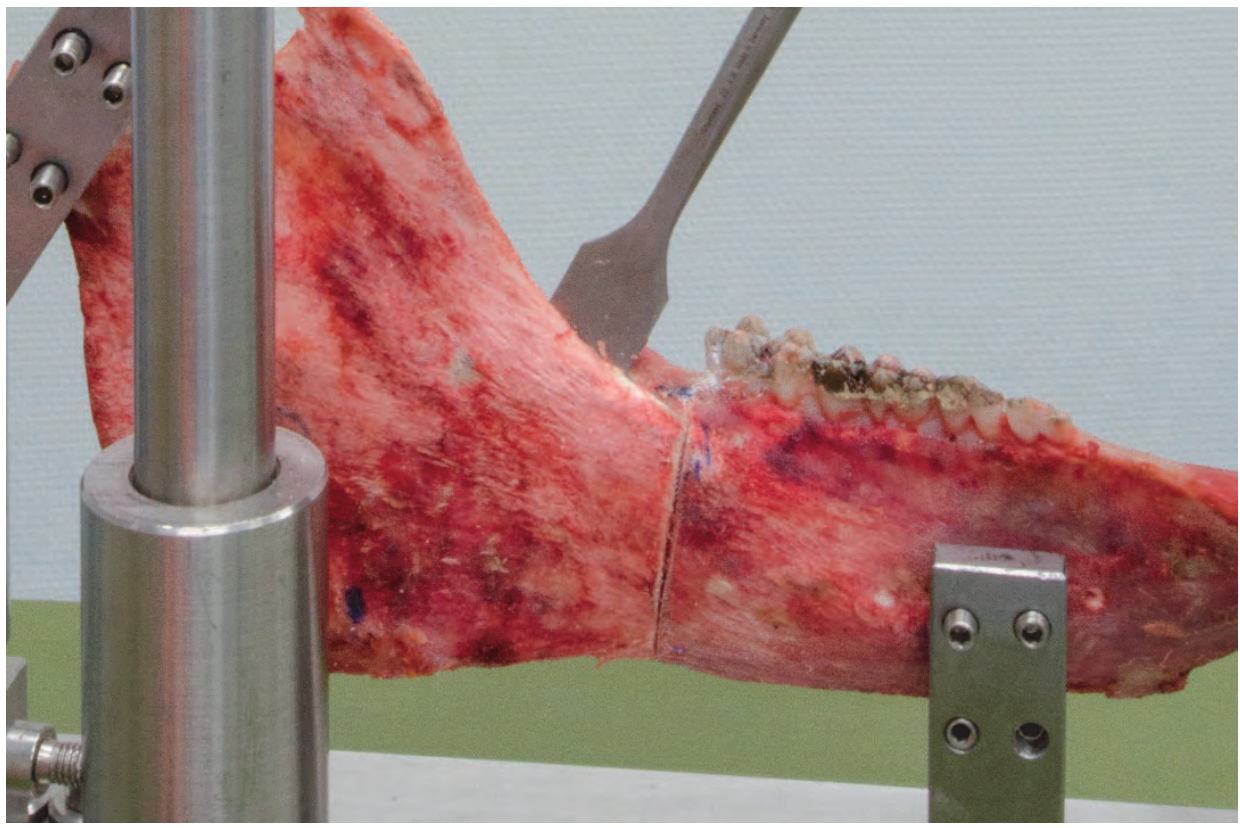

Figure 9. Osteotomy prepared with an oscillating saw.

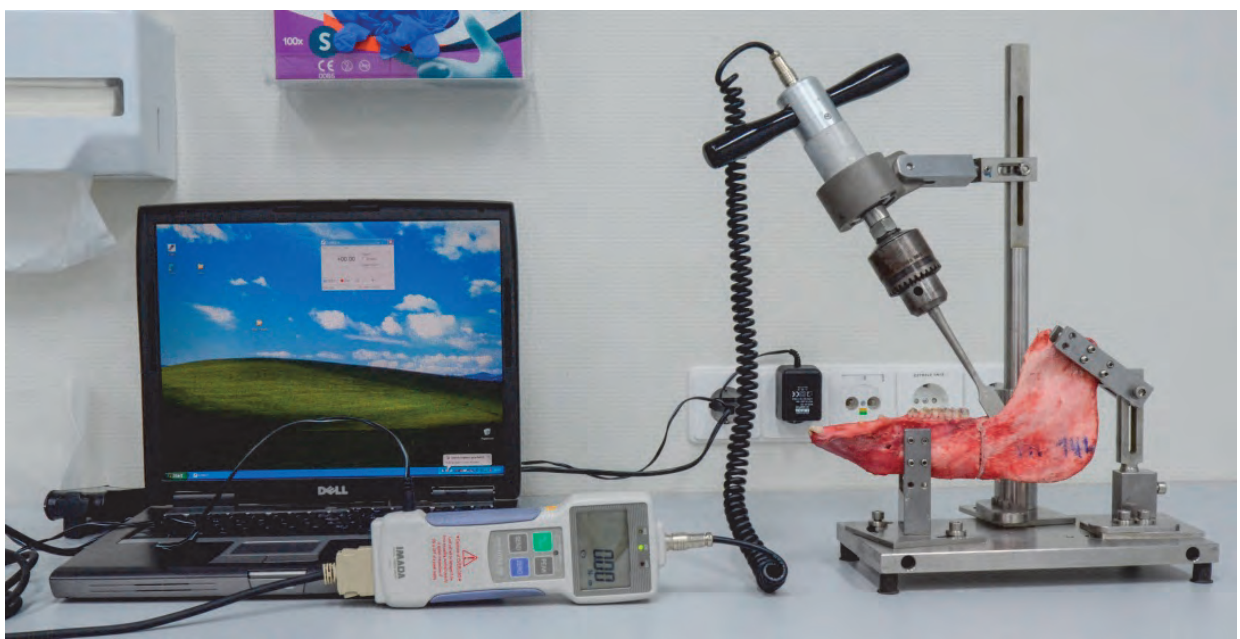

Figure 10: Experiment setup. A gauge with a chisel is connected to an analog-digital converter. Then, a converter is connected to a computer for continuous data recording.

The recorded data were exported into IBM SPSS Statistics 20 for the Macintosh computer (IBM Corp, Armonk, NY). A paired t-test was used to compare the torque forces for the split between the 'saw' side and the 'burr' side. Pearson $\chi^{2}$ test was used to determine whether a relevant difference was present in the fracture pattern after split- 
ting. The eta $(\eta)$ index was applied to determine whether any correlation existed between the force used to split the mandible and the resulting fracture patterns.
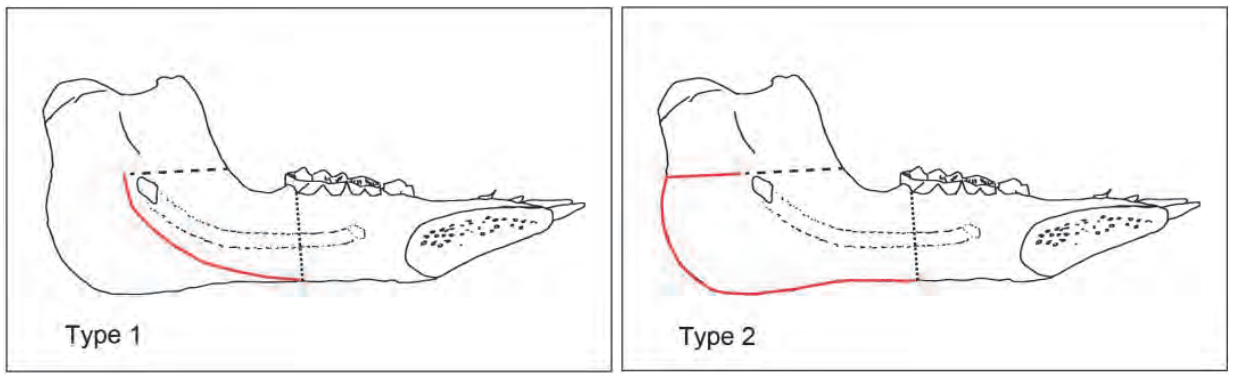

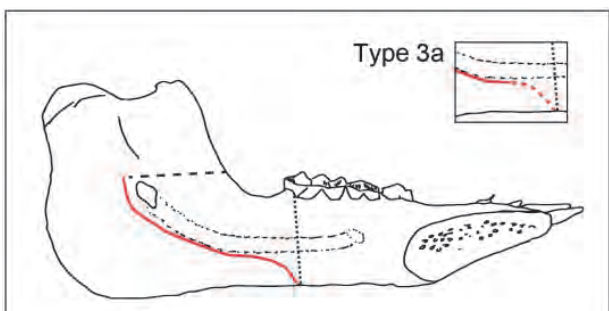

Type 3

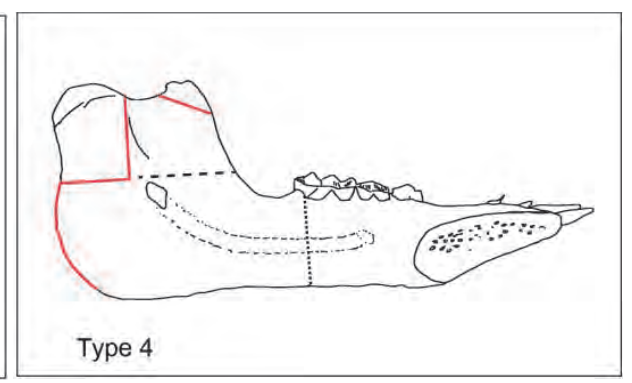

Figure 11: Lingual fracture types after mandibular sagittal splitting according to Plooij et al. ${ }^{10}$

\section{RESULTS}

The mandibles of all 16 pigs were cut in half through the median line and processed in pairs according to the split-mouth model. In half the pairs, a Lindemann burr was used to perform an osteotomy; in the other half, an oscillating saw was used.

In total, 32 pig hemimandibles were split sagittally according to the Hunsuck-Dal Pont modification of the Obwegeser technique. The average torque needed to split the pig mandibles with the oscillating saw was $4.17 \mathrm{Nm}$ (standard deviation [SD], 1.67 Nm). The average torque that was applied to split a pig mandible with a Lindemann burr was $4.94 \mathrm{Nm}$ (SD, $1.57 \mathrm{Nm}$ ). The torque that was necessary to sagittally split the mandible was significantly smaller for the side prepared using the saw than for the side prepared using the Lindemann burr (difference, $0.77 ; P<.05$ ).

Overall, $87.5 \%$ of the jaws prepared with the Lindemann burr showed a class 3 fracture pattern in contrast to $93.75 \%$ of the jaws prepared with the oscillating saw. More class 3a (incomplete) lingual fractures occurred when using a burr to accomplish the osteotomy lines; if an oscillating saw was used, then the fracture pattern was more likely a complete class 3 fracture. 
Two jaws prepared with the Lindemann burr were unfavorably fractured (class 4), and this did not occur in jaws treated with the oscillating saw (Table 1).

The fracture patterns differed according to the instrument used to prepare the osteotomy. The difference was almost significant $(P=.064)$. No correlation was found between the force used to split the mandible and the fracture pattern $(\eta=0.465)$.

Table 1. Distribution of fracture types depending on instrument used for an osteotomy.

\begin{tabular}{lllccl}
\hline Osteotomy & Type 1 & Type 2 & Type 3 & Type 3a & Type 4 \\
\hline Burr $(\mathrm{n}=16)$ & 0 & 0 & 6 & 8 & 2 \\
Saw $(\mathrm{n}=16)$ & 1 & 0 & 12 & 3 & 0 \\
Total $(\mathrm{n}=32)$ & 1 & 0 & 18 & 11 & 2 \\
\hline
\end{tabular}

\section{DISCUSSION}

Material sciences and mechanical engineering involve material and mechanical stability. Based on the application, forces are concentrated into 1 spot and used to alter the material in the most effective manner or forces are spread over a large area to prevent material transformation, which causes failure in most cases.

The mandible fracture by an SSO, which is a failure in mechanical engineering terms, should be accomplished by the weakest possible forces or by the least possible manipulation. Even if an SSO is not optimally prepared, the applied forces should be concentrated at the osteotomy lines and at the inferior border of the mandible to deliver a favorable split. This raises the question of how to guide the applied forces onto the projected fracture lines in the most effective and safest manner.

Since the introduction of the SSO more than 50 years ago, a constant stream of publications has described modifications of the original technique. In the first article introducing the SSO, Trauner and Obwegeser ${ }^{1}$ advised using a saw or Lindemann burr for a vertical osteotomy, a saw for a horizontal osteotomy, and a burr to connect these 2 lines. Dal Pont ${ }^{2}$ performed all osteotomies with only a Lindemann burr. Several years later, when describing the first modification of his technique, Obwegeser ${ }^{11}$ still used the Lindemann burr for a horizontal osteotomy but made no comment about the vertical or connecting osteotomy. According to the included photographs, it is likely that he used a Lindemann burr for these cuts. Neither Hunsuck ${ }^{3}$ nor Epker ${ }^{4}$ published the type of instruments they had used in their studies. In a stepwise explanation of his inferior border technique, Wolford ${ }^{12}$ used Lindemann and fissure burs to prepare horizontal and vertical osteotomies, respectively.

Currently, the standard method of calculating forces inside a material is the finite element method (FEM). The variation in size, composition, and components hampers the use of this model in human or animal mandibles. Some mandibles consist of more cancellous bone, whereas some have a thicker cortical bony layer. The SSO partly involves 
the sandwich construction of the jaw (mandibular body) and partly involves homogenous cortical bone (mandibular angle, parts of the ramus). The standard assumptions of strength of the cancellous layer vary from $0.21^{13}$ to $3.8 \mathrm{GPa}$ and can range up to 14.8 $\mathrm{GPa}^{14}$ for the Young tissue modulus, which is an important parameter in the FEM.

These findings become even more complex if other factors such as the impurity of the material (the mandible) are considered. The mandibular canal, an impacted or retained tooth, and the roots of normally erupted teeth can be regarded as 'impurities' that can influence the distribution of applied stress within the jaw.

A long discussion has been ongoing on whether an impacted third molar increases the risk of an unfavorable split. In material science, one would consider such a tooth an impurity of the material, and thus the material would be more prone to material weakness. For example, in traumatology, the fracture line very often crosses through the cavity of the third molar. In orthognathic surgery, some investigators have reported a higher incidence of unfavorable splits with persistent third molars, ${ }^{15,16}$ whereas others have denied any influence ${ }^{17,18}$; some have related the risk of a persistent third molar to the patient's age. ${ }^{19}$ These different results might be explained by the slightly different techniques used (eg, deep vs superficial chiseling or the position of the vertical osteotomy), which alter the distribution of the applied forces within the mandible.

All these uncertainties make it difficult to establish a predictable working FEM apart from anatomic variations. ${ }^{20}$ For this reason, a split-mouth model in an animal cadaver study seems to be more reliable model than FEM.

How substantial is the influence of the instrument used for the preparation compared with the other factors from a mechanical perspective?

Using a conventional experiment, the authors found that the torque force was markedly decreased by $15.6 \%$ when a saw was used for the Hunsuck-Dal Pont modification of the Obwegeser osteotomy compared with an osteotomy conducted with a Lindemann drill. The need to use less force to break material fits well with the mechanical knowledge ${ }^{20}$ that stress is more concentrated in cracks with a smaller diameter. The authors also observed this phenomenon by adding an osteotomy at the caudal rim of the mandible, which guides the splitting force to the planned crack and decreases the force by $29 \% .^{8}$

The mandible body transforms in a linear elastic manner under a force of up to 150 $\mathrm{N}^{21,22}$ The present results are consistent with these findings, because torque forces of up to $8.5 \mathrm{Nm}$ were applied. The torque diagram showed a linear increase until the forces decreased in a stepwise manner (Fig. 12). Fracturing of the vertical and horizontal osteotomy and eventually of the caudal border of the mandible can be retraced in the diagram. The authors found a large percentage (56\%) of type 3 (3a) fractures compared with the study by Plooij et al, ${ }^{10}$ which reported a rate of $32.5 \%$ in human mandibles. The mandibular angle is very solid in pigs. It consists of only cortical bone, and it covers a larger area than the human mandibular angle. The stress concentration is highest in the mandibular canal as the first exposed line of minor resistance. The same explanation is 
effective for the absence of type 2 fractures. Use of a saw for an osteotomy results in more complete fractures of the vertical osteotomy (type 3 vs incomplete type 3a fractures). One of the most common fracture patterns in 'bad splits' is a fracture of the buccal plate at an unfavorable location. ${ }^{23}$ Using an oscillating saw, a well-defined crack is created in an otherwise thin lamella, ${ }^{24}$ forcing the stress to be focused at the future fracture line.

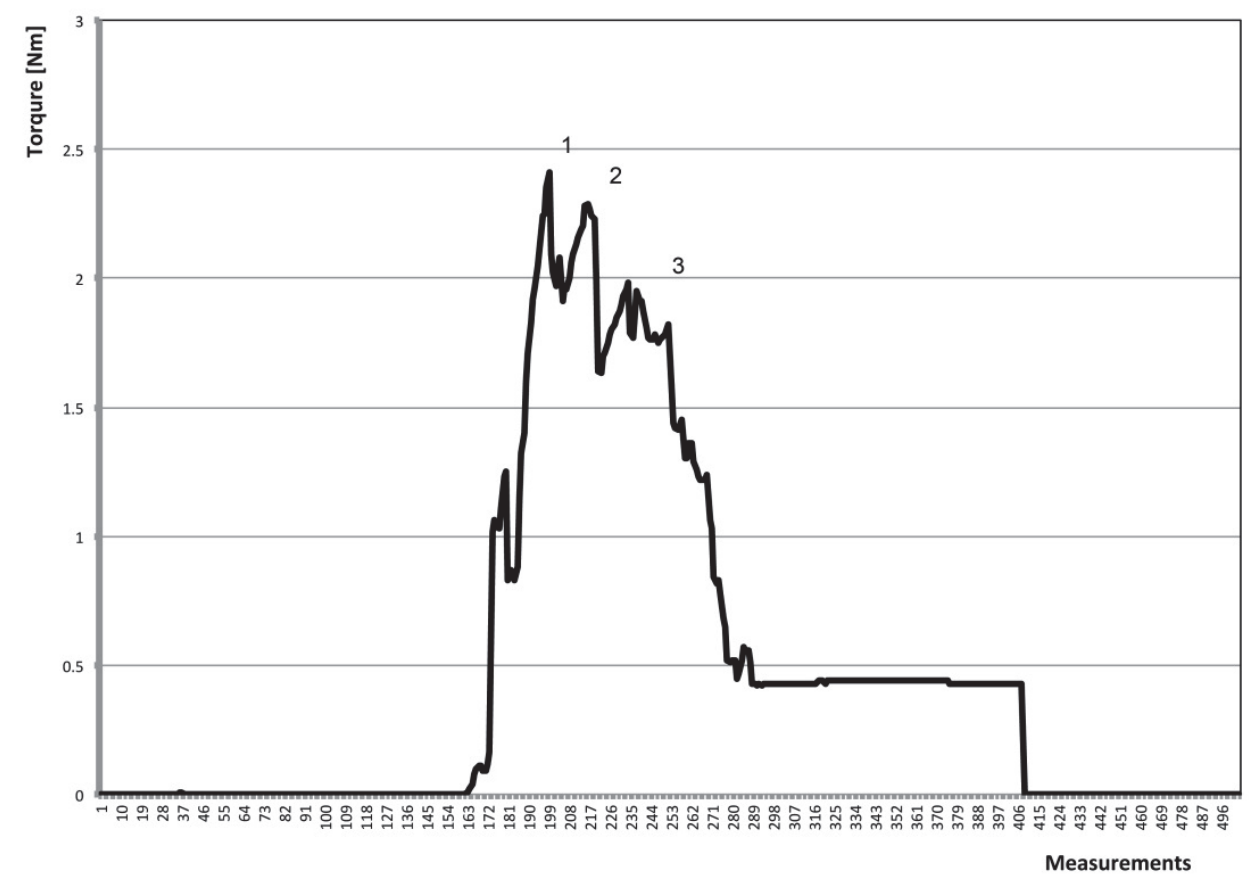

Figure 12: Torque recording of sagittal splitting. 1,Fracture of the buccal osteotomy; 2, fracture of the horizontal osteotomy; 3 ,fracture of the inferior mandibular border.

This experiment also showed that the combination of a well-performed osteotomy and the use of only 1 chisel is not sufficient to create a type 1 or 2 split in pig mandibles. This finding is consistent with the study by Schön et al. ${ }^{25}$ Using 1 chisel, they found that $100 \%$ of all sagittal splits in pig mandibles occurred through the mandibular canal.

\section{CONCLUSION}

In-vitro experiments using the Hunsuck-Dal Pont modification of the Obwegeser SSO procedure in pig mandibles showed that stress applied by a torquing instrument is more effectively concentrated into the sharp-edged osteotomy lines created using an oscillating saw than into round-shaped osteotomy lines created using a Lindemann burr. There 
is some evidence that use of a saw for an osteotomy produces a more predictable buccal fracture in pig mandibles.

In transferring these results to the human mandible, the authors expect even more important results because of the presence of less cortical bone in the angular area than in pig mandibles. The choice of the instrument that is used to perform an osteotomy in humans might be an important factor in the resulting splitting pattern; other factors include the splitting technique, the anatomy of the mandible, and the lack of persistence of the third molars. 


\section{REFERENCES}

1. Trauner R, Obwegeser HL. Zur Operationstechnik bei der Progenie und anderen Unterkieferanomalien. Dtsch Zahn Mund Kieferheilkd. 1955;23:11-25.

2. Dal Pont G. Retromolar osteotomy for the correction of prognathism. J Oral Surg Anesth Hosp Dent Serv. 1961;19:42-47.

3. Hunsuck EE. A modified intraoral sagittal splitting technic for correction of mandibular prognathism. $J$ Oral Surg. 1968;26(4):250-253.

4. Epker BN. Modifications in the sagittal osteotomy of the mandible. J Oral Surg. 1977;35(2):157-159.

5. Wolford LM, Davis WM. The mandibular inferior border split: a modification in the sagittal split osteotomy. J Oral Maxillofac Surg. 1990;48(1):92-94.

6. Spiessl B. Rigid internal fixation after sagittal split osteotomy of the ascending ramus. In: Spiessl B, ed. New concepts in maxillofacial bone surgery. Berlin, Heidelberg: Springer; 1976:115-122.

7. Paulus GW, Steinhäuser EW. A comparative study of wire osteosynthesis versus bone screws in the treatment of mandibular prognathism. Oral Surg Oral Med Oral Pathol. 1982;54(1):2-6.

8. Böckmann RA, Schön P, Frotscher M, Eggeler G, Lethaus B, Wolff K-D. Pilot study of modification of the bilateral sagittal split osteotomy (BSSO) in pig mandibles. J Craniomaxillofac Surg. 2011;39(3):169-172.

9. Böckmann RA, Schön P, Neuking K, Meyns J, Kessler PAWH, Eggeler G. In vitro comparison of the sagittal split osteotomy with and without inferior border osteotomy. J Oral Maxillofac Surg. 2015;73(2):316-323.

10. Plooij JM, Naphausen MTP, Maal TJJ, et al. 3D evaluation of the lingual fracture line after a bilateral sagittal split osteotomy of the mandible. Int J Oral Maxillofac Surg. 2009;38(12):1244-1249.

11. Obwegeser HL. The indications for surgical correction of mandibular deformity by the sagittal splitting technique. Br J Oral Surg. April 1964:157-171.

12. Wolford LM. Influence of osteotomy design on bilateral mandibular ramus sagittal split osteotomy. J Oral Maxillofac Surg. 2015;73(10):1994-2004.

13. Maurer P, Holweg S, Schubert J. Finite-element-analysis of different screw-diameters in the sagittal split osteotomy of the mandible. J Craniomaxillofac Surg. 1999;27(6):365-372.

14. van Rietbergen $B$, Weinans $H$, Huiskes $R$, Odgaard A. A new method to determine trabecular bone elastic properties and loading using micromechanical finite-element models. J Biomech. 1995;28(1):69-81.

15. Verweij JP, Mensink G, Fiocco M, van Merkesteyn RJPR. Presence of mandibular third molars during bilateral sagittal split osteotomy increases the possibility of bad split but not the risk of other postoperative complications. J Craniomaxillofac Surg. 2014;42(7):E359-E363.

16. Reyneke JP, Tsakiris $P$, Becker P. Age as a factor in the complication rate after removal of unerupted/impacted third molars at the time of mandibular sagittal split osteotomy. J Oral Maxillofac Surg. 2002;60(6):654-659.

17. Kriwalsky MS, Maurer P, Veras RB, Eckert AW, Schubert J. Risk factors for a bad split during sagittal split osteotomy. Br J Oral Maxillofac Surg. 2008;46(3):177-179.

18. Doucet J-C, Morrison AD, Davis BR, Gregoire CE, Goodday R, Precious DS. The presence of mandibular third molars during sagittal split osteotomies does not increase the risk of complications. J Oral Maxillofac Surg. 2012;70(8):1935-1943.

19. Chrcanovic BR, Freire-Maia B. Risk factors and prevention of bad splits during sagittal split osteotomy. Oral Maxillofac Surg. 2012;16(1):19-27.

20. Inglis CE. Stresses in plates due to the presence of cracks and sharp corners. Transactions of the Institute of Naval Architects. 1913;55:219-241.

21. Vollmer D, Meyer U, Joos U, Vègh A, Piffkò J. Experimental and finite element study of a human mandible. J Craniomaxillofac Surg. 2000;28(2):91-96.

22. Erkmen E, Simsek B, Yucel E, Kurt A. Three-dimensional finite element analysis used to compare methods of fixation after sagittal split ramus osteotomy: setback surgery-posterior loading. Br J Oral Maxillofac surg. 2005;43(2):97-104. 


\section{Chapter 6}

23. Steenen SA, Becking AG. Bad splits in bilateral sagittal split osteotomy: systematic review of fracture patterns. Int J Oral Maxillofac Surg. 2016;45(7):887-897.

24. Aarabi M, Tabrizi R, Hekmat M, Shahidi S, Puzesh A. Relationship between mandibular anatomy and the occurrence of a bad split upon sagittal split osteotomy. J Oral Maxillofac Surg. 2014;72(12):2508-2513.

25. Schön P, Frotscher M, Eggeler G, Kessler PAWH, Wolff K-D, Böckmann RA. Modification of the bilateral sagittal split osteotomy (BSSO) in a study using pig mandibles. Int J Oral Maxillofac Surg. 2011;40(5):516520. 


\section{Chapter}

\section{Lingual fracture patterns of the mandible split in humans using the inferior border osteotomy - preliminary results}

R. Böckmann, N. Lie, J. Meyns, P.A.W.H. Kessler

Submitted to Journal of Cranio-Maxillo-Facial Surgery 


\section{ABSTRACT}

Objective: In-vitro studies showed more consistent splitting results and a smoother splitting procedure if an inferior border osteotomy had been added to the mandibular sagittal split osteotomy by Obwegeser-Dal Pont.

Material and methods: Preliminary results are presented from three patients from a randomized controlled prospective study. In a split-mouth model, one side of the mandible was split in the traditional way. An inferior border osteotomy was added on the contralateral side.

Results: Creating the inferior border osteotomy with a rotating shielded saw proved to be safe without serious damage to the surrounding perimandibular tissue. Torque forces to complete the split were smaller with the modified technique compared to the original method. The lingual fracture line in the modified technique resembled more the classical Obwegeser-Dal Pont fracture than the ones with the original technique, which were likely to run along the mandibular canal.

Conclusion: These results encouraged us to proceed with this study. 


\section{INTRODUCTION}

Many modifications of the original sagittal split osteotomy have been introduced to facilitate the procedure and to minimize its complications since its introduction by Hugo Obwegeser in $1954 .^{1-5}$ Despite all these efforts, complications as damage to the inferior alveolar nerve or the unfavorable split ("bad split") are common and they are still the subject of recent publications. ${ }^{6-12}$ Wolford was the first to alter the technique significantly by adding an inferior border osteotomy to the initial vertical, horizontal and crestal osteotomies. In-vitro studies proved its effectiveness in reducing the applied torque by $26 \%$. At the same time, its lingual fracture line is more likely to run through the posterior border of the mandible, ${ }^{13,14}$ as postulated by Obwegeser. In this article, we report about the first results of this comparison in a randomized prospective study in humans. In a split-mouth model, one side of the mandible was split using the technique of Obwegeser-Dal Pont and the contralateral side was split with the same technique and the additional inferior border osteotomy. The torque to complete the splitting was measured and the lingual fracture lines were categorized postoperatively.

\section{MATERIAL AND METHODS}

A prospective randomized controlled clinical study in humans was set up to compare the sagittal split osteotomy with or without inferior border osteotomy in a split-mouth model. The comparison included the torque that was applied to split the mandible and the pattern of the lingual fracture line in order to evaluate the quality of the splitting result. After obtaining a written informed consent, only healthy patients who needed a BSSO operation enrolled in the study. Patients who underwent revision surgery or patients with syndromes were excluded.

The procedure took place under general anesthesia. It consisted of a sagittal split osteotomy of the mandible according to Obwegeser-Dal Pont on the one side and of a sagittal split osteotomy with a well-defined inferior border osteotomy on the other side. A KaVo rotating saw type 2444 with a shielded $8 \mathrm{~mm}$ diameter blade was used for the inferior border osteotomy (Fig. 1). A $12 \mathrm{~mm}$ width osteotome that was used for the final spitting had been attached to an HTG2-10 gauge developed by IMADA (Toyohashishi, Japan). The applied forces were constantly measured with a frequency of 33 times per second and an accuracy of $0.5 \%$. All acquired data was recorded using ZLINK software version 2.02E provided by IMADA on a personal computer.

A cone beam computed tomography $(\mathrm{CBCT})$ with a resolution of 0.4 voxels was made at the first post-operative day to categorize the lingual fracture lines of both sides according to Plooij ${ }^{15}$. The Maastricht University Ethic Commission approved this study under NL54299.068.15/METC152047. 


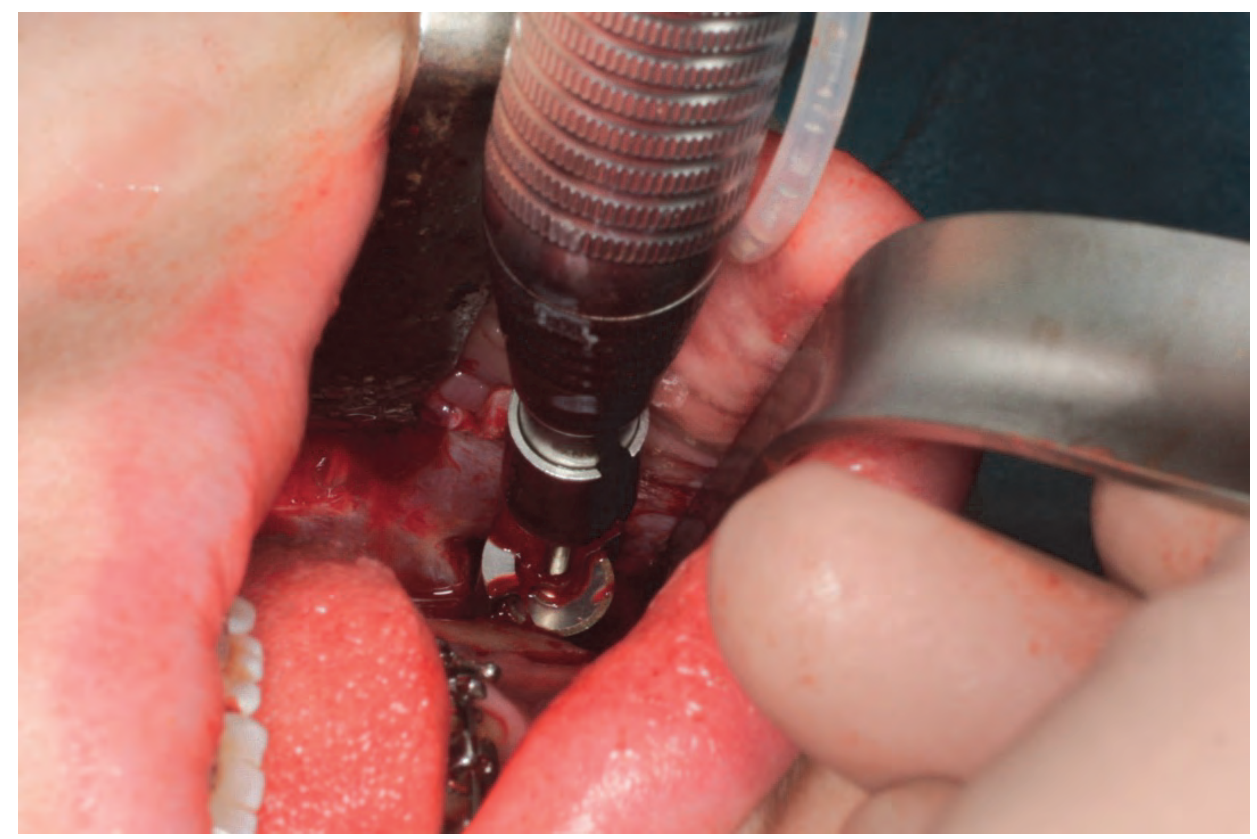

Figure 1. The saw positioned at the lower border of the mandible ready for the inferior border osteotomy

\section{RESULTS}

So far three patients have been operated on. Table 1 shows the classification of the lingual fracture lines and the maximum applied torque during the splitting procedure. All lines deriving from the modified technique resembled more an Obwegeser-Dal Pont split (class I or II). To the contrary, the lingual split of the traditional technique is more likely to run along the mandibular canal (class III, Fig. 2). Less torque was used in all modified splittings compared to the traditional technique.

Table 1. Lingual fracture pattern classified according to Plooij and the maximum torque used to split the mandible.

\begin{tabular}{llll}
\hline $\begin{array}{l}\text { Lingual fracture pattern/ } \\
\text { max. torque }[\mathrm{Nm}]\end{array}$ & Pat 1 & Pat 2 & Pat 3 \\
\hline Modified & $1(2.1 \mathrm{Nm})$ & $1(1.57 \mathrm{Nm})$ & $2(0.88 \mathrm{Nm})$ \\
Traditional & $3(2.38 \mathrm{Nm})$ & $3(1.67 \mathrm{Nm})$ & $3(1.15 \mathrm{Nm})$ \\
Difference (torque) & $0.28 \mathrm{Nm}(11.8 \%)$ & $0.11 \mathrm{Nm}(6.0 \%)$ & $0.27 \mathrm{Nm}(23.5 \%)$ \\
\hline
\end{tabular}



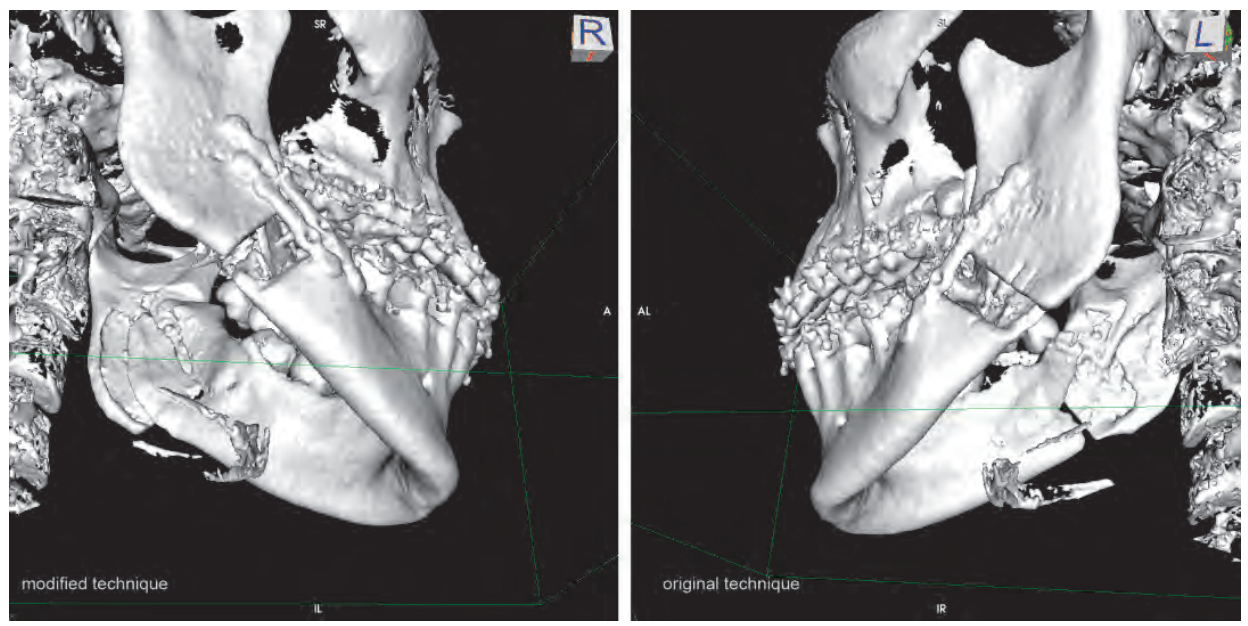

Figure 2. Postoperative lingual split pattern. Left: Result with inferior border osteotomy. Right: Result without inferior border osteotomy.

\section{DISCUSSION}

Since its introduction in 1954, the sagittal split osteotomy by Obwegeser defines the golden standard in orthognathic surgery of the mandible.

As stated by Obwegeser himself ${ }^{16}$ and in spite of its elegant design, the sagittal split is associated with complications. Dal-Pont relocated the proximal osteotomy from the mandibular angle to the beginning of the oblique line after the second molar to facilitate a mandible set-back and to prevent a non-union of the fragments. ${ }^{17}$ By shortening the horizontal osteotomy, Hunsuck shifted the posterior and blind fracture line away from the posterior border of the ascending ramus towards or through the mandibular canal. $^{2}$ This procedure decreases the mucoperiosteal deflection and thus trauma to the neurovascular bundle. Reflecting the neurovascular bundle during the horizontal osteotomy has been identified as one of the main reasons for damage of the IAN. ${ }^{18}$

Epker stressed the importance of minimal trauma to the IAN by modifying the way of approaching the medial site of the ascending ramus. He avoided the use of the channel retractor for the horizontal cut and recommended to limit the chiseling to a depth of $10 \mathrm{~mm}$. By exposing the coronoid process and by torqueing the two segments, he visualized and secured the neurovascular bundle at the mandibular foramen and inside the mandibular body before completing the split. ${ }^{3}$ The visualization of the lingula could be improved even more by removing the external cortex of the oblique line as suggested by Spiessl. ${ }^{19}$ Wolford added an inferior border osteotomy to the traditional technique leaving the posterior border of the ascending ramus as the only part that has to be split without being weakened by an osteotomy. This technique provides a more controlled split that causes bad splits less frequently. All these modifications have been 
established by clinical use and were not tested with in-vitro or in-vivo studies. We published several in-vitro studies about Wolford's modification by adding a caudal border osteotomy with promising results. Torque forces declined by $29 \%$ in pig cadaver mandibles and by $26 \%$ in human cadaver mandibles when using the modified technique compared to the traditional technique by Obwegeser Dal-Pont. In both species, the fracture lines are more precise and run along the posterior border of the ascending ramus than through the mandibular canal. Bad splits occurred less frequent although less torque is needed for the split. ${ }^{13,14}$

The preliminary result of the in-vivo study confirmed our in-vitro results. Although only 3 patients have been included into the study yet, we needed less torque to split the mandible if a fourth osteotomy was added. Furthermore, the fracture line resembled more the "classical" Obwegeser-Dal Pont split with a fracture line along the posterior border of the ascending ramus rather than the splitting result favored by Hunsuck with an osteotomy line running through the mandibular canal. Unfavorably more mucoperiostium has to be detached from the mandible to put the angled saw in the right place. Even so it is almost impossible to cut the whole inferior border of the mandibular body. The submandibular notch is the most distal part that could be reached with the saw by an intraoral approach. Nevertheless, no serious complication as axono- or neurotmesis of the inferior alveolar nerve or a bad split had occurred.

\section{CONCLUSION}

The traditional sagittal split technique by Obwegeser Dal-Pont with an additional inferior border osteotomy of the mandible provided reliable fractures of the mandible, at least comparable with the technique without the inferior border osteotomy. These first results encouraged us to proceed with the study. 


\section{REFERENCES}

1. Dal Pont G. L'osteotomia retromolare per la correzione della progenia. Minerva Chir. 1959;14:11381141.

2. Hunsuck EE. A modified intraoral sagittal splitting technic for correction of mandibular prognathism. J Oral Surg. 1968;26(4):250-253.

3. Epker BN. Modifications in the sagittal osteotomy of the mandible. J Oral Surg. 1977;35(2):157-159.

4. SpiessI B. Rigid internal fixation after sagittal split osteotomy of the ascending ramus. In: Spiessl B, ed. New concepts in maxillofacial bone surgery. Berlin, Heidelberg: Springer; 1976:115-122.

5. Wolford LM, Davis WM. The mandibular inferior border split: a modification in the sagittal split osteotomy. J Oral Maxillofac Surg. 1990;48(1):92-94.

6. Steenen SA, van Wijk AJ, Becking AG. Bad splits in bilateral sagittal split osteotomy: systematic review and meta-analysis of reported risk factors. Int J Oral Maxillofac Surg. 2016;45(8):971-979.

7. Steenen SA, Becking AG. Bad splits in bilateral sagittal split osteotomy: systematic review of fracture patterns. Int J Oral Maxillofac Surg. 2016;45(7):887-897.

8. Verweij JP, Mensink G, Fiocco M, van Merkesteyn JPR. Incidence and recovery of neurosensory disturbances after bilateral sagittal split osteotomy in different age groups: a retrospective study of 263 patients. Int J Oral Maxillofac Surg. 2016;45(7):898-903.

9. Agbaje JO, Gemels B, Salem AS, Anumendem D, Vrielinck L, Politis C. Modified mandibular inferior border sagittal split osteotomy reduces postoperative risk for developing inferior border defects. J Oral Maxillofac Surg. 2016;74(5):1062.e1-1062.e9.

10. Wolford LM. Influence of osteotomy design on bilateral mandibular ramus sagittal split osteotomy. J Oral Maxillofac Surg. 2015;73(10):1994-2004.

11. Gateno J, Ferraz F, Alfi D. Bad Split: anatomic or technical problem? J Oral Maxillofac Surg. 2015;73(6):1023-1024.

12. Agbaje JO, Salem AS, Lambrichts I, Jacobs R, Politis C. Systematic review of the incidence of inferior alveolar nerve injury in bilateral sagittal split osteotomy and the assessment of neurosensory disturbances. Int J Oral Maxillofac Surg. 2015;44(4):447-451.

13. Böckmann RA, Schön P, Frotscher M, Eggeler G, Lethaus B, Wolff K-D. Pilot study of modification of the bilateral sagittal split osteotomy (BSSO) in pig mandibles. J Craniomaxillofac Surg. 2011;39(3):169-172.

14. Böckmann RA, Schön P, Neuking K, Meyns J, Kessler PAWH, Eggeler G. In vitro comparison of the sagittal split osteotomy with and without inferior border osteotomy. J Oral Maxillofac Surg. 2015;73(2):316-323.

15. Plooij JM, Naphausen MTP, Maal TJJ, et al. 3D evaluation of the lingual fracture line after a bilateral sagittal split osteotomy of the mandible. Int J Oral Maxillofac Surg. 2009;38(12):1244-1249.

16. Obwegeser HL. Orthognathic surgery and a tale of how three procedures came to be: a letter to the next generations of surgeons. Clin Plast Surg. 2007;34(3):331-355.

17. Dal Pont G. Retromolar osteotomy for the correction of prognathism. J Oral Surg Anesth Hosp Dent Serv. 1961;19:42-47.

18. Teerijoki-Oksa T, Jääskeläinen SK, Forssell K, et al. Risk factors of nerve injury during mandibular sagittal split osteotomy. Int J Oral Maxillofac Surg. 2002;31(1):33-39.

19. Spiessl B. The sagittal splitting osteotomy for correction of mandibular prognathism. Clin Plast Surg. $1982 ; 9(4): 491-507$. 

Chapter

Discussion and future perspectives 

Since more than 150 years the disproportion of the human face has been subject to surgical interest. ${ }^{1}$ Initially, treatment planning was based mainly on occlusion and on profile of the face. The occlusal or skeletal deformity was corrected right at its location. ${ }^{1-3}$ It was Blair who for the first time involved orthodontists in the treatment. ${ }^{4}$

Around 1959 the lateral cephalogram was introduced to treatment planning ${ }^{5}$ and cephalometric analysis became an important part of the planning. ${ }^{6}$ With the sagittal and the axial dimension being measured at interval scale level, the third dimension, the coronal view, was still assessed by subjective estimation and favor at nominal scale level. Today this has changed with the high accessibility to tomograms. ${ }^{7,8}$ Now all points of the head could be localized to a reference point. ${ }^{9}$ The complexity of preoperative planning is transferred into the operation room by prefabricated splints. These splints are made either the conventional way by using plaster models or individually by $3 \mathrm{D}$ printing. Exact three-dimensional positioning of the maxilla as well as the proximal part of the mandible remains a difficult task. ${ }^{10}$ Even more sophisticated is the use of 3D navigation in the operation theatre. Initially developed for neurosurgical operations, ${ }^{11}$ it provides a large array of possibilities for the orthognathic surgeon. With the intraoperative navigation, the preoperative computer aided planning can be checked immediately during the procedure in the vertical, sagittal and transverse dimensions with an accuracy of about $1 \mathrm{~mm}$. $^{12,13}$

Although treatment can be planned to the millimeter, the evaluation of the operation technique itself remains empirical. Its evolution was rather complication driven than based on biomechanical research. Because of non-unions and relapses, the osteotomy of the mandibular body ${ }^{3}$ was abandoned in favor of the osteotomy of the ascending ramus. ${ }^{14}$ Blair's technique with an osteotomy through the neuro-vascular bundle was dropped in favor of nerve preserving techniques. ${ }^{15,16}$ Still the transbuccal approach left the facial nerve at risk and produced visible scars. Ernst was the first surgeon to dare an intraoral approach. ${ }^{17}$ It was Obwegeser who combined the intraoral approach with the sagittal split osteotomy to spare the facial and the inferior alveolar nerve and because of the huge overlapping segments prevented non-union. ${ }^{18}$ But risks such as a bad split, damage to the inferior alveolar nerve and relapse remained; all further modifications aimed at their reduction. ${ }^{19-23}$ Until today the quality of the different techniques have been assessed by documenting complication rates. In particular, the risk factors for a bad split are still unknown. Despite being the standard procedure for the osteotomy of the mandible for more than half of a century, new articles about the incidence of complications and how to avoid them are still being published. ${ }^{24-30}$

One reason might be the missing biomechanical evaluation of the sagittal split osteotomy; neither animal nor human cadaver studies or even tests in humans have ever been performed systematically.

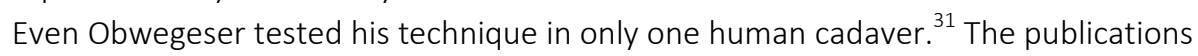
by Hunsuck, Epker and Wolford are technical notes. Hunsuck stated a successful treatment in 16 patients, Epker reported about 50 patients and Wolford used his technique 
in 150 patients. Comparative data with other techniques were unavailable at time of publication.

The construction of a test rack allowed us to study the splitting maneuver in an experimental scientific way. Torque did not differ in splitting 30 pig mandibles on both sides applying the Obwegeser-Dal Pont technique and the modification by Wolford, ${ }^{32}$ proving a valid test environment. No similar test had been set up until today. Verweij et al used a test device for their study ${ }^{33}$ but further explanation in particular over the freedom of movements of the mandible in their test setting is missing. Another article by Sofronia et al described failure mode and effect analysis for the design of a virtual reality-based simulator for bilateral sagittal split osteotomies. ${ }^{34}$ It is unknown if this project had ever been realized. Probably the algorithm to calculate the applied stress within the mandible was based on the finite element analysis (FEA).

FEA reduces large problems to smaller, more manageable pieces that are called finite elements. The physical interaction of these elements is described with equations. The more precise the equation describes the interaction with its surrounding elements, the better is the simulation of the whole problem. FEA was frequently used to calculate the stability of osteosynthesis. ${ }^{35-38}$ Some authors developed FEA models for the whole mandible. $^{39,40}$ The different shapes of the mandible, its numerous components like cortex, cancellous bone, the neuro-vascular bundle enclosed in the mandibular canal, impacted teeth or the roots of erupted teeth, each with its own physical deformation to stress and the interaction between all of them makes it extremely complicated to generate a valid model. For example, standard assumptions for the strength of cancellous layers differ largely from $0.2 \mathrm{GPa}^{38}$ up to $14.8 \mathrm{GPa}^{39}$

With the test rack, we were able to compare different techniques. The modifications by Hunsuck and Epker were not included in the comparison because they are only small modifications of the original technique by Obwegeser-Dal Pont. The hypothesis was that Wolford's modification with the additional forth osteotomy line will need less torque than the original technique. Likewise, it should produce better splitting results. We could confirm our hypothesis first in pig cadaver mandibles, ${ }^{32}$ later in human cadaver mandibles. ${ }^{41}$ Torque was reduced by about 29 percent in pig mandibles when using the fourth osteotomy, respectively about 26 percent in human cadaver mandibles. The lingual fracture line was more type I or type $\mathrm{II}^{42}$ thus more a classical Obwegeser or Hunsuck split. Verweij et al used a well-shorted inferior border osteotomy by using a 45degree design in the vertical osteotomy. ${ }^{33}$ The mechanical effect is very similar. The applied stress is guided towards the angle and the lingual cortex of the mandible. They stated significantly more type I and II lingual fracture lines compared with the Obwegeser splitting procedure.

Conclusively, the law of mechanics can be applied in inhomogeneous material as the human mandible with the irregularly deposited cortical and cancellous bone, the molar roots, and the mandibular canal in between. With this knowledge, focus was shifted from large scale to small scale. In place of adding an osteotomy, the shape of the oste- 
otomy itself was examined. From the mechanical point of view, a sharp-shaped osteotomy concentrates the stress in a small spot instead of distributing the stress over a larger area as in a round-shaped osteotomy. The hypothesis was that a sharp-shaped osteotomy by blade of a saw will render more control over the splitting procedure than the round-shaped osteotomy of the Lindemann burr. Until now the instruments used for the osteotomy depend on the surgeon's preference. No publications are known covering that question. Using pig mandibles in our test device, the torque necessary to split the mandible was significantly decreased by 17 percent in sharp-shaped osteotomies. ${ }^{43}$ A comparison of the lingual fracture pattern revealed an almost significant difference between splittings using a round shaped osteotomy with an incomplete fracture of the mandibular body and splittings based on sharp shaped osteotomy with a complete fracture.

This study was set up to shift the perspective away from the complications to the (bio-) mechanical problems of the sagittal split osteotomy. Improvement will demand a higher degree of standardization of the splitting procedure, e.g. only treatment of patients where wisdom teeth had been removed earlier or the specific use of instruments in preparation of the osteotomy lines. Furthermore, the surgeon should improve his skill by applying mechanical stress only after careful preparation of well-designed and wellpositioned osteotomy lines. The osteotomy of the inferior mandibular border plays an important role. By executing this part of the procedure carefully, even stress applied more cranially, e.g. above the mandibular canal will be directed into the inferior mandibular cortex and not into the buccal plate. Taking all these measures into account, it is less likely to damage the inferior alveolar nerve or to produce an unfavorable split. 


\section{REFERENCES}

1. Hullihen SP. Case of elongation of the underjaw and distorsion of the face and neck, caused by a burn, successfully treated. Am J Dent Sci. 1849;9:157-161.

2. Eiselsberg von A. Plastik bei Ektropium des Unterkiefers. Munch Med Wochenschr. 1907;54(1):36.

3. Eiselsberg von A. Über Plastik bei Ectropium des Unterkiefers. Wien Klin Wochenschr. 1906;19:1505.

4. Blair VP. Instances of operative correction of mal-relation of the jaws. International Journal of Orthodontia. 1915;1(8):395-421.

5. Köle H. Surgical operations on the alveolar ridge to correct occlusal abnormalities. Part I. Oral Surg Oral Med Oral Pathol. 1959;12(3):277-288.

6. Biederman $W$. The orthodontist's role in resecting the prognathic mandible. Am J Orthod. 1967;53(5):356-375.

7. Altobelli DE, Kikinis R, Mulliken JB, Cline H, Lorensen W, Jolesz F. Computer-assisted three-dimensional planning in craniofacial surgery. Plast Reconstr Surg. 1993;92(4):576-585.

8. Girod S, Keeve E, Girod B. Advances in interactive craniofacial surgery planning by 3D simulation and visualization. Int J Oral Maxillofac Surg. 1995;24(1 Pt 2):120-125.

9. Swennen GRJ, Mollemans W, Schutyser F. Three-dimensional treatment planning of orthognathic surgery in the era of virtual imaging. J Oral Maxillofac Surg. 2009;67(10):2080-2092.

10. Proffit WR, Turvey TA, Phillips $C$. The hierarchy of stability and predictability in orthognathic surgery with rigid fixation: an update and extension. Head Face Med. 2007;3(1):21.

11. Drake JM, Joy M, Goldenberg A, Kreindler D. Computer- and robot-assisted resection of thalamic astrocytomas in children. Neurosurgery. 1991;29(1):27-33.

12. Badiali G, Roncari A, Bianchi A, Taddei F, Marchetti C, Schileo E. Navigation in orthognathic surgery: 3D accuracy. Facial Plast Surg. 2015;31(5):463-473.

13. Sun Y, Luebbers H-T, Agbaje JO, Lambrichts I, Politis C. The accuracy of image-guided navigation for maxillary positioning in bimaxillary surgery. J Craniofac Surg. 2014;25(3):1095-1099.

14. Blair VP. Surgery and Diseases of the Mouth and Jaws. 1st ed. St. Louis: C.V. Mosby Company; 1912:242246.

15. Perthes GC. Operative Korrektur der Progenie. Zentralb/ Chir. 1922;49:1540-1541.

16. Kazanjian $\mathrm{VH}$. The treatment of mandibular prognathism with special reference to edentulous patients. Oral Surg Oral Med Oral Pathol. 1951;4(6):680-688.

17. Wassmund M. Die Formveränderungen der Kiefer. In: Lehrbuch der praktischen Chirurgie des Mundes und der Kiefer - Band 1. Vol 1. double sided copies. Leipzig: Hermann Meusser; 1935:245-308.

18. Trauner R, Obwegeser HL. The surgical correction of mandibular prognathism and retrognathia with consideration of genioplasty. I. Surgical procedures to correct mandibular prognathism and reshaping of the chin. Oral Surg Oral Med Oral Pathol. 1957;10(7):677-689.

19. Dal Pont G. Retromolar osteotomy for the correction of prognathism. J Oral Surg Anesth Hosp Dent Serv. 1961;19:42-47.

20. Hunsuck EE. A modified intraoral sagittal splitting technic for correction of mandibular prognathism. J Oral Surg. 1968;26(4):250-253.

21. Epker BN. Modifications in the sagittal osteotomy of the mandible. J Oral Surg. 1977;35(2):157-159.

22. Spiessl B. Rigid internal fixation after sagittal split osteotomy of the ascending ramus. In: Spiessl B, ed. New concepts in maxillofacial bone surgery. Berlin, Heidelberg: Springer; 1976:115-122.

23. Wolford LM, Davis WM. The mandibular inferior border split: a modification in the sagittal split osteotomy. J Oral Maxillofac Surg. 1990;48(1):92-94.

24. Steenen SA, van Wijk AJ, Becking AG. Bad splits in bilateral sagittal split osteotomy: systematic review and meta-analysis of reported risk factors. Int J Oral Maxillofac Surg. 2016;45(8):971-979.

25. Steenen SA, Becking AG. Bad splits in bilateral sagittal split osteotomy: systematic review of fracture patterns. Int J Oral Maxillofac Surg. 2016;45(7):887-897. 
26. Verweij JP, Mensink G, Fiocco M, van Merkesteyn JPR. Incidence and recovery of neurosensory disturbances after bilateral sagittal split osteotomy in different age groups: a retrospective study of 263 patients. Int J Oral Maxillofac Surg. 2016;45(7):898-903.

27. Agbaje JO, Gemels B, Salem AS, Anumendem D, Vrielinck L, Politis C. Modified mandibular inferior border sagittal split osteotomy reduces postoperative risk for developing inferior border defects. J Oral Maxillofac Surg. 2016;74(5):1062.e1-1062.e9.

28. Wolford LM. Influence of osteotomy design on bilateral mandibular ramus sagittal split osteotomy. J Oral Maxillofac Surg. 2015;73(10):1994-2004.

29. Gateno J, Ferraz F, Alfi D. Bad Split: anatomic or technical problem? J Oral Maxillofac Surg. 2015;73(6):1023-1024.

30. Agbaje JO, Salem AS, Lambrichts I, Jacobs R, Politis C. Systematic review of the incidence of inferior alveolar nerve injury in bilateral sagittal split osteotomy and the assessment of neurosensory disturbances. Int J Oral Maxillofac Surg. 2015;44(4):447-451.

31. Obwegeser HL. Orthognathic surgery and a tale of how three procedures came to be: a letter to the next generations of surgeons. Clin Plast Surg. 2007;34(3):331-355.

32. Böckmann RA, Schön P, Frotscher M, Eggeler G, Lethaus B, Wolff K-D. Pilot study of modification of the bilateral sagittal split osteotomy (BSSO) in pig mandibles. J Craniomaxillofac Surg. 2011;39(3):169-172.

33. Verweij JP, Mensink G, Houppermans P. Angled osteotomy design aimed to influence the lingual fracture line in bilateral sagittal split osteotomy: a human cadaveric study. J Oral Maxillofac Surg. 2015;73(10):1983-1993.

34. Sofronia RE, Knott T, Davidescu A, Savii GG, Kuhlen T, Gerressen M. Failure mode and effects analysis in designing a virtual reality-based training simulator for bilateral sagittal split osteotomy. Int J Med Robot. 2013;9(1):e1-e9.

35. Sato FRL, Asprino L, Fernandes Moreira RW, de Moraes M. Comparison of postoperative stability of three rigid internal fixation techniques after sagittal split ramus osteotomy for mandibular advancement. J Craniomaxillofac Surg. 2014;42(5):e224-e229.

36. Sindel A, Demiralp S, Colok G. Evaluation of different screw fixation techniques and screw diameters in sagittal split ramus osteotomy: finite element analysis method. J Oral Rehabil. 2014;41(9):683-691.

37. Bohluli B, Motamedi MHK, Bohluli P, Sarkarat F, Moharamnejad N, Tabrizi MHS. Biomechanical stress distribution on fixation screws used in bilateral sagittal split ramus osteotomy: assessment of 9 methods via finite element method. J Oral Maxillofac Surg. 2010;68(11):2765-2769.

38. Maurer P, Holweg S, Schubert J. Finite-element-analysis of different screw-diameters in the sagittal split osteotomy of the mandible. J Craniomaxillofac Surg. 1999;27(6):365-372.

39. van Rietbergen $B$, Weinans $H$, Huiskes $R$, Odgaard A. A new method to determine trabecular bone elastic properties and loading using micromechanical finite-element models. J Biomech. 1995;28(1):69-81.

40. Vollmer D, Meyer U, Joos U, Vègh A, Piffkò J. Experimental and finite element study of a human mandible. J Craniomaxillofac Surg. 2000;28(2):91-96.

41. Böckmann RA, Schön P, Neuking K, Meyns J, Kessler PAWH, Eggeler G. In vitro comparison of the sagittal split osteotomy with and without inferior border osteotomy. J Oral Maxillofac Surg. 2015;73(2):316-323.

42. Plooij JM, Naphausen MTP, Maal TJJ, et al. 3D evaluation of the lingual fracture line after a bilateral sagittal split osteotomy of the mandible. Int J Oral Maxillofac Surg. 2009;38(12):1244-1249.

43. Böckmann RA, Neuking K, Kessler PAWH. An In Vitro Comparison Study of the Use of a Drill or a Saw in the Hunsuck-Dal Pont Modification of the Obwegeser Sagittal Split Osteotomy in Pig Mandibles. J Oral Maxillofac Surg. 2017;75(8):1742.e1-1742.e9. 



\section{Valorisation Addendum}





\section{Introduction}

The most common facial deviations are mandibular retrognathism (the mandible is in a backward position in relation to the maxilla, creating an excessive overbite), prognathism (the mandible is in a forward position to the maxilla, creating a negative overbite or lantern jaw) or an open bite with no vertical overlap between the incisors. Prevalence depends mostly on genetical and racial background. Prognathism is found more frequently in Japanese, Chinese, and Korean people ${ }^{1,2}$ and less common in sub-Saharian Africans. ${ }^{3}$ Some prominent families like the Austrian royal family von Habsburg are well known for their typical facial appearance with a dominant, prognathic chin. ${ }^{4}$ In the US about $20 \%$ of the population is diagnosed with facial deviations, with $2 \%$ severe enough to be in need for surgical correction. ${ }^{5}$

Data about the prevalence of retrognathism are almost impossible to obtain. Proffit describes a ratio of 15 patients with retrognathism to one with prognathism in the United States. ${ }^{5}$ Retrognathism is frequently associated with an obstructive sleep apnea syndrome (OSAS) ${ }^{6}$ that can lead to an abundancy of severe negative effects in daily life. ${ }^{7}$ There is no broad-based study available about the prevalence of facial deviations in the Netherlands or in Europe. Some European studies on local populations report a prevalence of facial deviations of about $0.4-4 \%{ }^{8}$

The therapy of these deformations consists of orthodontic treatment in combination with surgical treatment, if indicated. Surgery corrects the position of the maxilla or mandible. The jaw in question is detached from the surrounding facial skeleton, then repositioned and re-fixated by means of osteosynthesis. The first surgical corrections were performed in the mandible in the beginning of the last century ${ }^{9,10}$. Nevertheless, serious complications such as facial palsy, non-union of the bone segments, numbness of the lip and chin, and skeletal relapse were common. ${ }^{11}$

The sagittal split osteotomy, which had been introduced in $1955,{ }^{12}$ is an operation technique in which the mandible is fractured without harming the inferior alveolar nerve that is embedded inside the mandibular body. Non-union of the bone segments is highly reduced due to large overlapping bone segments. The facial nerve does not have to be exposed, because of the exclusively intraoral approach. The disadvantage of this technique is the poor view of the operation field with a non-accessible posterior part of the mandible. As a consequence, the mandible may not fracture in the correct way (unfavorable split). However, within the last 50 years this operation technique became the golden standard to correct mandibular deviations. Several modifications of the original technique ${ }^{13-16}$ led to further improvements. Unfortunately, complications are still present nowadays as depleted lip and chin sensibility or the unfavorable split. The importance of the complications is obvious by the numerous publications over the last years. ${ }^{17-25}$ Both complications are linked with each other. The better the preparation of the planned fracture the more chiseling is necessary. Chiseling puts the inferior alveolar 
nerve at a higher risk of damage with possible more numbness of the lip and chin. Studying the bio-mechanics of the sagittal splitting procedure, as it is carried out in this thesis, helps to optimize the surgical technique and to reduce possible complications. Less complications result in a shorter hospitalization and a quicker recovery.

\section{Results}

The development of a test system enabled us to simulate the sagittal split osteotomy in-vitro. As it can be used in animal and human specimen alike resources can be used effectively in a responsible manner. This system offers the opportunity to explore different surgical techniques and to study the underlying biomechanical process in depth. If the planned fracture lines of the split are prepared with thin instruments, these fine cracks work as a stress riser. Thus, the split can be performed with smaller forces. Stress raising is a well-known phenomenon in material science and industrial design. Another aspect of this study is the validation of the inferior border osteotomy. Although difficult to approach in-vivo, it facilitates the splitting of the mandible substantially. It even allows the surgeon to spare the inferior alveolar nerve during the chiseling procedure. Keeping the nerve aside the risk of damage is reduced significantly, eventually reducing one of the most common complications of the sagittal split osteotomy, a persistent numbness of the lip and chin.

\section{Clinical Implications}

This study examined the particular surgical technique of the sagittal split osteotomy of the mandible. Because of its elegant, but nevertheless complicated nature, it remains one of the key operations in orthognathic surgery and in cranio-maxillofacial surgery. Orthognathic surgery comprises facial and orthodontic corrections in syndromal and non-syndromal patients, in patiens with cleft-lip-palate, but increasingly also corrections in OSAS patients. A safe and predictable therapy of these pathologies, as the modified sagittal split osteotomy is, reduces complications and consequently costs and morbidity.

\section{Sharing Knowledge}

One key-element in the facilitation of the sagittal split procedure is the addition of the inferior border osteotomy. Because of the limited access to this anatomical region special care and special designed instruments are necessary. To achieve this goal, this study was started in cooperation with the Institute of Material Science at Ruhr-University Bochum, Germany. High quality alloy was used to design a prototype of a rotating saw. It became evident that the material characteristics of Nickel-Titanium (NiTi) alloy, a shape memory alloy, could not sustain the mechanical stress of high speed rotation in combination with a strong curved steering, that was necessary due to the limited space 
available. Everybody learned from each other how to identify problems, tackle and solve them. All results have been commonly shared in scientific publications. They have been presented at national and international congresses and there will be more publications in the future.

\section{Future Perspectives}

One key element of this study was the development of a test rack to split cadaveric animal or human mandibles in-vitro. The validation showed reliable and reproducible results for both specimens. The data should allow for development and validation of a finite element method (FEM).

A reliable FEM does not exist at the moment, because of the complex structure of the human mandible. Different facts such as cancellous and cortical bone, roots of teeth, impacted molars, the alveolar canal with the inferior alveolar nerve enclosed and the interaction of all these components under stress prevented its development so far.

FEM transfers the test environment from the real world to a virtual one. It allows easier and cheaper testing. The individual split osteotomy can be pre-operatively tested. In addition to the clinical and scientific improvements, the FEM can be incorporated in the development of virtual reality facilities. These facilities will allow surgeons to learn, practice and improve their skills to perform a safe sagittal split osteotomy. 


\section{REFERENCES}

1. Allwright WC, Bundred WH. A survey of handcapping Dentofacial anomalies among Chinese in Hong Kong. Int Dent J. 1964;14:505-19.

2. Vioarsdóttir US, O'Higgins $\mathrm{P}$, Stringer $\mathrm{C}$. A geometric morphometric study of regional differences in the ontogeny of the modern human facial skeleton. J Anat. 2002;201(3):211-229.

3. Garner LD, Butt MH. Malocclusion in black American and Nyeri Kenyans. An epidemiologic study. Angle Angle Orthod. 1985;55(2):129-146.

4. Wolff $G$, Wienker TF, Sander H. On the genetics of mandibular prognathism: analysis of large European noble families. Journal of Medical Genetics. 1993;30(2):112-116.

5. Proffit WR, Fields HW, Moray $\amalg$. Prevalence of malocclusion and orthodontic treatment need in the United States: estimates from the NHANES III survey. Int I Adult Orthodon Orthognath Surg. 1998;13(2):97-106.

6. Schendel SA, Powell NB. Surgical orthognathic management of sleep apnea. I Craniofac Surg. 2007;18(4):902-911.

7. Verbraecken JA. OSAS: The Magnitude of the Problem. In: de Vries N, Ravesloot M, van Maanen JP, eds. Positional Therapy in Obstructive Sleep Apnea. Cham: Springer International Publishing; 2014:7-37.

8. Litton SF, Ackermann LV, Isaacson RJ, Shapiro BL. A genetic study of Class 3 malocclusion. Am J Orthod. 1970;58(6):565-577.

9. Blair VP. Instances of operative correction of mal-relation of the jaws. International Journal of Orthodontia. 1915;1(8):395-421.

10. Kazanjian VH. The Interrelation of Dentistry and Surgery in the Treatment of Deformities of the Face and Jaws. American Journal of Orthodontics and Oral Surgery. 1941;27(1):C10-C30.

11. Obwegeser HL. Orthognathic Surgery and a Tale of How Three Procedures Came to Be: A Letter to the Next Generations of Surgeons. Clin Plast Surg. 2007;34(3):331-355.

12. Trauner R, Obwegeser HL. Zur Operationstechnik bei der Progenie und anderen Unterkieferanomalien. Dtsch Zahn Mund Kieferheilkd. 1955;23:11-25.

13. Dal Pont G. Retromolar osteotomy for the correction of prognathism. J Oral Surg Anesth Hosp Dent Serv. 1961;19:42-47.

14. Epker BN. Modifications in the sagittal osteotomy of the mandible. J Oral Surg. 1977;35(2):157-159.

15. Hunsuck EE. A modified intraoral sagittal splitting technic for correction of mandibular prognathism. J Oral Surg. 1968;26(4):250-253.

16. Wolford LM, Bennett MA, Rafferty CG. Modification of the mandibular ramus sagittal split osteotomy. Oral Surg Oral Med Oral Pathol. 1987;64(2):146-155.

17. Posnick JC, Choi E, Liu S. Occurrence of a "bad" split and success of initial mandibular healing: a review of 524 sagittal ramus osteotomies in 262 patients. Int J Oral Maxillofac Surg. 2016;45(10):1187-1194.

18. Steenen SA, van Wijk AJ, Becking AG. Bad splits in bilateral sagittal split osteotomy: systematic review and meta-analysis of reported risk factors. Int J Oral Maxillofac Surg. 2016;45(8):971-979.

19. Steenen SA, Becking AG. Bad splits in bilateral sagittal split osteotomy: systematic review of fracture patterns. Int J Oral Maxillofac Surg. 2016;45(7):887-897.

20. Verweij JP, Mensink G, Fiocco M, van Merkesteyn JPR. Incidence and recovery of neurosensory disturbances after bilateral sagittal split osteotomy in different age groups: a retrospective study of 263 patients. Int J Oral Maxillofac Surg. 2016;45(7):898-903.

21. Gateno J, Ferraz F, Alfi D. Bad Split: Anatomic or Technical Problem? J Oral Maxillofac Surg. 2015;73(6):1023-1024.

22. Agbaje JO, Salem AS, Lambrichts I, Jacobs R, Politis C. Systematic review of the incidence of inferior alveolar nerve injury in bilateral sagittal split osteotomy and the assessment of neurosensory disturbances. Int J Oral Maxillofac Surg. 2015;44(4):447-451. 
23. Verweij JP, Mensink G, Fiocco M, van Merkesteyn RJPR. Presence of mandibular third molars during bilateral sagittal split osteotomy increases the possibility of bad split but not the risk of other postoperative complications. J Craniomaxillofac Surg. 2014;42(7):E359-E363.

24. Mensink G, Zweers A, Wolterbeek R, Dicker GJ, Groot RH, van Merkesteyn RJPR. Neurosensory disturbances one year after bilateral sagittal split osteotomy of the mandibula performed with separators: a multi-centre prospective study. J Craniomaxillofac Surg. 2012;40(8):763-767.

25. Santos T de S, Albuquerque KM, Sousa Maciel Santos ME, Laureano Filho JR. Survey on Complications of Orthognathic Surgery Among Oral and Maxillofacial Surgeons. J Craniofac Surg. 2012;23(5):E423-E430. 

Summary 

The thesis examined the biomechanics of the sagittal split osteotomy in-vitro and in-vivo. The traditional technique by Obwegeser-Dal Pont was compared with the modification by Wolford, who added an osteotomy to the inferior border of the mandible. Tests were done in-vitro in animal and human cadavers and in-vivo in humans. Additionally, the effect of the instruments used for the osteotomy were examined by comparing the sagittal split performed with a rotating burr with an oscillating saw. The acquired data was used to detect the most critical steps in the procedure of the sagittal split osteotomy.

Chapter 1 introduces the technique of the sagittal split osteotomy by giving a short overview about the history of orthognathic surgery and its preliminary end of development with the introduction of the sagittal split of the ascending ramus. This technique prevents visible scaring and damage to the facial and trigeminal nerve. Complications such as damage to the inferior alveolar nerve and the unfavorable split remained, despite numerous modifications by Dal-Pont, Hunsuck, Epker, and Wolford. Today the most common complication is the impairment of the inferior alveolar nerve due to neuropraxia, axonotmesis or neurotmesis resulting in a deteriorated sensibility of the lower lip and the chin area. In addition, there is the risk of an unfavorable split, with the fracture of the buccal cortex being the most common incidence and with the condylar fracture as the most difficult one to treat by an intraoral approach.

The review in chapter 2 describes the history of the sagittal split osteotomy intended to correct skeletal deformities often in combination with occlusional aberrations. Beginning with Hullihen's osteotomy of the mandibular front segment in 1849, the most important inventions by Blair, Eiselberg, Perthes and Schlössmann, Kostečka, Kazanjian and Schuchardt are enlisted until Hugo Obwegeser introduced the sagittal split osteotomy. Due to the complications, as damage to the inferior alveolar nerve, bad splits and relapse, that still occurred, numerous modifications of the sagittal split osteotomy had been introduced. Dal Pont enlarged the overlapping bone segments to prevent nonunion by relocating the proximal osteotomy in the anterior direction. Hunsuck shortened the horizontal osteotomy to prevent excessive tunneling of the lingual pterygomandibular space. By doing so he avoided stress and damage to the inferior alveolar nerve at its entrance in the mandibular foramen. Stabilization of the segments by wire the modification by Epker was primarily intended to keep the condyle in the correct position - prevented sagging and relapse. Following the $\mathrm{AO}$ guidelines, first Spiessl, later Steinhäuser, Bell (screws) and Michelet (mini plates) introduced the internal rigid osseofixation of the two segments. Its use superseded the inconvenience of long-lasting intermaxillary fixation and it helped to prevent relapse by adding more stability to the two segments. The last significant alteration was the addition of the inferior border osteotomy of the mandible by Wolford. This had probably the most significant impact on the biomechanics of the sagittal split of all modifications. The review ends with the first 
biomechanical studies of the sagittal split osteotomy by Böckmann, which are the subject of this thesis.

This article was awarded as "Best Regional Paper 2015 - Europe" by the editors of "Plastic Reconstructive Surgery GO".

Chapter 3 describes the effects of adding an inferior border osteotomy to the traditional sagittal split osteotomy in pig cadaver mandibles by using a self-constructed test setup. The test rack was validated by splitting 30 mandibles bilaterally with the same technique. Sixteen mandibles were split bilaterally using the traditional technique by Obwegeser-Dal Pont. The torque force that was necessary to split the mandible was measured and compared to the other side. The correlation between the two sides was 0.96 with no significant difference. Then 14 mandibles were split using the Obwegeser-Dal Pont technique with an additional inferior border osteotomy. This test revealed the same result with a non-significant difference of $0.01 \mathrm{Nm}$ between both sides proving the test setting as reliable.

In a split-mouth model, another 70 pig mandibles were split sagittally. One side was split using the traditional Obwegeser-Dal Pont technique, the contralateral side was split using the Obwegeser-Dal Pont technique with an additional osteotomy of the inferior mandibular border. The average torque necessary to complete the split was 2.10 $\mathrm{Nm}$ for the Obwegeser-Dal Pont technique and $1.50 \mathrm{Nm}$ for the modified technique. This difference was significant.

In chapter 4, a split-mouth model in 70 pig cadaver mandibles was used to compare the lingual fracture lines of a sagittal split osteotomy between the traditional ObwegeserDal Pont technique and the same technique with an additional mandibular border osteotomy. Using the Obwegeser-Dal Pont technique, 100\% of all fractures ran through the mandibular canal. After adding an inferior border osteotomy to the traditional technique, $75 \%$ could be classified as ideal Hunsuck-like fracture pattern with the remaining $25 \%$ showing the already mentioned fracture pattern through the mandibular canal.

The splitting results of the Obwegeser-Dal Pont technique compared to the same technique with the additional inferior border osteotomy in 35 human cadaver mandibles are reported in chapter 5 . In a split-mouth model, one side of the mandible was split according to Obwegeser-Dal Pont and the contralateral side of the mandible was split using the same technique with an osteotomy of the inferior mandibular border. The torque forces were recorded during the splitting procedure and the lingual fracture line was classified according to the classification of Plooij. Torque was significantly reduced by $26 \%$ adding the inferior border osteotomy. Three quarters of all split mandibles fractured along the inferior mandibular border when using the modified technique resulting in a type I or II fracture pattern. When using the Obwegeser-Dal Pont technique, about 
$2 / 3$ of all lingual fractures ran through the mandibular canal (type III) leaving the rest to type I, II (Obwegeser or Hunsuck fracture pattern) or IV (bad split) fractures.

Chapter 6 describes the results of the Obwegeser-Dal Pont splitting procedure depending on using a rotating instrument or an oscillating instrument for the osteotomies. This study was based on the hypothesis that the stress of the torque is better concentrated in sharp-edged osteotomies than in round-shaped osteotomies. If a saw was used to create sharp edged osteotomies, $16 \%$ less torque was needed to split a pig cadaver mandible compared to a sagittal splitting with round shaped osteotomies created by a Lindemann burr. Splitting prepared with the oscillating saw had more complete splits than the group where the osteotomies had been prepared with a rotating burr.

Transferring the in-vitro results into clinical practice, chapter 7 summarizes the first preliminary results in a randomized prospective clinical study in humans, where in a split-mouth model one side of the mandible was split with the Obwegeser-Dal Pont technique, and the contralateral side was split using the Obwegeser-Dal Pont technique with an inferior border osteotomy. The results confirmed the use of a more predefined split. With the additional inferior border osteotomy, the lingual fracture ran closer towards the posterior border of the ascending ramus compared to the traditional technique as seen on post-operative cone-beam computed tomography scans. General torque forces necessary to split the mandibles ranged from $0.9 \mathrm{Nm}$ to $2.38 \mathrm{Nm}$. About $14 \%$ less torque was necessary to complete the sagittal split on the side with the additional inferior border osteotomy. These results are encouraging to proceed with this technique.

Above findings are discussed in chapter 8. Although orthognathic surgery has been introduced about 150 years ago and although operation techniques have been readjusted multiple times, orthognathic surgery remains a procedure associated with complications. The introduction of the sagittal split osteotomy was a break-through regarding the surgical re-positioning of the mandible. This technique eliminated some of the most feared complications as facial palsy or non-union of the bony segments. Other complications such as numbness of the lip and chin or the risk of an unfavorable split remained. Although the technique has been modified several times the risks are still present today. To date, all modifications were evaluated only by clinical reviews. With the development of a test rack that is suited for animal and human specimen, the evaluation of the surgical procedure was transferred from the operation room into the laboratory. The test rack provides reproducible standardized conditions and the visualization of the bio-mechanics of the splitting procedure. Adding an inferior border osteotomy to the traditional technique facilitates the splitting significantly. Furthermore, the use of fine instruments for the osteotomies works as a stress raiser during the split. The applied forces are concentrated on smaller spots, which makes the fracturing process more controllable. 


\section{Valorisation}

By taking the surgical technique from the operation room to the test bench, it is possible to repeat and measure parameters in detail. In-vitro and in-vivo studies proved that the sagittal split osteotomy with an additional inferior border osteotomy is more reliable. The modification results in fewer complications and quicker recovery of the patients. The next step is the transfer from the bench to a virtual environment by establishing a finite element analysis and creating a finite element method. This method enables to test different types of the sagittal split osteotomy easily. Moreover, after acquiring the individual data-set of the patient's mandible the operation could be performed virtually before going to the theatre, making the surgeon aware of possible pitfalls in an individual case. A close collaboration with software and mechanical engineering is required to achieve this goal. 
Samenvatting 

In dit proefschrift wordt de biomechanica van de sagittale splijtingsosteotomie in-vitro en in-vivo bestudeerd. De traditionele techniek volgens Obwegeser-Dal Pont wordt vergeleken met de modificatie volgens Wolford, die een osteotomielijn aan de onderrand van de mandibula toevoegde. In-vitro werden experimenten gedaan op dierlijke en humane kadavers, daarna werd de studie voorgezet in-vivo bij mensen. Daarnaast werd het effect van het gebruikte instrumentarium voor de osteotomie onderzocht. Er werd vergeleken tussen de sagittale splijting die werd aangezet door ronddraaiend instrumentarium en door oscillerend instrumentarium. De verkregen data werden gebruikt om de meest kritische stappen in het proces van de sagittale splijtingsosteotomie te identificeren.

Hoofdstuk 1 beschrijft de techniek van de sagittale splijtingsosteotomie van de onderkaak aan de hand van een kort chronologisch overzicht van de orthognatische chirurgie en het voorlopige einde van de ontwikkeling hiervan. Dit einde werd gekenmerkt door de introductie van de sagittale splijting van de ramus ascendens mandibulae. Deze techniek moest zichtbare littekens en schade aan de nervus facialis en nervus trigeminus voorkomen. Complicaties zoals schade aan de nervus alveolaris inferior of een ongunstige splijting van de mandibula bestaan heden ten dage echter nog steeds ondanks de vele modificaties door Dal Pont, Hunsuck, Epker en Wolford. Tegenwoordig is het meest voorkomende restletsel functieverlies van de nervus alveolaris inferior in de vorm van neuropraxie, axonotmesis of neurotmesie. Allen resulterend in verminderde sensibiliteit van de onderlip en kin. Daarnaast bestaat het risico op een ongunstige splijting van de mandibula. Meest voorkomend is een fractuur van de buccale cortex. Een fractuur van het collum mandibulae is het lastigste te behandelen via een intra-orale benadering.

Hoofdstuk 2 beschrijft de historie van de sagittale splijtingsosteotomie ter correctie van skeletale afwijkingen die vaak in combinatie voorkomen met occlusiestoornissen. Startend bij de osteotomie van het frontsegment door Hullihen in 1849 worden de belangrijkste ontwikkelingen door Blair, Eiselberg, Perthes en Schlössman, Kostečka, Kazanjian and Schuchardt besproken tot aan de introductie van de sagittale splijtingsosteotomie door Hugo Obwegeser. Vanwege de nog immer optredende complicaties zoals letsel van de nervus alveolaris inferior, ongunstige splijting en relapse werden talrijke modificaties op de sagittale splijtingsosteotomie geïntroduceerd. Ter preventie van nonunions verlengde Dal Pont de afstand van de overlappende botsegmenten door de proximale osteotomie naar anterieur te verplaatsen. Hunsuck verkortte de horizontale osteotomie om de manipulatie in de ptergygomandibulaire ruimte te verkleinen waardoor rek en schade aan de nervus alveolaris inferior op de intredeplaats in het foramen mandibulae werd beperkt. Epker modificeerde de techniek door de segmenten te stabiliseren door middel van een draadligatuur, dit was voornamelijk bedoeld om de condylus in de juiste positie te houden en om verzakking en relapse te voorkomen. De aan- 
hangers van de AO-filosofie introduceerden de interne rigide fixatie van de twee botsegmenten. Eerst door Spiessl, daarna Steinhäuser, Bell (schroeffixatie) en Michelet (mini plates). Het gebruik van osteosynthesemateriaal verving de onvriendelijke, langdurige intermaxillaire fixatie en hielp relapse te voorkomen door meer stabiliteit aan de twee fragmenten te geven. De laatste significante modificatie van de jarenlang bestaande osteotomie techniek van de onderkaak was de toevoeging van een osteotomie aan de onderrand van de mandibula door Wolford. Deze wijziging heeft van alle modificaties waarschijnlijk het grootste effect op de biomechanica van de sagittale splijting. De review eindigt met de eerste biomechanische studies van de sagittale splijtingsosteotomie door Böckmann, die het onderwerp zijn van dit proefschrift.

Dit artikel werd door de editors van "Plastic Reconstructive Surgery GO" verkozen tot "Best Regional Paper 2015 - Europe".

Hoofdstuk 3 beschrijft het effect van toevoeging van een osteotomie van de onderrand van de mandibula aan de traditionele sagittale splijtingsosteotomie op de kracht die nodig is om de mandibula te splitsen. Dit werd gedaan in kadaver varkenskaken in een zelf ontworpen proefopstelling. Voor validatie van de opstelling werden 30 varkens mandibulae bilateraal gespleten met dezelfde techniek. Zestien mandibulae werden beiderzijds gesplitst met de traditionele techniek beschreven door Obwegeser-Dal Pont. De kracht die nodig was voor de splijting werd gemeten aan beide zijden. De correlatie tussen de twee zijden was 0.96 zonder significant verschil. Vervolgens werden 14 varkens mandibulae beiderzijds gesplitst middels dezelfde techniek met toevoeging van osteotomie van de onderrand. Dit liet dezelfde resultaten zien met een niet-significant verschil in kracht van $0.01 \mathrm{Nm}$ tussen beide zijden. De proefopstelling bleek daarmee betrouwbaar. In een split-mouth model werden 70 kadaver varkenskaken sagittaal gesplitst. Eén zijde werd gesplitst met de traditionele techniek van Obwegeser-Dal Pont. De contralaterale zijde werd gesplitst middels de traditionele techniek van ObwegeserDal Pont met toevoeging van osteotomie van de onderrand. De gemiddelde rotatiekracht nodig voor de splijting was $2.10 \mathrm{Nm}$ voor de Obwegeser-Dal Pont techniek en $1.50 \mathrm{Nm}$ voor de gemodificeerde techniek. Dit verschil was statistisch significant.

In hoofdstuk 4 worden de resultaten besproken van een split-mouth model in 70 kadaver varkenskaken, waarin het linguale fractuurpatroon na sagittale splijtingsosteotomie werd onderzocht. Aan één zijde werd de traditionele Obwegeser-Dal Pont techniek gebruikt en aan de contralaterale zijde de traditionele Obwegeser-Dal Pont techniek met een toegevoegde osteotomie van de onderrand. Gebruikmakend van de Obwegeser-Dal Pont techniek verliep $100 \%$ van de fractuurlijnen door de canalis mandibulae. $\mathrm{Na}$ toevoegen van een osteotomie van de onderrand kon $75 \%$ van de fracturen worden geclassificeerd als ideale splijting volgens Hunsuck. De resterende $25 \%$ liet een fractuurpatroon door de canalis mandibulae zien zoals bij de Obwegeser-Dal Pont techniek. 
Het resultaat van splijting volgens de Obwegeser-Dal Pont techniek, vergeleken met dezelfde techniek inclusief een toegevoegde osteotomie van de onderrand uitgevoerd in 35 humane kadaver mandibulae wordt beschreven in hoofdstuk 5. In een split-mouth model werd eenzijdig van de mandibula gesplitst volgens de Obwegeser-Dal Pont techniek. De contralaterale zijde werd gesplitst volgens dezelfde techniek met een toegevoegde osteotomie van de onderrand. De kracht nodig voor de splijting werd gemeten en het verloop van de linguale fractuur beoordeeld volgens de classificatie volgens Plooij. De benodigde kracht bleek 26\% lager in de groep met de toegevoegde osteotomie van de onderrand, een significant verschil. In 3/4 van de splijtingen volgens de gemodificeerde techniek verliep de fractuurlijn via de onderrand van de mandibula resulterend in een type I of II fractuurpatroon. Wanneer de standaard Obwegeser-Dal Pont techniek werd gebruikt verliep ongeveer 2/3 van alle linguale fracturen door de canalis mandibulae (type III). De overige fractuurpatronen waren een type I, II (Obwegeser of Hunsuck fractuurpatroon) of IV (bad split).

Hoofdstuk 6 beschrijft de resultaten van de Obwegeser-Dal Pont splijtingsprocedure afhankelijk van het gebruik van een ronddraaiend instrument (Lindemann boor) of er een oscillerend instrument (oscillerende zaag) voor verrichten van osteotomieën. Deze studie was gebaseerd op de hypothese dat de uitgeoefende kracht tijdens splijting zich meer concentreert in osteotomieën met scherpe hoeken (oscillerende zaag) dan in osteotomieën met ronde hoeken (Lindemann boor). In kadaver varkenskaken bleek dat er $16 \%$ minder kracht nodig is om een splijting te bewerkstelligen wanneer een osteotomie met scherpe hoeken (oscillerende zaag) werd vergeleken met een osteotomie met ronde hoeken (Lindemann boor). Osteotomieën geprepareerd met de oscillerende zaag lieten een meer complete splijting zien dan de osteotomieën die waren voorbereid met een ronddraaiend instrument.

De resultaten uit het in-vitro onderzoek worden in hoofdstuk 7 vertaald naar de kliniek. De eerste resultaten van een gerandomiseerde prospectieve klinische studie in de mens worden beschreven. Hierbij werd gebruikt gemaakt van een split-mouth model. Aan één zijde werd de traditionele techniek door Obwegeser Dal-Pont gebruikt. Aan de andere zijde de gemodificeerde Obwegeser Dal-Pont techniek met een toegevoegde osteotomie van de onderrand. De resultaten pleiten voor het uitvoeren van een beter voorbereide osteotomie alvorens te splijten. Bij de techniek met toegevoegde osteotomie van de onderrand werd op postoperatieve cone-beam ct scans gezien dat de linguale fractuur meer naar de achterrand van de ramus ascendens mandibulae verloopt in vergelijking met de traditionele techniek. De kracht die nodig was om de mandibula te splijten liep uiteen van $0.9 \mathrm{Nm}$ tot $2.38 \mathrm{Nm}$. Er is $14 \%$ minder kracht nodig om de sagittale splijting aan de zijde met de toegevoegde osteotomie van de onderrand te bewerkstelligen. Deze resultaten zijn bemoedigend voor het verder ontwikkelen en blijven gebruiken van deze techniek. 
In hoofdstuk 8 worden bovenstaande resultaten besproken. Hoewel de orthognatische chirurgie al 150 jaar geleden zijn aanvang nam en de operatietechnieken in de loop der jaren regelmatig aangepast werden ontstaan er heden ten dage nog steeds de nodige complicaties. De introductie van de sagittale splijtingsosteotomie was een doorbraak voor wat betreft de repositie van de onderkaak. Deze techniek elimineerde de meest gevreesde complicaties zoals aangezichtsverlamming of het uitblijven van consolidatie van de botsegmenten. Andere complicaties zoals verminderde sensibiliteit van onderlip en kin of het risico van een niet gewenste splijting bleven bestaan. En ondanks verscheidene modificaties in de loop der jaren bleven deze risico's bestaan. Tot op heden werden alle modificaties van de originele splijtingsosteotomie alleen klinisch beoordeeld. Met de ontwikkeling van de eerder beschreven proefopstelling die geschikt is voor dierlijke en menselijke preparaten is de beoordeling van de chirurgische procedure ook mogelijk in het laboratorium. Gebruik van deze proefopstelling staat garant voor gestandaardiseerde condities en visualisering van de biomechanica van het splijtingsproces van de mandibula. Het toevoegen van een osteotomie aan de onderrand vergemakkelijkt de splijting aanzienlijk. Daarnaast zorgt een smalle osteotomielijn door het gebruik van fijn instrumentarium voor minder spreiding van de kracht uitgeoefend tijdens de splijting. De uitgeoefende krachten worden op een kleiner oppervlak geconcentreerd waardoor het breken van het bot beter te controleren is.

\section{Valorisatie}

Door de operatietechniek vanuit de operatiekamer naar de proefopstelling te verplaatsen is het mogelijk om de parameters zorgvuldig te meten en gestandaardiseerd te herhalen. In-vitro en in-vivo studies bewijzen dat een sagittale splijtingsosteotomie mét de toegevoegde osteotomie van de onderrand betrouwbaarder is. Deze gemodificeerde osteotomie geeft minder complicaties en bevordert een sneller herstel van de patiënt. De volgende stap is de overgang van de testopstelling naar de virtuele wereld door het berekenen van de e.e.a. (eindige-elementenanalyse) en het ontwikkelen van een e.e.m. (eindige-elementenmethode). Daarmee zou aan de hand van de gegevens van de onderkaak van de patiënt de ingreep virtueel uitgevoerd kunnen worden voor de daadwerkelijke ingreep zodat de operateur voorbereid is op de mogelijke valkuilen van iedere individuele casus.

Om dit doel te bereiken is een zeer goede samenwerking tussen softwarespecialisten, technisch ingenieurs en medici noodzakelijk. 


\section{Other publications}


1. Gellrich N-C, Schramm A, Böckmann RA, Kugler J. Follow-up in patients with oral cancer. J Oral Maxillofac Surg. 2002;60(4):380-386.

2. Wolff K-D, Swaid S, Nolte D, Böckmann RA, Hölzle F, Müller-Mai C. Degradable injectable bone cement in maxillofacial surgery: indications and clinical experience in 27 patients. J Craniomaxillofac Surg. 2004;32(2):71-79.

3. Wolff K-D, Böckmann RA, Nolte D, Wysluch A, Hölzle F. [Limitations of blood supply to the skin flap in face lift surgery]. Mund Kiefer GesichtsChir. 2005;9(1):1-5.

4. Böckmann RA, Schulz T, Stein H, et al. Bilateral synchronous submandibular lumps in a patient with gastric carcinoma. J Oral Pathol Med. 2005;34(2):127-128.

5. Wolff K-D, Kesting MR, Thurmüller P, Böckmann RA, Hölzle F. The early use of a perforator flap of the lateral lower limb in maxillofacial reconstructive surgery. Int J Oral Maxillofac Surg. 2006;35(7):602-607.

6. Wolff K-D, Kesting MR, Thurmüller P, Böckmann RA, Hölzle F. The anterolateral thigh as a universal donor site for soft tissue reconstruction in maxillofacial surgery. J Craniomaxillofac Surg. 2006;34(6):323-331.

7. Frotscher A, Neuking K, Böckmann RA, Wolff K-D, Eggeler G. In situ scanning electron microscopic study of structural fatigue of struts, the characteristic elementary building units of medical stents. Materials Science and Engineering a-Structural Materials Properties Microstructure and Processing. 2008;481:160-165.

8. Frotscher M, Noertershaeuser P, Somsen C, Neuking K, Böckmann RA, Eggeler G. Microstructure and structural fatigue of ultra-fine grained NiTi-stents. Materials Science and Engineering a-Structural Materials Properties Microstructure and Processing. 2009;503(1-2):96-98.

9. Frotscher M, Burow J, Schön P, Neuking K, Böckmann RA, Eggeler G. Characterization of the mechanical properties of ultra-fine grained NiTiCr-wires. Materialwissenschaft Und Werkstofftechnik. 2009;40(1-2):17-22.

10. Loeffelbein DJ, Nieberler M, Steinstraesser L, Böckmann RA, Hoelzle F, Wolff K-D, Kesting MR. Effects of ciclosporin therapy on xylazine/ketamine anaesthesia in a rat model. J Vet Pharmacol Ther. 2010;33(1):100-102.

11. Böckmann RA, Schön P, Frotscher M, Eggeler G, Lethaus B, Wolff K-D. Pilot study of modification of the bilateral sagittal split osteotomy (BSSO) in pig mandibles. J Craniomaxillofac Surg. 2011;39(3):169-172.

12. Schön P, Frotscher M, Eggeler G, Kessler PAWH, Wolff K-D, Böckmann RA. Modification of the bilateral sagittal split osteotomy (BSSO) in a study using pig mandibles. Int J Oral Maxillofac Surg. 2011;40(5):516-520. 
13. Lethaus B, Poort LJ, Böckmann RA, Smeets R, Tolba R, Kessler PAWH. Additive manufacturing for microvascular reconstruction of the mandible in 20 patients. J Craniomaxillofac Surg. 2012;40(1):43-46.

14. Böckmann RA, Lethaus B, Schön P, Mielke E, Kessler PAWH, Stricker I. A bilateral cervical swelling and it is not a malignancy. Oral Surg Oral Med Oral Pathol Oral Radiol. 2012;113(6):e19-e21.

15. Kessler PAWH, Poort LJ, Böckmann RA, Lethaus B. Definition of quality indicators in microsurgery in head and neck reconstruction based on a 5-year follow-up without a loss. J Craniomaxillofac Surg. 2013;41(1):2-6.

16. Lethaus B, Poort L, Yamauchi K, Kloss-Brandstätter A, Böckmann RA, Kessler PAWH. Qualitative bone CT as a tool to assess vascularization in irradiated bone: an animal study. Clin Oral Implants Res. 2013;24(7):746-749.

17. Buurman DJM, Vaassen LA, Böckmann RA, Kessler PAWH. Prosthetic rehabilitation of head and neck cancer patients focusing on mandibular dentures in irradiated patients. Int J Prosthodont. 2013;26(6):557-562.

18. Poort LJ, Bittermann GKP, Böckmann RA, et al. Does a change in bone mineral density occur in the mandible of Göttingen minipigs after irradiation in correlation with radiation dose and implant surgery? J Oral Maxillofac Surg. 2014;72(11):2149-2156.

19. Bloebaum M, Poort LJ, Böckmann RA, Kessler PAWH. Survival after curative surgical treatment for primary oral squamous cell carcinoma. J Craniomaxillofac Surg. 2014;42(8):1572-1576.

20. Böckmann RA, Meyns J, Dik E, Kessler PAWH. The modifications of the sagittal ramus split osteotomy: a literature review. Plastic \& Reconstructive Surgery Global Open. 2014;2(12):e271.

21. Böckmann RA, Schön P, Neuking K, Meyns J, Kessler PAWH, Eggeler G. In-vitro comparison of the sagittal split osteotomy with and without inferior border osteotomy. $J$ Oral Maxillofac Surg. 2015;73(2):316-323.

22. Poort LJ, Bloebaum MMF, Böckmann RA, et al. Assessment of local blood flow with laser Doppler flowmetry in irradiated mandibular and frontal bone, an experiment in Göttingen minipigs. J Craniomaxillofac Surg. 2015;43(10):2071-2077. 



\section{Curriculum vitae}

Roland August Böckmann was born on April $12^{\text {th }}, 1970$ in Krefeld, Germany. He attended high school at the Fichte-Gymnasium at Krefeld and graduated in 1989. He attended conscripted military service from 1989 to 1990. Afterwards he studied medicine at the Ruhr-University at Bochum, Germany from 1990 to 1997. He enrolled in dentistry at the Friedrich-Wilhelm-University at Bonn, Germany in 1997 and graduated in 2001. From 2001 until 2005 he specialised in maxillofacial surgery at the Department of Oral and Maxillofacial Plastic Surgery at Knappschaftskrankenhaus Bochum, Germany, under supervision of Prof. Dr Dr K.-D. Wolff, where he continued to work as a registrar from 2006 until 2009. Since 2009 he works as a Senior Physician and Vice Medical Director at Maastricht University Medical Centre (Head: Prof. Dr Dr P. Kessler). 

Dankwoord 
De totstandkoming van dit proefschrift heb ik mede te danken aan een aantal bijzondere mensen in mijn omgeving. Het was een leerzaam traject, waarbij mijn wetenschappelijke ontwikkeling wellicht in het niet valt bij al het andere dat ik gedurende deze tijd heb geleerd. Het is mij een voorrecht om deze mensen te bedanken:

Prof. dr. dr. P.A.W.H. Kessler, hooggeleerde promotor. Mijn dank aan u is groot omdat u me bij het voortzetten en uitbreiden van het onderzoeksproject in Maastricht op een uitstekende manier heeft ondersteund. Op wetenschappelijk en klinisch vlak bent u een goed mentor. Het is geweldig om te zien dat dit onderzoek tot deze promotie heeft geleid.

Prof. dr. dr. K.-D. Wolff, hooggeleerde co-promotor. Dankzij uw inzet mocht ik met het onderzoek in Bochum beginnen. $U$ was tijdens mijn eerste stappen in de wetenschappelijke wereld een betrouwbaar begeleider, waarvoor mijn dank.

Prof. dr. dr. Stephaan Bergé, hooggeleerde co-promotor, beste Stefaan. Op jouw advies heb ik toentertijd in Bochum naar een opleidingsplaats gesolliciteerd. Dat was de eerste steen van deze hele promotie. Dank voor de goede en zeer gewaardeerde adviezen vóór en tijdens het promotietraject.

Leden van de beoordelingscommissie: Prof. dr. L.W. van Rhijn, voorzitter, Prof. dr. A.G. Becking, Prof. dr. A. Herrler, Prof. dr. dr. G. Swennen en Prof. dr. J.E. Wildberger. Ik ben $\mathrm{u}$ allen zeer erkentelijk voor het beoordelen van dit proefschrift. Dank dat U uw waardevolle tijd hiervoor heeft willen inzetten.

Mede-onderzoekers Prof. dr. Eggeler, dr. Patrick Schön, dr. Matthias Frotscher en dr. Klaus Neuking: zonder jullie hulp zou ik überhaupt nooit aan dit onderzoek zijn begonnen. Het was een prachtige samenwerking, dank voor jullie tijd, energie en commitment.

Drs. Joeri Meyns en drs. Nynke Lie. Dank voor jullie bijdragen aan dit onderzoek en de fijne samenwerking.

Marie-José Verheijen-Blomme: Vanaf het moment dat ik in Maastricht ben begonnen heb je mij met raad en daad gesteund. Samen gingen we twee keer voor vrijwilligerswerk naar Lombok, Indonesië, waar ik veel heb beleefd en geleerd. Evenals bij de organisatie van de refereeravonden was je mij ook bij deze promotie altijd zeer behulpzaam, waarvoor mijn uitdrukkelijke dank!

Drs. Lauretta Vaassen en drs. David Koper, paranimfen: Het verheugde mij zeer dat jullie instemden om mij, tijdens de verdediging van dit proefschrift, bij te staan. Hartelijk dank hiervoor! 
急な依頼にも関わらず、本の表・裏表紙をデザインしてくれた小山慶介さんに 深く感謝いたします。心から御礼申し上げます。

[Keisuke Koyama: Voor het op bijzonder korte termijn ontwerpen van de omslag van dit proefschrift; zéér veel dank!]

Stafartsen: Cornelia, Auke en Eric: Dank voor jullie wijze raad en steun tijdens het promotietraject. Dank ook voor het feit dat jullie taken van mij hebben overgenomen zodat ik meer tijd aan deze promotie kon besteden.

Drs. Veronique Timmer: Dank voor je ondersteuning tijdens dit promotietraject.

Ok assistenten: Audrey, Romy en Sophie: Jullie hebben met veel enthousiasme naast mij gestaan, me geholpen en gemotiveerd. Jullie hebben zelfs een ok-set naar mij genoemd, een ware eer! Dank voor jullie inzet.

Alle medewerkers van de polikliniek en het secretariaat van de afdeling Mondziekten, Kaak- en Aangezichtschirurgie van het MUMC+: Dank voor jullie interesse en support die ik dagelijks van jullie ontving.

Julius en Tobias, beste broers: Jullie staan bij (bijna) alles wat ik doe achter mij en zijn mijn klankbord als ik het even niet meer weet. De manier waarop wij elkaar steunen en respecteren is het bewijs dat familie onvervangbaar is. Masami natuurlijk geldt dit ook voor jou.

Mama, Du bist und bleibst das Fundament unserer Familie. Ich bin dir sehr dankbar für alles, was du, zusammen mit Papa, mir und meinen Brüdern gegeben hast. Noch immer bist du jederzeit bereit uns zu unterstützen und zu helfen. Seit Papa's Tod hast du es auf bewundernswerte Art alleine getan. Jeder Versuch, meine Dankbarkeit an dieser Stelle in Worte zu fassen, würde Dir nicht gerecht werden. 


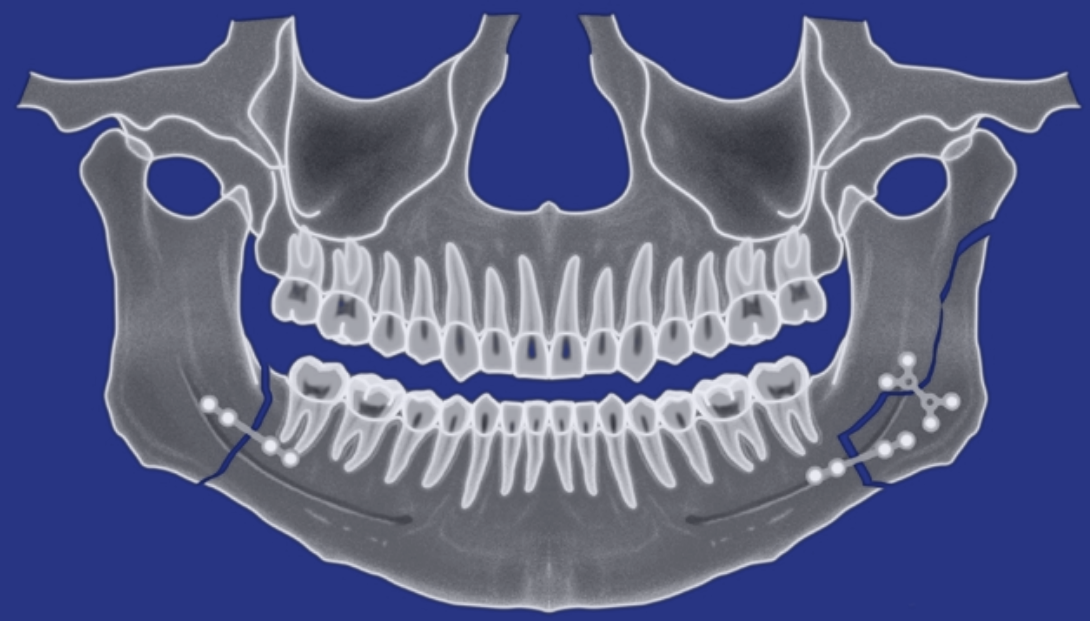

